\title{
NUTRITIONAL CHANGE DUE TO CLIMATE WARMING: AN ANALYSIS OF FATTY ACID CONTENT OF PASTURE PLANTS COMMON TO SOUTHERN ONTARIO
}

\author{
By \\ Emily Morris \\ Bachelor of Science Honours, 2016, Queen's University
}

\author{
A thesis presented to \\ Ryerson University \\ in partial fulfillment of the \\ requirements for the degree of \\ Master of Science \\ in the Program of Molecular Science
}

Toronto, Ontario, Canada

(C) Emily Morris 2018 


\section{AUTHOR'S DECLARATION}

I hereby declare that I am the sole author of this thesis. This is a true copy of the thesis, including any required final revisions, as accepted by my examiners.

I authorize Ryerson University to lend this thesis to other institutions or individuals for the purpose of scholarly research.

I further authorize Ryerson University to reproduce this thesis by photocopying or by other means, in total or in part, at the request of other institutions or individuals for the purpose of scholarly research.

I understand that my thesis may be made electronically available to the public. 


\begin{abstract}
Nutritional Change Due To Climate Warming: An Analysis of Fatty Acid Content of Pasture Plants Common to Southern Ontario

Master of Science

2018

Emily Morris

Molecular Science
\end{abstract}

Climate change will produce a wide range of challenges for grassland ecosystems, including increased global surface air temperature. Increased temperature can increase cell membrane fluidity in plants and other organisms; a response known as homeoviscous adaptation. However, this phenomenon has not been extensively studied in grassland plant species and has not been widely observed in plants from a climate warming perspective. I exposed seven species of agricultural forage plants to a temperature gradient consistent with climate change estimates for Southern Ontario. I compared relative fatty acid composition between temperature conditions, paying particular attention to the relative content of saturated, monounsaturated, and polyunsaturated fatty acids, and essential fatty acids. For most species, I found saturated fatty acid content decreased with increasing temperature, while polyunsaturated fatty acid content and essential fatty acid content increased with increasing temperature. My thesis provides insights into the effects of climate warming on pasture ecosystems. 


\section{ACKNOWLEDGEMENTS}

Firstly, I would like to thank my supervisors, Michael Arts and Lesley Campbell, for their guidance and advice throughout the course of this project. I am especially grateful for them sharing their depth of scientific knowledge with me and for their many helpful revisions during the writing process of this thesis. This project was funded by the NSERC Discovery Grants awarded to both Michael and Lesley. Seeds for this project were kindly donated by Quality Seeds in Vaughan, Ontario.

I would also like to say thank you to my committee member, Richard Bazinet, for taking the time to attend my meetings and always providing insightful suggestions for this project. Thank you to Janet Koprivnikar for being part of my examining committee and to Andrew Laursen for providing support in statistical analysis.

Thank you to Curtis Maloley and the rest of the Learning and Teaching Office staff for helping me realize my love for teaching, as well as providing me an outlet to build my teaching skills and experience. Your guidance has been so valuable for my personal and professional development and for that, I am very grateful.

Huge thanks go out to my "Master's support team": Keira McKee, Kruti Shukla, Tarn Preet Parmar, Dino Milotic and Saif Al Alul. Thank you all for helping me navigate graduate school life and for always offering your help and support. I also need to thank Bryn Hazlett and Bonnie Syme (my "undergraduate support team") for providing jokes and advice via group chat - it was much appreciated!

The biggest thank you goes out to Garret Cree for always being there for me and being my biggest cheerleader for the past eight years, but especially during my Master's degree. You are the best. Finally, thank you to the rest of my friends and family for always believing in my abilities and supporting my career decisions. 


\section{Table of Contents}

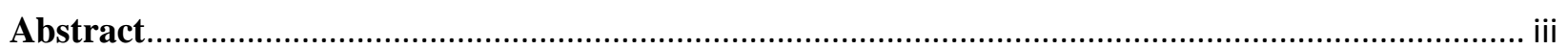

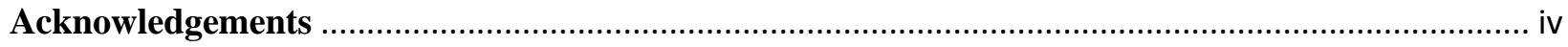

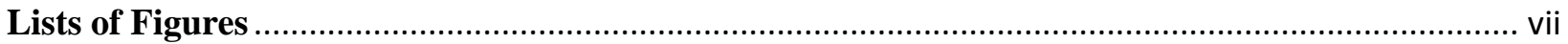

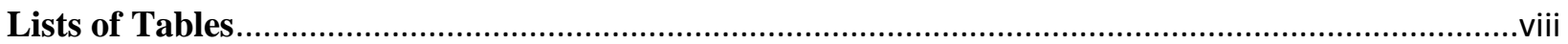

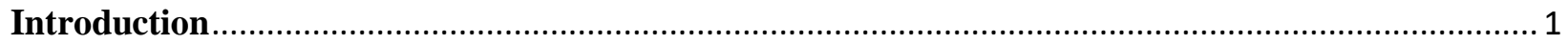

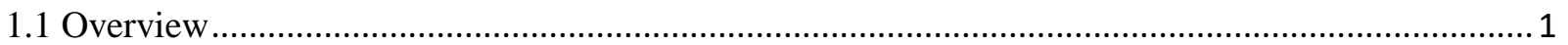

1.2 Global climate warming and its impact in Southern Ontario....................................................... 1

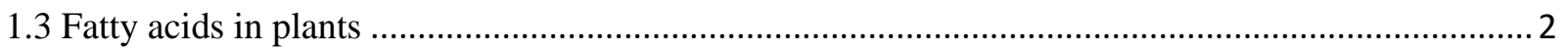

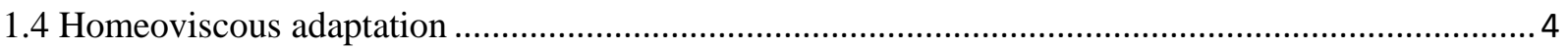

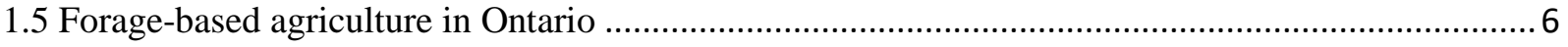

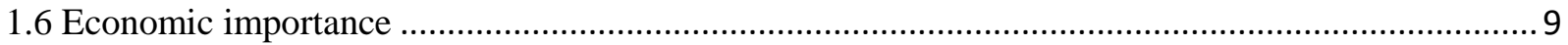

1.7 Managing the risk of altered food webs as a result of climate warming ........................................ 10

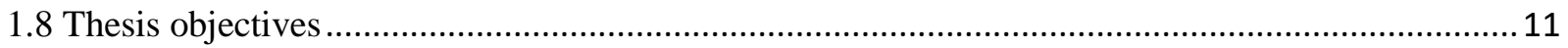

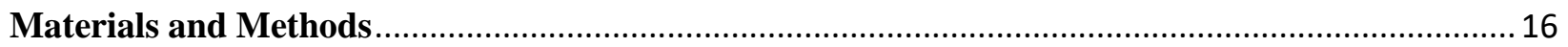

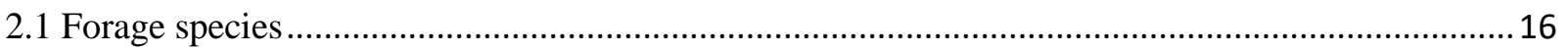

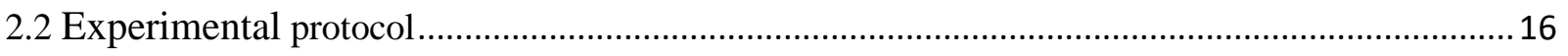

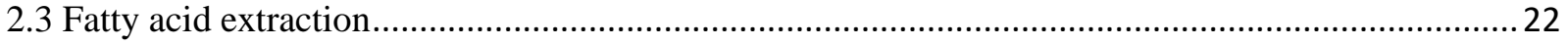

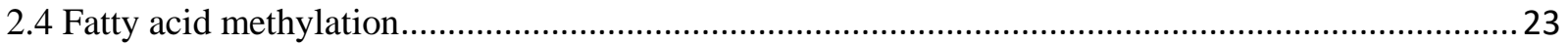

2.5 Gas chromatography analysis and fatty acid quantification........................................................24

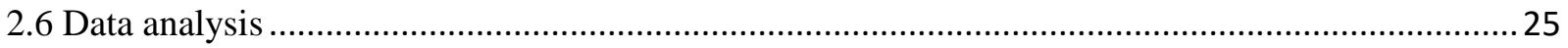

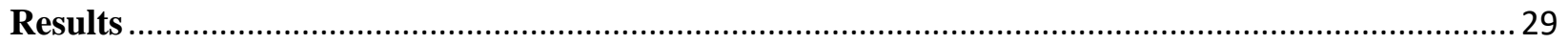

3.1 Does increasing temperature affect plant development and growth? ..........................................29

3.2 Do temperature increases affect saturated, monounsaturated, and polyunsaturated fatty acid content

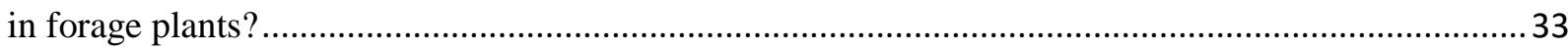

3.3 Does increasing temperature affect the relative amount of major plant fatty acids? ......................40

3.4 Does increasing temperature have an effect on the overall unsaturation index in plants?...............49

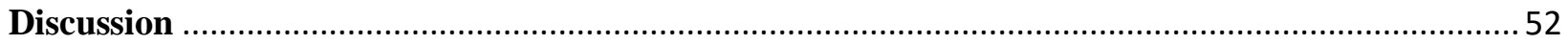

4.1 Effects of temperature on fatty acid content and profile ….........................................................52

4.2 Why does temperature have an effect on fatty acid content and profile of forage plants? ..............55

4.3 Implications for agriculture and ecosystem dynamics in Southern Ontario ..................................57

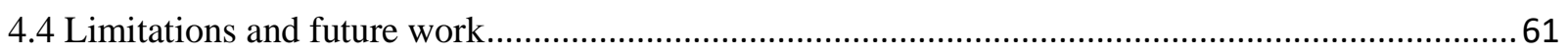

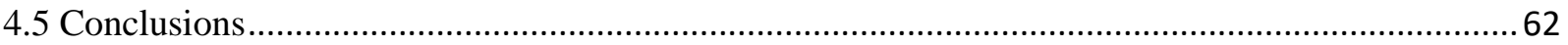




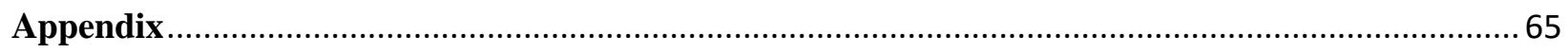

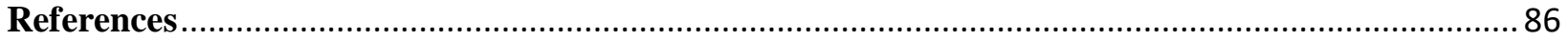




\section{LISTS OF FIGURES}

Fig. 1.1: Representation of the fatty aicd synthesis pathway in plants

Fig. 2.2: Representation of the experimental design, exhibiting "current-ambient" and "futurewarmed" chambers of two sequential experiments,

Fig. 3.1: The relationship between temperature and (a) average days to two-leaf phase $( \pm 95 \%$ confidence interval), (b) wet mass (mg) ( $\pm 95 \%$ confidence interval), and (c) dry mass (mg) $( \pm 95 \%$ confidence interval) for seven plant species ( $\mathrm{N}=18$ per species).

Fig. 3.2: Percent by dry weight content of (a) significant saturated fatty acid trends and (b) nonsignificant saturated fatty acid data as a function of temperature $(\mathrm{N}=18$ per species).......

Fig. 3.3: Percent by dry weight content of (a) significant monounsaturated fatty acid trends and (b) non-significant monounsaturated fatty acid data as a function of temperature ( $\mathrm{N}=18$ per species).

Fig. 3.4: Percent by dry weight content of (a) significant polyunsaturated fatty acid trends and (b) non-significant polyunsaturated fatty acid data as a function of temperature ( $\mathrm{N}=18$ per species).

Fig. 3.5: The ratio of saturated fatty acid/polyunsaturated fatty acid of seven plant species as a function of temperature ( $\mathrm{N}=18$ per species) with (a) significant trends and (b) non-significant data.

Fig. 3.6: Percent content of (a) significant 15:0 trends and (b) non-significant 15:0 data as a function of temperature ( $\mathrm{N}=18$ per species).

Fig. 3.7: Percent content of (a) significant 16:0 trends and (b) non-significant 16:0 data as a function of temperature ( $\mathrm{N}=18$ per species).

Fig. 3.8: Percent content of (a) significant 18:0 trends and (b) non-significant 18:0 data as a function of temperature ( $\mathrm{N}=18$ per species).

Fig. 3.9: Percent content of (a) significant 18:1n-9c trends and (b) non-significant 18:1n-9c data as a function of temperature $(\mathrm{N}=18$ per species).....

Fig. 3.10: Percent content of (a) significant alpha-linolenic acid trends and (b) non-significant alpha-linolenic acid data as a function of temperature ( $\mathrm{N}=18$ per species).

Fig. 3.11: Percent content of (a) significant linoleic acid trends and (b) non-significant linoleic acid data as a function of temperature ( $\mathrm{N}=18$ per species).

Fig. 3.12: Unsaturation index, based on percent by dry weight fatty acid content of (a) significant trends and (b) non-significant data as a function of temperature ( $\mathrm{N}=18$ per species).

Figure 4.1: A comparison of average alpha-linolenic acid content (\% by weight $\pm 95 \%$ confidence interval) of pasture Poaceae species $(\mathrm{N}=107)$ and pasture Fabaceae species $(\mathrm{N}=36)$ - as observed in these trials - versus fodder Poaceae species $(\mathrm{N}=24)$ and fodder Fabaceae $(\mathrm{N}=59)$ species. 


\section{LISTS OF TABLES}

Table 1.1: Descriptions of common fatty acids found in plants .......................................................... 12

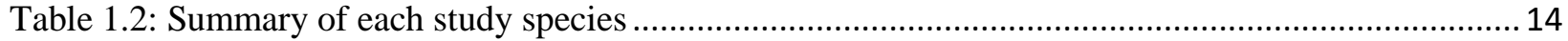

Table 1.3: Summary of economic value in Canada of the forage species chosen for this experiment. ...... 15

Table 2.1: Average percent by dry weight content ( $\pm 95 \%$ confidence interval) for six major plant fatty acids found in various Poaceae and Fabaceae species................................................................ 16

Table 2.2: The average shelf temperature for the "current-ambient" and "future-warmed conditions" of each experiment.

Table 2.3: Summary of the location of 18 weather stations in Southern Ontario used to determine the "current-ambient" and "future-warmed" temperature conditions for the third week of April...

Table 2.4: List of reference fatty acids (i.e., those which could be quantified using NuChek 68E standard curve) and corresponding inferred fatty acids (i.e., fatty acids not present in NuChek $68 \mathrm{E}$ that were quantified using the standard curves of reference fatty acids).

Table 2.5: Common names, scientific names, and fatty acid formulas of 33 fatty acids considered in the analysis of temperature and growth effects

Table 3.1: A comparison of temperatures in a single growth chamber with six shelves that supported the fatty acid experiment that was run four times

Table 3.2: Linear and quadratic regression analyses for the relationship between temperature and development (number of days to reach two-leaf phase), wet mass (mg), and dry mass (mg) of seven plant species.

Table 3.3: Linear, quadratic, and cubic regression analyses for the relationship between temperature and saturated, monounsaturated, and polyunsaturated fatty acids of seven plant species...... 35

Table 3.4: Linear, quadratic, and cubic regression analyses for the relationship between temperature and saturated fatty acid/polyunsaturated fatty acids of seven plant species.

Table 3.5: Linear, quadratic, and cubic regression analyses for the relationship between temperature and 15:0, 16:0, 18:0, 18:1n-9c, alpha-linolenic acid, and linoleic acid of seven plant species

Table 3.6: Linear, quadratic, and cubic regression analyses for the relationship between temperature and unsaturation index of seven plant species. 


\section{Introduction}

\subsection{Overview}

In this thesis, I examine the effects of temperature on common pastureland forage species from a global warming perspective. I introduce the concepts of homeoviscous adaptation, fatty acid (FA) content and profile in response to environmental temperature (as reflected by the various Representative Concentration Pathway (RCP) scenario models developed to predict the surface air temperature (SAT) changes caused by global warming). Specifically, I discuss these concepts in terms of forage plants (i.e., plant species commonly used in livestock pastures), as this is an area that has not been rigorously studied in the scientific community. I test the hypothesis that increased temperature - specifically an average increase of $4.0^{\circ} \mathrm{C}$ - will have an effect on the FA profile of seven forage plant species that are ubiquitous in Southern Ontario's cattle pastures and are thus also often encountered by wild herbivores. I predict that I will see an increase in saturated fatty acid (SFA) content and a decrease in monounsaturated fatty acid (MUFA) and polyunsaturated fatty acid (PUFA) content in most species as temperature increases. However, I also predict that temperature-adapted species (i.e., species typically grown in an unpredictable climate) will show less of an effect as they are likely to be more adapted to increased temperatures. I discuss the implications of the relationship between the FA profile of different plant species and temperature (ranging from $8.0-14.0^{\circ} \mathrm{C}$ ), and how this may impact herbivores, pastureland ecosystem dynamics, and climate change risk assessment.

\subsection{Global climate warming and its impact in Southern Ontario}

The 2014 Intergovernmental Panel on Climate Change (IPCC) predicts a temperature increase of between $1.0-6.0^{\circ} \mathrm{C}$ in Southern Ontario relative to mean annual pre-industrial SAT by the year 2100 . Within the IPCC report, there are four proposed climate models, incorporating a range of greenhouse gas emission scenarios, which predict the global increase in SAT as a result of global warming within the next 100 years. These RCP scenario models were developed by a team of IPCC scientists who took into account the global uncertainty associated with greenhouse gas emissions and climate change (Hibbard et al. 2007, Moss et al. 2010). Therefore, the possible outcomes of climate change and human activity (i.e., adaptation and mitigation efforts) were combined to produce the RCP scenario models (Moss et al. 2010). Representative concentration pathway 2.6 is a best-case scenario and assumes an immediate peak in greenhouse gas emissions, inferring a relatively quick curtailing of emissions due to reduced carbon use and improved technological solutions and thus predicts a modest $1.0^{\circ} \mathrm{C}$ increase in SAT. In contrast, RCP 
8.5 predicts a $3.7^{\circ} \mathrm{C}$ increase in SAT under the assumption that there will be continually high greenhouse gas emissions in the coming years (i.e., this represents a worst-case scenario). Finally, RCP 4.5 and 6.0 models rely on intermediate emission scenarios and predict intermediate SAT increases $\left(1.8\right.$ and $2.2^{\circ} \mathrm{C}$, respectively).

There are also geography-specific models developed by Canadian federal research scientists, which predict anticipated changes in SAT in various regions of Canada over the next 80 years. Based on the average SAT patterns in Canada between 1950-2010 and the information provided by the RCP scenarios, Environment and Climate Change Canada (ECCC) predicted slightly different SAT increases than the global estimates for three RCP scenario models: RCP $2.6\left(+1.4^{\circ} \mathrm{C}\right)$, RCP $4.5\left(+2.6^{\circ} \mathrm{C}\right)$, and RCP $8.5\left(+6.0^{\circ} \mathrm{C}\right.$ ) (Warren and Lemmen 2014, ECCC 2016). These SAT increase scenarios represent the spring and summer months (the time period most relevant to the growth of forage grasses in Canada).

Finally, based on the combined data from the 2014 IPCC and 2016 ECCC reports, Southern Ontario (i.e., latitude $41^{\circ} 59^{\prime} 56.396^{\prime \prime}$ to $45^{\circ} 30^{\prime} 50.2098^{\prime \prime} \mathrm{N}$ and longitude $74^{\circ} 23^{\prime} 40.7893^{\prime \prime}$ to $83^{\circ} 4^{\prime}$ $6.2286 " \mathrm{~W})$ can expect to see two extremes of global warming projections. The lesser of the two extremes is a predicted $1.0^{\circ} \mathrm{C}$ increase within the next 100 years in the spring and summer months; assuming all human greenhouse gas use peaks immediately (based on IPCC data for RCP 2.6 in Ontario). The worse of the two scenarios is a $6.0^{\circ} \mathrm{C}$ increase under the highest predicted emission levels during the spring and summer months within the next 100 years (based on ECCC data for RCP 8.5 in Ontario). Therefore, it can be concluded that Southern Ontario is likely to experience anywhere between a 1.0 and a $6.0^{\circ} \mathrm{C}$ increase in SAT within the next 100 years. This broad scale environmental change will affect ecosystem dynamics in Southern Ontario, especially for ectothermic organisms, including plants, which rely on physiological responses to adapt to changes in the ambient temperature of their surrounding environment.

\subsection{Fatty acids in plants}

Fatty acids are a group of molecules characterized as carboxylic acids consisting of a hydrocarbon chain and a terminal carboxyl group (COOH) (Erwin 1973). When classifying different FA, four things are taken into account: the number of carbons in the hydrocarbon chain, the total number of double bonds, the position of the first double bond from the methyl end of the molecule, and whether the double bond is in the cis- or trans-configuration (where cis-conformation is the most common form found in nature). Saturated FA have no double bonds in their hydrocarbon chain, and so every carbon is fully saturated with hydrogens (Erwin 1973, Ernst et al. 2016). Monounsaturated FA have one double bond in 
their hydrocarbon tail, while PUFA have two or more double bonds in their hydrocarbon tail (Erwin 1973, Ernst et al. 2016). The position of the first double bond is important, as it can affect the structure and stability of the FA molecule (Capella and Zorzut 1968, Nichols et al. 1986). An omega-3 FA (also called an n-3 FA) has its first double bond at the third carbon from the methyl end of the molecule, while an omega-6 FA (also called an n-6 FA) has its first double bond at the sixth carbon from the methyl end. Fatty acids serve as building blocks for other compounds (i.e., cell membrane lipids, energy storage lipids) or they can be broken down in a process called lipid metabolism (i.e., the gradual lipolysis of FA into acetyl CoA molecules, which feed into the Krebs cycle) to produce the ATP required to fuel an organism's energy requirements (Randle et al. 1963, Harwood 1988).

Plants are primary producers that occupy the base of food chains and use the sun's energy to produce biochemicals, like FA, that are required for survival and maintenance (Lindeman 1942, Chapin III et al. 1996). Plants produce many different types of FA with a variety of chemical properties in terms of carbon length, level of saturation, and position of double bonds (Table 1.1). The FA profile of terrestrial plants is generally high in palmitic acid (16:0) (Malainey et al. 1999, Barros et al. 2010, Prada et al. 2011), oleic acid (18:1n-9) (Hassan et al. 2011, Teixeira et al. 2012, Santos et al. 2013), and linoleic acid (LNA; 18:2n-6) (Pascual-Villalobos and Alburquerque 1996, Malainey et al. 1999, Bogucka-Kocka and Janyszek 2010), and relatively low in stearic acid (18:0) (Vazquez-Ocmin et al. 2010, Nguyen et al. 2015) and $\alpha$-linolenic acid (ALA; 18:3n-3) (Orhan et al. 2009, Silva et al. 2014, Marchand et al. 2016, Morris et al. 2018, unpublished). However, the FA composition may vary depending on species and environmental factors. Some species of plants contain less common FA, such as nervonic acid (24:1n-9) (Dembitsky and Rezanka 1995, Makarenko et al. 2003, Ozcan 2008) and the n-3 FA stearidonic acid (18:4n-3) (Johansson et al. 2000, Freije et al. 2013). The distinctness of the FA composition of plants serves various physiologically important purposes not only for the individual plant that produces them, but also for many herbivores and ultimately, for humans, that directly or indirectly depend on these plants.

There are two FA types that vertebrates can only obtain from their diet. These two FA are therefore called essential fatty acids (EFA) and refer to ALA (n-3 FA) and LNA (n-6 FA) (Burr and Burr 1929, Burr and Burr 1930, Holman 1971). While vertebrates cannot synthesize ALA and LNA, plants and some invertebrate taxa are able to produce them (through specific desaturase enzymes which insert a double bond at the n-3 or n-6 position) and thus provide sources of these EFA to primary and secondary consumers (Bogucka-Kocka and Janyszek 2010, Orhan et al. 2009, Silva et al. 2014, Marchand et al. 2016, Kabeya et al. 2018). This means that plants contribute to maintaining the health of ecosystems from 
a FA perspective (Arts et al. 2003). In vertebrates, ALA, stearidonic acid (SDA), and LNA act as precursors for even more crucial FA, such as eicosapentaenoic acid (EPA; 20:5n-3) and docosahexaenoic

acid (DHA; 22:6n-3), and arachidonic acid (ARA; 20:4n-6), respectively (Menard et al. 1998, Bazinet and Laye 2014). Overall, there are two terrestrial plant species that have been documented to produce EPA (yam and leek) and two terrestrial plant species that have been documented to produce DHA (fennel and jelly palm) (Morris et al. 2018, unpublished). Eicosapentaenoic acid is associated with the health and maintenance of the cardiovascular system in vertebrates (Li et al. 1997, Sargent et al. 1998), while DHA and ARA confer benefits for vertebrate brain development and maintenance (Neuringer et al. 1986, Simopoulos 1991, Murthy et al. 2002, Rao et al. 2007, Bazinet and Laye 2014). Additionally, DHA often obtained through breast milk in early development - is especially important for vertebrate visual acuity (Birch et al. 1998, Birch et al. 2010); human infants that are breast-fed experience accelerated development of visual acuity in the first year of growth (Hoffman et al. 2004).

Plants are at the base of terrestrial food webs and in this position they are often a large source of many essential nutrients (including EFA) for herbivores (e.g., livestock, deer, insects etc.) (Elser et al. 2000, Wardle et al. 2004). In addition, if the FA composition of plants change, it will generally be reflected in the FA composition of herbivore flesh and milk (Sanders 2000, Bazinet et al. 2003, Wood et al. 2008) and therefore reflected in secondary consumers, as well (Milligan and Bazinet 2008). For example, it has been observed that long-chain PUFA (i.e., EPA and DHA), when consumed by herbivores, readily cross the blood-brain barrier and are incorporated into brain tissue (Ouellet et al. 2009). Therefore, any perturbation in a plant's nutrient composition, particularly from a FA perspective, is likely to be expressed in consumers owing to the retention of EFA in agricultural food webs (Glasser et al. 2008).

\section{$\underline{1.4 \text { Homeoviscous adaptation }}$}

Fatty acids serve a multitude of roles in terrestrial plants that are generally defined by their physical structure (Quinn and Williams 1983, Bonaventure et al. 2003, Zheng et al 2005). In terrestrial plants, FA production begins with palmitic acid and/or oleic acid as precursors (Ohlrogge and Browse 1995) (Fig. 1.1). The hydrocarbon tail of these FA can then be elongated (through addition of carbon and hydrogen) and activated polar headgroups are added to produce glycerolipids and triacylglycerols (Ohlrogge and Browse 1995). Glycerolipids are the most common lipid group found in plant cells (Ohlrogge and Browse 1995) and play an important role in the structural integrity of plants as part of cell membranes (Jouhet et al. 2006). The FA content of glycerolipids in the cell membrane of forage plants 
will depend on environmental conditions (Roessler 1990, Shimojima and Ohta 2011, Zheng et al. 2011) but is generally composed of palmitic, palmitoleic, stearic, oleic, ALA, and LNA phospholipids (Millar et al. 2000, Clapham et al. 2005). Triacylglycerols (TAG) serve a different role than glycerolipids as they constitute a type of energy storage molecule and so they are typically found in high quantities in seeds and fruits but low quantities in leaves, stems, and roots (Bao and Ohlrogge 1999, Lung and Weselake 2006). Triacylglycerols in forage plants is generally composed of palmitic, stearic, oleic acids, ALA, and LNA (Mattson and Volpenhein 1963, Brough et al. 1996, Deineka et al. 2002, Honfo et al. 2014). Therefore, FA content will differ within a plant depending both on the type of lipid and the environmental conditions.

Overall, plants biosynthesize FA at a rate of $\sim 1.0-2.0 \mu \mathrm{mol}$ of $\mathrm{FA} / \mathrm{h} / \mathrm{mg}$ of chlorophyll (Browse et al. 1981, Post-Beittenmiller et al. 1992). Cheesbrough et al. (1989) observed a decrease in FA biosynthesis rates in soybean (Glycine max) as temperature was gradually increased by $10.0^{\circ} \mathrm{C}$. Rate of desaturation may also differ in response to temperature; rate of desaturation has been seen to decrease as temperature increases over a wide range of temperatures in multiple plant species (Harris and James 1969a, Harris and James 1969b, Heppard et al. 1996, Menard et al. 2017). Glycerolipids are more sensitive to changes in temperature than TAG due to their role in the maintenance of structural integrity of plant cell membranes (Iba 2002). As temperature decreases, the plant cell membrane becomes relatively rigid and therefore the relative composition of glycerolipids is dominated by ALA (Wu et al. 2000, Khan et al. 2012). Conversely, as temperature increases, the SFA content generally rises in plant cell membranes and the relative concentration of MUFA and PUFA decreases to offset the increased membrane fluidity as a result of increased temperature (Los et al. 2013, Szymanski et al 2014, Li et al. 2016). This phenomenon is known as homeoviscous adaptation, which is a biochemical remodeling of already-existing FA in the cell membrane in response to changes in environmental temperature (Sinensky 1974). Specifically, when temperature increases, enzymes used to synthesize PUFA are down regulated but when temperature decreases these same enzymes are up regulated and more PUFA are produced (Behrouzian and Buist 2002, Nozawa 2011, Ernst et al. 2016, Saunders et al. 2016). Unsaturated FA have a lower melting point than SFA and thus exist in a more fluid form (Arts and Kohler 2009); unsaturated FA also have increased flexibility due to the presence of double bonds (Feller et al. 2001). Therefore, the removal of unsaturated FA from the membrane occurs when temperatures are increased beyond optimal levels in an organism. This phenomenon was observed in plants when three varieties of Arachis hypogaea (i.e., peanut) experienced a temperature increase of $\sim 2.0^{\circ} \mathrm{C}$ in a natural environment over the course of three years and the FA content of seeds was measured; SFA increased by $\sim 2.0 \%$, MUFA decreased by $4.0 \%$, and PUFA decreased by between 0.03 and $0.5 \%$ (Onemli 2012). Pearcy (1978) observed similar 
patterns in SFA, MUFA, and PUFA content when comparing a single species of saltbush (Atriplex lentiformis) grown at ambient temperatures $\left(23.0^{\circ} \mathrm{C}\right)$ versus warmed temperatures $\left(43.0^{\circ} \mathrm{C}\right)$. Similarly, Asclepias procera (a species of milkweed) showed increased SFA and decreased MUFA and PUFA content in plants that were grown in warm climates versus ambient climates with only a difference of $2.0^{\circ} \mathrm{C}$ (Barbosa et al. 2014). Taken in a global context, this relationship between FA remodeling and temperature may result in the alteration of relative composition of FA in terrestrial plants as the earth continues to warm due to climate change. This pattern has also been observed in marine and freshwater phytoplankton, where meta-analysis determined that, across 952 FA profiles, changes in FA content occurred with increasing temperature along the range of 0.0 to $40.0^{\circ} \mathrm{C}$ (Hixson and Arts 2016). Based on what is known about plant membrane fluidity responses to increased temperature, climate warming could result in higher concentrations of SFA and lower concentrations of MUFA and PUFA within some plant species (particularly those adapted to live in cooler climates).

\subsection{Forage-based agriculture in Ontario}

Forage plants are often neglected in the scientific literature with regards to FA composition. This may be due to their generally low total lipid content (Vioque et al. 1994, Bogucka-Kocka and Janyszek 2010, Yang et al. 2012) compared to oil-rich crops, such as flax and nuts (Baydar 2004, Correa and Atehortua 2012). However, the importance of identifying the FA composition of pasture plants - and the factors that may affect these FA, namely temperature - should not be underestimated. Pasture plants are the main sources of FA for livestock and wild herbivores (Mir et al. 2006). However, the FA composition in plants has been seen to be affected by temperature, typically showing increased SFA and decreased PUFA content with increasing temperature (Pearcy 1978, Onemli, 2012, Barbosa et al. 2014). Therefore, it is important to document and quantify the effect of temperature on pasture plants to predict the health and nutrition of herbivores as climate warming progresses.

The Ontario Ministry of Agriculture, Food, and Rural Affairs (OMAFRA) provides farmers with a number of forage plant recommendations to facilitate successful forage agriculture in Ontario (OMAFRA 2015). I selected seven species of interest for this project based on a range of qualities (Table 1.2). Kentucky bluegrass (Poa pratensis) and orchardgrass (Dactylis glomerata) were selected for their ubiquity in Southern Ontario pastoral agriculture. Kentucky bluegrass is widely used - both domestically and in agriculture - because it is a lush grass species it has aesthetic benefits but also provides a soft treading surface for grazing livestock (OMAFRA 2015). Orchardgrass is widespread in agriculture because it establishes quickly and is high yielding (Eagles 1983, Jafari and Naseri 2007). Smooth 
bromegrass (Bromus inermis), tall fescue (Festuca arundinacea), white clover (Trifolium repens), and alfalfa (Medicago sativa) were selected for their high yield and digestibility (i.e., these species are high in carbohydrates and proteins but low in fiber) (Terry and Tilley 1964, Jung and Vogel 1986, Julier and Huyghe 1997). Perennial ryegrass (Lolium perenne) was selected for its potential temperature sensitivity; this species has exhibited an inability to survive hot and dry conditions (Xu et al. 2006, Lee et al. 2007, OMAFRA, 2015). All species are classified as $\mathrm{C}_{3}$ plants (i.e., carbon dioxide capture and Calvin cycle occur in a single cell) as these are the plants species typically used in Southern Ontario agriculture (Wand et al. 1999). Alfalfa and white clover are dicotyledon species (i.e., produce two cotyledons), while the rest are monocotyledon species (i.e., produce one cotyledon). Alfalfa and white clover are also both legumes, meaning that, through their symbiotic association with common soil bacterium (Rhizobium spp. which invades the roots of leguminous plants forming a nodule), they are able to convert atmospheric nitrogen into a usable form of nitrogen (i.e. nitrate) in the soil (Ledgard and Steele 1992, Zahran 1999). They have similar life cycles, as they are both perennial $\mathrm{C}_{3}$ plants. It was important that each temperature treatment include a dicotyledon species, as these are widely used in agriculture and have shown less pronounced responses to temperature than monocotyledon species (Poire et al. 2010). Thus, white clover was selected for the first temperature manipulation experiment and alfalfa for the second.

The species used in this study are considered cool-season temperate plants (Bunger et al. 2012), which means the temperature for optimal growth ranges from 10 to $30^{\circ} \mathrm{C}$ and the day-to-day environmental conditions are typically wide-ranging, especially with respect to temperature (i.e., $10-15^{\circ} \mathrm{C}$ differences) (Berry and Bjorkman 1980, Jiang and Huang 2001, Liu and Huang 2003). This is in contrast with warm-season tropical plants, where the day-to-day temperatures remain relatively consistent (i.e., 1$2^{\circ} \mathrm{C}$ differences) (Lough 1995). These environmental differences are reflected in the lipid composition of temperate versus tropical plants. Temperate plant species have shown overall higher total lipid content than tropical plants species (Sanyal and Decocq 2016, Susanto et al. 2016). The individual FA composition of temperate and tropical plants may differ, as well. Although 16:0, 18:0, and 18:1n-9c fatty acids show consistent levels across north temperate, north tropical, south temperate, and south tropical latitude regions, ALA and LNA content show large differences (Morris et al. 2018, unpublished). North temperate plants have the highest average levels of ALA ( 15\%) while south temperate plants exhibit the highest average levels of LNA ( $50 \%)$, as compared to north and south tropical plants (Appendix 5.8). This may be an adaptive strategy in order to maintain resilience during fluctuating temperatures in temperate environments (Zheng et al. 2011). 
Despite structural differences, all forage plant species are most digestible for livestock during the decimal code (i.e., growth scale identifying various plant developmental stages) stages 11 to 13 (i.e., from the first true leaf to the third true leaf) (Kilcher and Troelson 1972, Kilcher 1981). As they age, forage plants become gradually less nourishing, more fibrous and more difficult for livestock to digest (Manske 2000, Nousiainen et al. 2002, Saleem et al. 2009). Additionally, the proportion of total lipid in leaves decreases in pasture plants as they age, with all other variables remaining constant (Dutta and Appelqvist 1991, Hellgren and Sandelius 2001, Clapham et al. 2005, Mishra et al. 2006). When comparing 15-dayold seedlings to more mature 42-day-old plants of Arabidopsis, Yurchenko et al. (2017) observed increases in LNA and decreases in ALA with age. This same pattern was observed in millet (Goossen et al. 2018). Other individual FA, such as 18:0 and 18:1n-9c did not change in terms of relative composition with age (Yurchenko et al. 2017). When comparing the milk of ewes fed either early-season pasture plants or mature pasture plants, the sheep consuming the early season plants produced more milk that was higher in protein content (Addis et al. 2005). Therefore, I chose early-stage plants (i.e., plants at the twoleaf stage) to be study organisms as this is when grazing begins and the plants are at their peak of nutrition.

Typically, in Southern Ontario, farmers begin sowing new seeds and maintaining the perennial species of their pastures in April, and by June they begin allowing their livestock to graze (Majak et al. 1995, Lyons et al. 2000, Contant et al. 2001, J. Thoman [Farmer Jim's Grass-fed Beef] and C. Young [Harmony Organic Dairy Products Inc.], pers. comm., 2016). During this two-month period, seeds will germinate and reach the vegetative stages of growth, producing anywhere between one and three true leaves (Moore et al. 1991, Gustavsson 2011). These stages of development are ideal for livestock grazing as grasses are at their peak of digestibility. Interestingly, these stages are also the most sensitive to environmental changes, as growth rate slows in response to decreased temperature (Moore et al. 1991, Manske 2000, Saleem et al. 2009). Prairie grass and tall fescue were observed to have decreased growth rates at temperature extremes i.e. either colder $\left(15.0^{\circ} \mathrm{C}\right)$ or warmer $\left(24.0^{\circ} \mathrm{C}\right)$ relative to optimal growth temperatures (i.e., $18.0-21.0^{\circ} \mathrm{C}$ ) (Hill et al. 1985). This same pattern was observed in various dicotyledon genera, including Trifolium and Plantago, where growth rate slowed in response to extreme low temperatures (Chapman et al. 1983, Loveys et al. 2002). Depending on the state of greenhouse gas emissions in the coming years, pastures in Southern Ontario may experience an SAT increase of between 1.0 and $6.0^{\circ} \mathrm{C}$ during the most influential growth stages of these forage plants (i.e., April-June). Because this increase in SAT will occur during the vegetative stages of growth, the nutrient composition and general structure of forage grasses may be affected. This, in turn, could influence the health of pasturelands and subsequently primary and secondary consumers as part of the agricultural food web. 
Sustained exposure to elevated temperatures (i.e., over the period of many weeks at a time) has potential to affect the growth and fatty acid content of common pasture species in Southern Ontario. Long-term exposure to elevated temperatures has caused earlier flowering and increased levels of primary productivity in grassland ecosystem plants (Cleland et al. 2006, Tubiello et al. 2007). However, this level of productivity may not be sustainable, as Shaw et al. (2002) observed decreased growth in grassland plants exposed to elevated temperatures over the course of two years. Sustained heat may have implications for fatty acid content as well; Canvin (1964) observed a continual decrease in total lipid content in flax and rapeseed plants that were exposed to $26.5^{\circ} \mathrm{C}$ (versus $10.0^{\circ} \mathrm{C}$ ) temperatures for a number of weeks. In this same study, sunflower, safflower, and castor bean plants held in $26.5^{\circ} \mathrm{C}$ environments had less PUFA and more 18:1n-9c than the plants grown at $10.0^{\circ} \mathrm{C}$ (Canvin 1964). Therefore, long-term exposure to elevated temperatures as a result of climate warming may change the productivity and fatty acid content of primary producers.

\section{$\underline{1.6 \text { Economic importance }}$}

Canada has a strong and vibrant agricultural economy. In Canada, forage plants and pastures currently occupy $\sim 40.0 \%$ of land dedicated to crop production, generating $>30,000,000$ metric tonnes of forage in 2015 (Bonnefield Research 2016). More specifically, in Ontario in 2016, 4,000,000 metric tonnes encompassing $\sim 30,500,000$ ha of forage grass were harvested, worth $>\$ 700,000,000$ (McCartney and Horton 1997, OMAFRA 2017). As research exploring the benefits of forage-fed livestock over grainfed livestock intensifies (Robinson 2002, Floris et al. 2006, Howes et al. 2014), the impact of forage grass on livestock health and nutritional value is expected to grow in Ontario, and in Canada as a whole (Howes et al. 2014, Russelle et al. 2007, Salc and Tracy 2007). The species chosen for this experiment currently make up substantial portion of the economic value of forage in Canada, summarized in Table 1.3 (Canadian Seed Trade Association 2015).

One of Canada's major exports is meat derived from livestock feeding on forage pastures. However, it is well known that the value of meat can vary based on the nutritional quality of the resulting product. Overall, meat is considered to be of good quality and nutrition when it is high in n-3 unsaturated FA (especially conjugated linoleic acid (CLA) and ALA) and low in SFA (Scollan et al. 2006).

Conjugated linoleic acid is a form of LNA where the two double bonds of the molecule are separated by a single bond between them (Banni 2002); CLA is often found in meat and dairy products (Banni 2002) and may confer health benefits like cancer inhibition in mammals (Ha et al. 1987). These chemical qualities 
improve the flavor and appearance of the meat (Cross et al. 1980, Daley et al. 2010), making it attractive to consumers, and as more people become aware of the connection between diet and nutrition, sales of more nutritious/healthy meat stand to benefit even more economically (Scollan et al. 2006). Conversely, poor meat nutrition can negatively affect a country's gross domestic product, especially if meat is a major export (as is the case in Canada) (Fan and Pandya-Lorch 2012). The nutritional quality of meat products in Canada is ultimately determined by the nutritional quality of Canada's primary producers (i.e., forage plants) (Scollan et al. 2006, Cherfaoui et al. 2013). However, primary producers are susceptible to changes in nutrient composition as a result of a changing environment. Therefore, to ensure a strong economic system in the face of environmental change, it is important to consider the nutritional composition of forage plant species that constitute the base of the animal husbandry industry.

\subsection{Managing the risk of altered food webs as a result of climate warming}

If there is potential for the FA composition of forage plants to change as a result of global climate warming, there then exists the subsequent potential for the FA composition in herbivores to change. The FA composition of vertebrates is highly influenced by the diet (Burr and Burr 1930, Kris-Etherton et al. 2000, Dalsgaard et al. 2003, Blondeau et al. 2015), as animals do not possess the enzymes required to produce ALA and LNA from FA precursors (i.e., 16:0 and 18:0) (Barcelo-Coblijn and Murphy 2009), but can synthesize EPA, DHA, and ARA, albeit at low efficiencies, if ALA or SDA, and LNA, respectively, are included in the diet (Cunnane et al. 1993, Brenna et al. 2009). Pasture feeding with plants that are rich in ALA and LNA has been seen to promote the incorporation of LNA into livestock milk (Robinson 2002, Floris et al. 2006) as well the overall level of n-3 FA in meat and milk (Howes 2014). It has also been observed that animals fed diets high in ALA produce similar levels of DHA in their adipose tissue to those fed diets high in direct sources of DHA (Domenichiello et al. 2015). These patterns may be temperature-dependent since researchers have found decreased n-3 FA levels in the meat and milk of livestock during warmer months (Mel'uchova et al. 2008), perhaps due the substitution of these FA from plant cell membranes in response to temperature (Howes 2014). This trend may continue as climate warming progresses, resulting in progressively less nutritious meat and milk products.

If the predicted changes in FA composition of plants and herbivores do occur in future years, there could be serious implications for herbivore health in Southern Ontario. There is some evidence that unsaturated FA, particularly long chain n-3 PUFA, may provide a range of health benefits in vertebrates, including improved cardiovascular health (Krauss et al. 2000, Mozaffarian and Wu 2011, Endo and Arita 2016), respiratory health (Singer et al. 2006), and brain development and maintenance (Yu et al. 1986, 
Amminger et al. 2012). Decreased levels of the precursors (ALA, SDA, LNA) of these vital nutrients as a result of climate warming effects on forage plants thus have the potential to change pastureland ecosystem dynamics. Specifically, a diet high in PUFA improves overall digestion in ruminants and contributes to the maintenance of healthy fertility in livestock (Santos et al. 2013). Therefore, it is important to understand and evaluate the effect of temperature on the FA composition of common forage plants, particularly with regard to climate warming.

From a risk assessment perspective, it is important to tease apart the effect of SAT on different forage plant species to allow farmers, seed supply companies, agricultural management organizations, and policymakers to effectively adapt to climate warming. Some plant species may be more resistant to temperature changes than others (in terms of FA content), and if I can identify these species, I will be able to advise farmers about the ideal species to use in pastures in the climate-warmed future. If I find decreased incidence of unsaturated FA, with warming, in some forage plant species, then an appropriate response might be to reduce seeding of those particular species in Ontario pastures. Similarly, if I find unchanged or increased unsaturated FA content in certain species, then Ontario farmers may be advised to respond by seeding these species more frequently in their pastures as climate warming progresses.

\section{$\underline{1.8 \text { Thesis objectives }}$}

Here I examine the response of the FA content and composition of seven forage plants to changes in SAT in line with projected global warming models for Southern Ontario. I address the following research questions:

1. Do temperature increases affect SFA, MUFA, and PUFA content in commonly seeded forage plants in Ontario?

2. Do individual FA in plants respond to increases in temperature?

3. Does increasing temperature have an effect on the overall unsaturation index in plants?

4. Does increasing temperature affect the growth rate and size of pasture plants?

Based on the phenomenon of homeoviscous adaptation, I predict that increased temperature will reduce MUFA and PUFA content - and thus unsaturation - in most species and that it will increase the SFA content in most species, but temperature-adapted species will show less of an effect than species that are adapted to growing in cooler temperatures. I also predict that individual FA will respond to increases in temperature in line with the type of FA (SFA, MUFA or PUFA). My research findings contribute to a 
decision-making tool for farmers and policymakers in the future to adapt to the effects of climate warming through use of the most environmentally robust and nutrient-rich pasture species as determined by these experimental trials.

Table 1.1: Descriptions of common FA found in plants

\begin{tabular}{|c|c|c|c|c|}
\hline Common name & $\begin{array}{c}\text { Fatty acid } \\
\text { formula }\end{array}$ & Carbon length & Type of fatty acid & $\begin{array}{l}\text { Position of first } \\
\text { double bond* }\end{array}$ \\
\hline Palmitic acid & $16: 0$ & 16 & Saturated & $\mathrm{n} / \mathrm{a}$ \\
\hline Stearic acid & 18:0 & 18 & Saturated & $\mathrm{n} / \mathrm{a}$ \\
\hline Oleic acid & $18: \ln -9$ & 18 & Monounsaturated & 9 \\
\hline Linoleic acid (LNA) & $18: 2 n-6$ & 18 & Polyunsaturated & 6 \\
\hline$\alpha$-linolenic acid (ALA) & ALA & 18 & Polyunsaturated & 3 \\
\hline Stearidonic acid & $18: 4 n-3$ & 18 & Polyunsaturated & 3 \\
\hline Nervonic acid & $24: 1 n-9$ & 24 & Monounsaturated & 9 \\
\hline
\end{tabular}

*from the methyl end of the molecule 


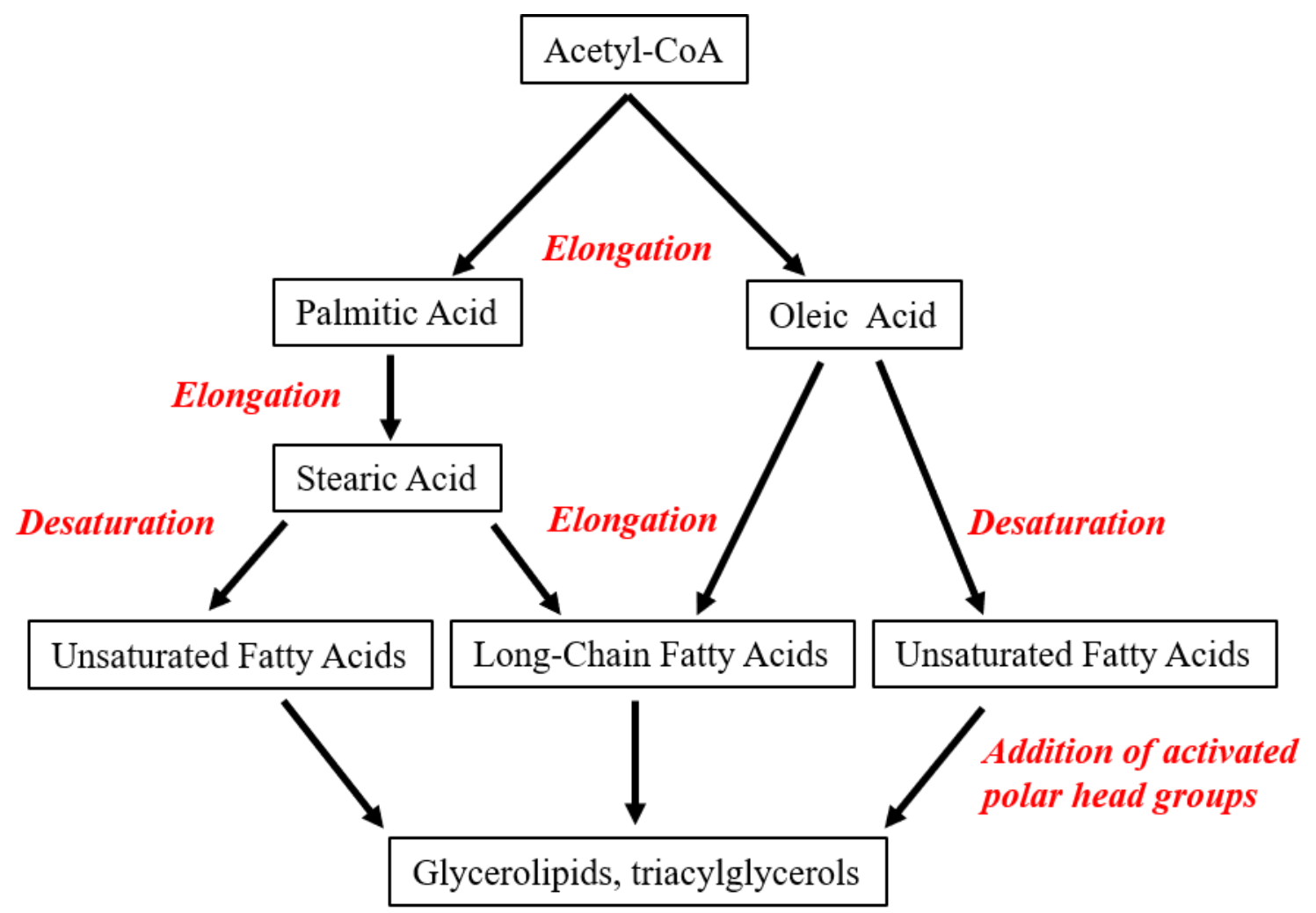

Fig. 1.1: Representation of the FA synthesis pathway in plants (Ohlrogge and Browse 1995, Thelen and Ohlrogge 2002). 
Table 1.2: Summary of each study species: life cycle, where annual plants survive only one growing season whereas perennial plants survive for many growing seasons; plant structure, where monocotyledon species germinate with one cotyledon whereas dicotyledon species germinate with two cotyledons; origin, where native refers to species that occur naturally in North America and introduced refers to non-native species brought to North America by humans; and typical geographic range, which describes the locations in which each species is typically found.

\begin{tabular}{|c|c|c|c|c|c|}
\hline Scientific name & Common name & Life cycle & Plant structure & Origin & $\begin{array}{c}\text { Typical geographic } \\
\text { range }\end{array}$ \\
\hline Poa pratensis $\mathrm{L}$. & Kentucky bluegrass & Annual & Monocot & Native & Globally widespread \\
\hline Dactylis glomerata L. & Orchardgrass & Perennial & Monocot & Introduced & North America \\
\hline Bromus inermis Leyss. & Smooth bromegrass & Perennial & Monocot & Introduced & $\begin{array}{c}\text { Western U.S.A. and } \\
\text { Canada }\end{array}$ \\
\hline $\begin{array}{c}\text { Festuca arundinacea } \\
\text { Schreb. }\end{array}$ & Tall fescue & Perennial & Monocot & Introduced & Globally widespread \\
\hline Medicago sativa $\mathrm{L}$. & Alfalfa & Perennial & Dicot & Introduced & Globally widespread \\
\hline Trifolium repens L. & White clover & Perennial & Dicot & Introduced & Globally widespread \\
\hline Lolium perenne L. & Perennial ryegrass & Perennial & Monocot & Native & Globally widespread \\
\hline
\end{tabular}


Table 1.3: Summary of economic value in Canada of the forage species chosen for this experiment.

\begin{tabular}{cc}
\hline \hline Species & $\begin{array}{r}\text { Economic value in Canada } \\
\text { (annual \$ for 2014) }\end{array}$ \\
\hline Kentucky bluegrass & $3,743,000$ \\
Orchardgrass & 54,000 \\
Smooth bromegrass & 166,000 \\
Tall fescue & 909,000 \\
Alfalfa & $5,874,000$ \\
White clover & 514,000 \\
Perennial ryegrass & $5,225,000$ \\
& \\
\hline
\end{tabular}




\section{Materials and Methods}

\section{$\underline{2.1 \text { Forage species }}$}

Based on information from OMAFRA (Pasture Production, 2015), several forage grass and legume species were considered for this experiment: Kentucky bluegrass (Poa pratensis), orchardgrass (Dactylis glomerata), perennial ryegrass (Lolium perenne), white clover (Trifolium repens), smooth bromegrass (Bromus inermis), tall fescue (Festuca arundinacea), and alfalfa (Medicago sativa). White clover and Kentucky bluegrass seeds were obtained from Speare Seeds (Harriston, Canada). Seeds of the remaining species were obtained from Quality Seeds (Vaughan, Canada). The providence of seeds was unknown but may have consequences for the plastic response of plants. Average content of six major FA types in Poaceae (Kentucky bluegrass, orchardgrass, perennial ryegrass, smooth bromegrass, tall fescue) and Fabaceae (white clover, alfalfa) are presented in Table 2.1 (Morris et al. 2018, unpublished).

Table 2.1: Average percent by dry weight content $( \pm 95 \%$ CI $)$ for six major FA found in various Poaceae and Fabaceae species (Morris et al. 2018, unpublished).

\begin{tabular}{ccccccc}
\hline \hline Plant family & $\mathbf{1 5 : 0}$ & $\mathbf{1 6 : 0}$ & $\mathbf{1 8 : 0}$ & $\mathbf{1 8 : 1 n - 9 c}$ & ALA & LNA \\
\hline Poaceae & $0.32 \pm 0.01$ & $15.62 \pm 2.24$ & $3.98 \pm 4.45$ & $16.27 \pm 2.94$ & $5.03 \pm 1.68$ & $49.52 \pm 6.72$ \\
Fabaceae & $0.18 \pm 0.06$ & $13.39 \pm 1.73$ & $3.47 \pm 0.65$ & $20.23 \pm 3.27$ & $12.83 \pm 4.27$ & $34.63 \pm 5.08$ \\
\hline
\end{tabular}

\subsection{Experimental protocol}

First, to approximate temperature conditions of a recent average Ontario spring, I calculated an average spring temperature from the average temperatures of 18 Canadian weather stations (Table 2.2) in Southern Ontario (latitude $42^{\circ} 53^{\prime} 00.000^{\prime \prime}$ to $44^{\circ} 15^{\prime} 56.000^{\prime \prime} \mathrm{N}$ and longitude $79^{\circ} 05^{\prime} 00.000^{\prime \prime}$ to $80^{\circ} 45^{\prime} 00.000 " \mathrm{~W}$ ) during the month of April (the month in which forage seedlings in Southern Ontario are establishing) (Government of Canada Environment and Natural Resources). The range of temperatures experienced by these stations during the month of April was $\sim-2.0^{\circ} \mathrm{C}$ at the coldest and $\sim 21.0^{\circ} \mathrm{C}$ at the warmest. These weather stations were chosen because they were located within a $150 \mathrm{~km}$ radius of Toronto, Ontario, and encompassed a large area of agricultural operation in Southern Ontario (the area that my study aimed to inform). To best represent typical weather from the 18 locations, the average recorded daytime high temperature between the years 1980-2016 was used to generate the "currentambient" day conditions, and the average recorded nighttime low temperature between the years 1980- 
2016 generated the "current-ambient" night conditions (Government of Canada Environment and Natural Resources, WeatherSpark). Each station reported a daytime length of $\sim 14 \mathrm{~h}$, where sunrise to sunset was typically 6:00 AM to 8:00 PM (Government of Canada Environment and Natural Resources).

The following protocol was carried out sequentially in a single growth chamber, resulting in two experiments each with two identical temperature treatments (Fig. 2.2). The two target temperature treatments were imposed on plants from germination to harvest: 1) a "current-ambient" calculated from Environment Canada weather data $\left(11.3^{\circ} \mathrm{C}\right.$ day $/ 2.5^{\circ} \mathrm{C}$ night $)$; and 2) a "future-warmed" which added $4.0^{\circ} \mathrm{C}$ to the "current-ambient" conditions $\left(15.3^{\circ} \mathrm{C}\right.$ day $/ 6.5^{\circ} \mathrm{C}$ night $)$. The "future-warmed" treatment temperatures were assigned based on intermediate estimates (RCP 4.5 and 6.0) by the IPCC (2014) and ECCC (2005) reports for Southern Ontario, which collectively predict an increase of $\sim 2.0-5.0^{\circ} \mathrm{C}$ due to climate warming. Each temperature treatment experienced a photoperiod of $14 \mathrm{~h}$ light:10 h dark, which is typical for the third week of April in Southern Ontario (Government of Canada Environment and Natural Resources, WeatherSpark). Therefore, the photoperiod was consistently $14 \mathrm{~h}$ day:10 h night across treatments and the "future-warmed" treatment was $4.0^{\circ} \mathrm{C}$ warmer than the "current-ambient" treatment for both experiments. 
Experiment 1

Current Ambient

\begin{tabular}{|c|}
\hline Shelf 1 \\
Species $1 \times 9$ \\
Species $2 \times 9$ \\
Species $3 \times 9$ \\
Species $4 \times 9$ \\
\hline Shelf 2 \\
Species $1 \times 9$ \\
Species $2 \times 9$ \\
Species $3 \times 9$ \\
Species $4 \times 9$ \\
\hline Shelf 3 \\
Species $1 \times 9$ \\
Species $2 \times 9$ \\
Species $3 \times 9$ \\
Species $4 \times 9$ \\
\hline
\end{tabular}

Future Warmed

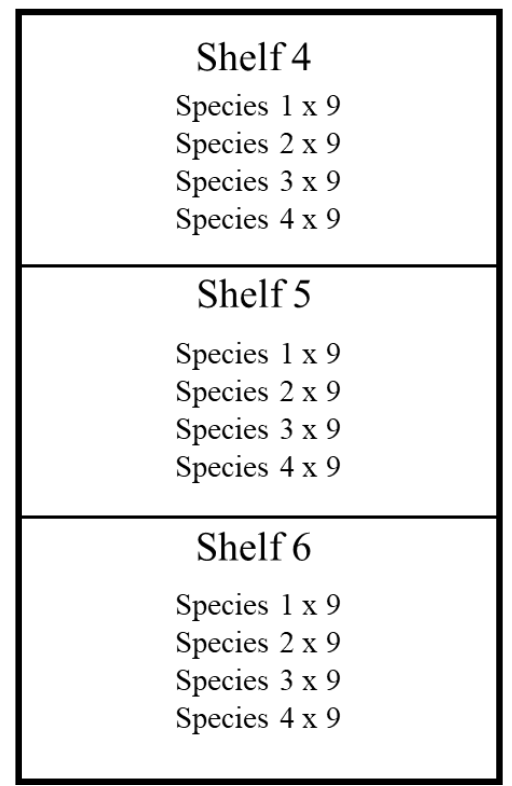

\section{Experiment 2}

Current Ambient

\begin{tabular}{|c|}
\hline Shelf 1 \\
Species $4 \times 9$ \\
Species $5 \times 9$ \\
Species $6 \times 9$ \\
Species $7 \times 9$ \\
\hline Shelf 2 \\
Species $4 \times 9$ \\
Species $5 \times 9$ \\
Species $6 \times 9$ \\
Species $7 \times 9$ \\
\hline Shelf 3 \\
Species $4 \times 9$ \\
Species $5 \times 9$ \\
Species $6 \times 9$ \\
Species $7 \times 9$ \\
\hline
\end{tabular}

Future Warmed

\begin{tabular}{|c|}
\hline Shelf 4 \\
Species $4 \times 9$ \\
Species $5 \times 9$ \\
Species $6 \times 9$ \\
Species $7 \times 9$ \\
\hline Shelf 5 \\
Species $4 \times 9$ \\
Species $5 \times 9$ \\
Species $6 \times 9$ \\
Species 7 7 ×9 \\
\hline Shelf 6 \\
Species $4 \times 9$ \\
Species 5 59 \\
Species $6 \times 9$ \\
Species 7 $7 \times 9$ \\
\hline
\end{tabular}

Fig. 2.2: Representation of the experimental design, exhibiting "current-ambient" and "future-warmed" chambers of two sequential experiments, three shelves within the chamber (shelves 1-3 for "current-ambient" treatment and shelves 4-6 for "future-warmed" treatment) and seven species with nine replicate individuals within each shelf (species 1-7). Experiment 1 grew species 1-4 and Experiment 2 grew species 4-7. 
Increasing the breadth of temperature-response data, two experiments were run in sequence, so seven forage plant species could be observed. Species were divided such that each experiment contained species with similarities. For example, white clover (Experiment 1) and alfalfa (Experiment 2) are both dicotyledon species; orchardgrass (Experiment 1) and tall fescue (Experiment 2) have both been recognized for their high productivity (OMAFRA 2015); Kentucky bluegrass (Experiment 1) and smooth bromegrass Experiment 2) are both used ubiquitously across Southern Ontario (OMAFRA). Both experiments used perennial ryegrass as a species of references between trials. Species in each experiment were grown all at once.

To ensure seeds had sufficient access to water, ten seeds of each species were planted at depths of $0.5 \mathrm{~cm}$ in a "cone-tainer" pot (6.4 cm diameter conical pots; Ray Leach model \#SC10U, Tangent, U.S.A.) using Premier Tech Potting Soil (sphagnum, peat, perlite, humus; 1:1:1:1), a nutrient-rich, sterile soil type. The pots were then placed in a Variable Temperature Diurnal Incubator (VWR International model \#2015, Mississauga, Canada). To maintain consistency across all samples, after the first individual emerged, all subsequent seedlings that emerged from the soil were removed from each pot using tweezers.

Measures were taken to maintain monitored conditions within the chamber. Temperature was monitored using three Onset HOBO temperature loggers (Onset \#UTBI-001, Bourne, U.S.A.) placed in the centre of each shelf in the chamber. Humidity was monitored using a single MagnaTemp hygrometer (Canadian Tire Corporation \#042-9471-4, Toronto, Canada) placed on the left wall of the chamber to ensure that relative humidity remained between 30.0-50.0\% throughout the course of the experiment. Seedlings were watered twice per week with $10 \mathrm{~mL}$ of water per pot to ensure that all pots received the same amount of water. Watering did not disrupt the temperature within the incubator. Pot positions within the chamber were randomized and repositioned twice per week to new locations on the same shelf. This was done to eliminate exposure to light as a confounding factor, as the light shone from fluorescent bulbs spanning the height of the chamber, from the front of the chamber, causing a light gradient within the chamber. Light intensity of the two General Electric fluorescent bulbs (Model \#F32T8, Boston, U.S.A.) within the chamber was not measured.

The amount of time (in days) to reach the two-leaf stage (i.e., two leaves fully unfolded) was recorded for each individual (Fig. 2.1). Typically, under ambient temperatures (i.e., $12.5^{\circ} \mathrm{C}$ ), monocotyledon plants take $\sim 15 \mathrm{~d}$ (after emergence) to reach the two-leaf stage while dicotyledon plants take $\sim 13 \mathrm{~d}$ (after emergence) to reach the two-leaf stage (Boyes et al. 2001, Vos et al. 2005). Wet and dry 
above-ground biomass was also measured (in mg; accuracy $\pm 0.40 \mu \mathrm{g}$; precision $\pm 0.80 \mu \mathrm{g}$ ) for each individual using a microbalance (Mettler Toledo \#XP6, Mississauga, Canada). The above-ground biomass was taken (as opposed to below-ground biomass) because this is the part of the plant that is encountered/eaten by herbivores and is therefore most relevant to measuring FA content in grazers that consume the above-ground biomass of plants.

Due to the design of the chamber, each shelf (three shelves total) experienced a unique average temperature (Table 2.3), with the bottom shelf being $\sim 1.5^{\circ} \mathrm{C}$ warmer than the top shelf; therefore, each shelf was treated as an individual independent treatment, nested within "current-ambient" and "futurewarmed" conditions, resulting in a gradient of six different temperatures per experiment (Fig. 2.2). All measurements for each shelf were replicated with nine plants of each species (i.e., nine individuals per species per shelf). The appropriate amount of mass required to produce enough crude FA extract to be detectable by gas chromatography is $10.0-30.0 \mathrm{mg}$ dry weight (Folch et al. 1957). Therefore, all replicates from a given species were then randomly combined in groups of three plants for bulk FA analysis, resulting in three extraction samples per species per shelf.

Table 2.2: The average shelf temperature for the "current-ambient" and "future-warmed conditions" of each experiment; values are reported as the average temperature $\left({ }^{\circ} \mathrm{C}\right) \pm 95 \% \mathrm{CI}$.

\section{Experiment 1}

\begin{tabular}{cccccc}
\hline \multirow{3}{*}{ Current-ambient } & & \multicolumn{3}{c}{ Future-warmed } \\
Shelf 1 & Shelf 2 & Shelf 3 & Shelf 4 & Shelf 5 & Shelf 6 \\
$9.27 \pm 0.09$ & $10.11 \pm 0.10$ & $10.67 \pm 0.11$ & $12.27 \pm 0.12$ & $12.99 \pm 0.13$ & $13.50 \pm 0.15$ \\
\hline \hline \multicolumn{7}{c}{ Current-ambient } & & & Future-warmed & \\
\hline \multirow{2}{*}{ Shelf 1 } & Shelf 2 & Shelf 3 & Shelf 4 & Shelf 5 & Shelf 6 \\
$8.00 \pm 0.09$ & $8.60 \pm 0.09$ & $9.73 \pm 0.11$ & $12.30 \pm 0.09$ & $12.97 \pm 0.09$ & $13.51 \pm 0.10$ \\
\hline
\end{tabular}


Table 2.3: Summary of the location of 18 weather stations in Southern Ontario used to determine the "current-ambient" and "future-warmed" temperature conditions for the third week of April (Government of Canada Environment and Natural Resources, WeatherSpark). From the 18 locations, the average recorded daytime high temperature between the years 1980-2016 was used to generate the "currentambient" day conditions, and the average recorded nighttime low temperature between the years 19802016 generated the "current-ambient" night conditions.

\begin{tabular}{ccc}
\hline \hline Southern Ontario Location & Latitude & Longitude \\
\hline Borden & $44^{\circ} 15^{\prime} 56.000^{\prime \prime} \mathrm{N}$ & $79^{\circ} 55^{\prime} 10.000^{\prime \prime} \mathrm{W}$ \\
Burlington & $43^{\circ} 21^{\prime} 00.000^{\prime \prime} \mathrm{N}$ & $79^{\circ} 48^{\prime} 00.000^{\prime \prime} \mathrm{W}$ \\
Buttonville & $43^{\circ} 51^{\prime} 39.000^{\prime \prime} \mathrm{N}$ & $79^{\circ} 22^{\prime} 07.000^{\prime \prime} \mathrm{W}$ \\
Egbert & $44^{\circ} 14^{\prime} 00.000^{\prime \prime} \mathrm{N}$ & $79^{\circ} 47^{\prime} 00.000^{\prime \prime} \mathrm{W}$ \\
Elora & $43^{\circ} 41^{\prime} 00.000^{\prime \prime} \mathrm{N}$ & $80^{\circ} 24^{\prime} 00.000^{\prime \prime} \mathrm{W}$ \\
Hamilton & $43^{\circ} 16^{\prime} 00.000^{\prime \prime} \mathrm{N}$ & $79^{\circ} 54^{\prime} 00.000^{\prime \prime} \mathrm{W}$ \\
Hamilton & $43^{\circ} 10^{\prime} 18.000^{\prime \prime} \mathrm{N}$ & $79^{\circ} 56^{\prime} 03.000^{\prime \prime} \mathrm{W}$ \\
Lincoln & $43^{\circ} 08^{\prime} 21.000^{\prime \prime} \mathrm{N}$ & $79^{\circ} 29^{\prime} 05.000^{\prime \prime} \mathrm{W}$ \\
Mount Forest & $43^{\circ} 59^{\prime} 00.000^{\prime \prime} \mathrm{N}$ & $80^{\circ} 45^{\prime} 00.000^{\prime \prime} \mathrm{W}$ \\
Niagara Falls & $43^{\circ} 08^{\prime} 00.000^{\prime \prime} \mathrm{N}$ & $79^{\circ} 05^{\prime} 00.000^{\prime \prime} \mathrm{W}$ \\
Port Colborne & $42^{\circ} 53^{\prime} 00.000^{\prime \prime} \mathrm{N}$ & $79^{\circ} 15^{\prime} 00.000^{\prime \prime} \mathrm{W}$ \\
St. Catharines & $43^{\circ} 12^{\prime} 00.000^{\prime \prime} \mathrm{N}$ & $79^{\circ} 15^{\prime} 00.000^{\prime \prime} \mathrm{W}$ \\
St. Catharines & $43^{\circ} 11^{\prime} 30.000^{\prime \prime} \mathrm{N}$ & $79^{\circ} 10^{\prime} 16.000^{\prime \prime} \mathrm{W}$ \\
Stayner & $44^{\circ} 22^{\prime} 00.000^{\prime \prime} \mathrm{N}$ & $80^{\circ} 05^{\prime} 00.000^{\prime \prime} \mathrm{W}$ \\
Toronto & $43^{\circ} 40^{\prime} 00.000^{\prime \prime} \mathrm{N}$ & $79^{\circ} 24^{\prime} 00.000^{\prime \prime} \mathrm{W}$ \\
Toronto & $43^{\circ} 40^{\prime} 36.000^{\prime \prime} \mathrm{N}$ & $79^{\circ} 37^{\prime} 50.000^{\prime \prime} \mathrm{W}$ \\
Toronto & $43^{\circ} 41^{\prime} 00.000^{\prime \prime} \mathrm{N}$ & $79^{\circ} 16^{\prime} 14.900^{\prime \prime} \mathrm{W}$ \\
Waterloo & $43^{\circ} 27^{\prime} 39.000^{\prime \prime} \mathrm{N}$ & $80^{\circ} 22^{\prime} 43.000^{\prime \prime} \mathrm{W}$ \\
\hline
\end{tabular}




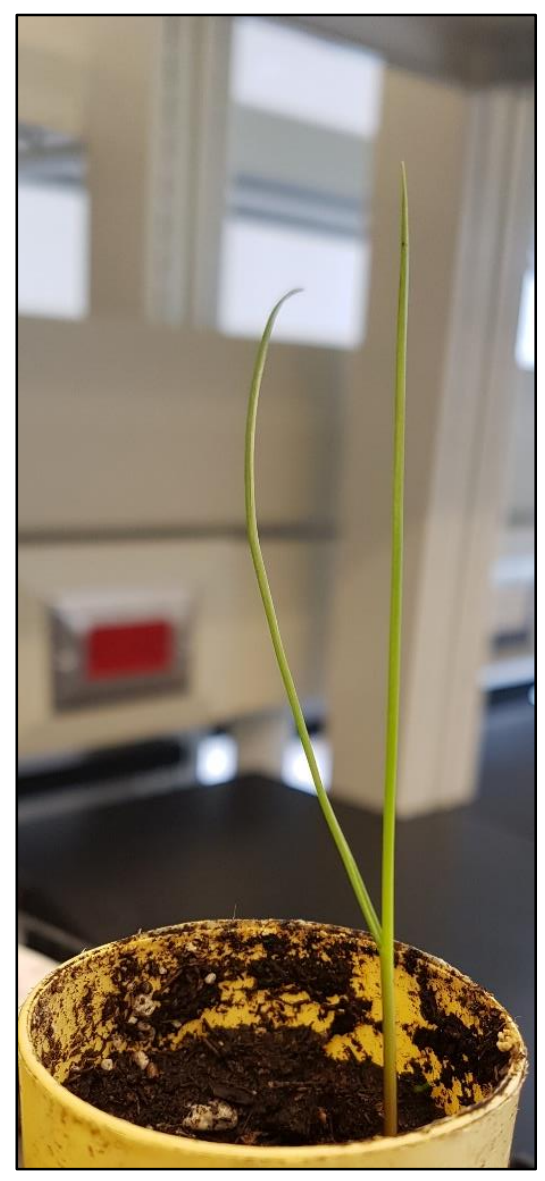

Fig. 2.1: Example of perennial ryegrass seedling at the two-leaf phase, where both leaves are fully unfolded and $\sim 3.0 \mathrm{~cm}$ long.

\subsection{Fatty acid extraction}

Each individual sample was weighed immediately after harvest to obtain the wet mass of the entire above-ground biomass. Following weighing, each sample was frozen at $-80.0^{\circ} \mathrm{C}$ for $15 \mathrm{~min}$ and then freeze-dried for $48 \mathrm{~h}$ in a Labconco FreeZone lyophilizer (Labconco Corporation \#7670520, Kansas City, U.S.A.). Samples were re-weighed to obtain dry mass and ground into a fine powder in using an agate mortar and pestle into which a small amount of liquid nitrogen was added. All tissue samples were stored at $-80.0^{\circ} \mathrm{C}$.

Each bulk sample was extracted according to a modified Folch et al. (1957) method. Briefly, ground samples were combined in a culture tube with $4 \mathrm{~mL}$ of $2: 1$ chloroform:methanol and $20 \mu \mathrm{L}$ of both a 17:0 and 22:3n-3 FA internal standard (at 0.0025 mg/mL; NuChekPrep, Elysian, U.S.A.). To each 
sample, $0.8 \mathrm{~mL}$ of $0.88 \% \mathrm{KCl}$ solution was added and then this solution was centrifuged at $2000 \mathrm{RPM}$ for 5 min at $4.0^{\circ} \mathrm{C}$. The bottom layer (chloroform:methanol:water [86:14:1] layer) was collected and placed in a new tube. To the original tubes, $2 \mathrm{~mL}$ of 86:14:1 chloroform:methanol:water was added and this procedure was repeated once more. The new tubes containing the chloroform:methanol:water solution were dehydrated under an $\mathrm{N}_{2}$ stream, leaving only lipids behind. Following dehydration, $2 \mathrm{~mL}$ of hexane was added and gravimetric analysis was performed to obtain an estimate of the total lipid content; $100 \mu \mathrm{L}$ of hexane solution was added to tin cups, allowed to evaporate, and weighed (subtracting the weight of each tin cup).

\subsection{Fatty acid methylation}

To each sample, $2 \mathrm{~mL}$ of $\mathrm{H}_{2} \mathrm{SO}_{4}$ in methanol (1\% v/v) was added (Sheppard and Iverson 1975, Liu 1994). All samples were then placed on a heat block at $90.0^{\circ} \mathrm{C}$ for $90 \mathrm{~min}$. Samples were removed from heat and allowed to cool to room temperature; $1.5 \mathrm{~mL}$ of Milli-Q water and $4 \mathrm{~mL}$ of hexane were then added. Each sample was centrifuged at $2000 \mathrm{RPM}$ for $3 \mathrm{~min}$ at $4^{\circ} \mathrm{C}$. The top layer (hexane layer) was decanted and placed in a new tube. To the original tubes, $4 \mathrm{~mL}$ of hexane was added and this process was repeated twice. Samples were then dehydrated under an $\mathrm{N}_{2}$ stream to dryness and $400 \mu \mathrm{L}$ of hexane was added as the final volume for analysis. The entire solution was then transferred to gas chromatography (GC) vials and sealed using crimp tops. 
2.5 Gas chromatography analysis and fatty acid quantification

Gas chromatography (Shimadzu GC-2010 Plus, Kyoto, Japan) was used to identify and then quantify the FA content of each sample. The initial column temperature was $60^{\circ} \mathrm{C}$ and was gradually increased to $250^{\circ} \mathrm{C}$ over a period of $37 \mathrm{~min}$. The samples were then held at $250^{\circ} \mathrm{C}$ for $23 \mathrm{~min}$. A chromatogram was produced, where each peak was identified using NuChek GLC463 FA standard (NuChekPrep, Elysian, U.S.A.). Fatty acid content ( $\mu \mathrm{g} / \mathrm{mg}$ DW and percent composition) was then calculated by generating a standard curve using four concentrations of NuChek 68E FA standard (NuChekPrep, Elysian, U.S.A). Curve intercepts were forced through zero to ensure FA values were not extrapolated as negative contents. Some FA in this analysis could not be directly quantified using the NuChek 68E standard, and so the standard curves of similar FAs (with similar chemical structure) were applied (outlined in Table 2.4). Unsaturation index was calculated (UI; FA content*number of double bonds summed for each identified FA in a sample) to observe the effect of temperature on the overall saturation level in a sample.

Table 2.4: List of reference FA (i.e., those which could be quantified using NuChek 68E standard curve) and corresponding inferred FA (i.e., FA not present in NuChek $68 \mathrm{E}$ that were quantified using the standard curves of reference FA).

Reference FA

15:0

$15: \ln -5$

$16: 1 \mathrm{n}-7 \mathrm{t}$

$17: 1 \mathrm{n}-7$

$18: 1 \mathrm{n}-9 \mathrm{t}$

$18: 1 \mathrm{n}-7 \mathrm{t}$

19:0

$18: 2 \mathrm{n}-6 \mathrm{t}$

$18: 3 n-6$

20:1n-15

20:1n-12

$20: 3 n-6$

$22: 2 n-6$

22:4n-6

\section{Corresponding Inferred FA}

$14: 1 n-5$

$16: 1 \mathrm{n}-7 \mathrm{c}$

$16: 1 \mathrm{n}-7 \mathrm{c}$

$18: 1 \mathrm{n}-9 \mathrm{c}$

$18: 1 \mathrm{n}-7 \mathrm{c}$

18:0

$18: 2 n-6 c$

$18: 3 n-3$

20:1n-9

20:1n-9

$20: 3 n-3$

$22: 1 n-9$

$22: 6 n-3$ 


\subsection{Data analysis}

To determine the influence of shelf and replicate on temperature within the chamber, I used a Type 3 ANOVA model, with shelf (shelves 1-6), replicate (experiments 1 and 2) and the interaction between shelf and replicate as fixed effects and temperature as the response variable. Temperature data satisfied the assumptions of normality and homogeneity of variance. The significant effect of replicate was implemented as a random independent variable (versus the fixed effects of chamber and shelf) in MANOVA analysis of perennial ryegrass (Appendix 5.3). Based on ANOVA analysis, it was determined that the fixed effect of species was significant for all response variables examined in this study.

To determine the influence of temperature on growth and development, I developed regression models for each of the seven study species, resulting in three sets of regression models. The first set of models had average shelf temperature (1-6) as a covariate and development (i.e., the time, in days, to reach the two-leaf stage) as a response variable. The second set of models had average shelf temperature (1-6) as a covariate and wet mass (mg) as a response variable. The final set of models had average shelf temperature (1-6) as a covariate and dry mass $(\mathrm{mg})$ as a response variable. Development, wet mass, and dry mass data were log transformed to satisfy the assumptions of normality and homogeneity of variance.

To determine the influence of temperature on SFA, MUFA, PUFA content and the ratio of SFA/PUFA, I developed regression models for each of the seven study species, resulting in four sets of regression models. The first set of models had average shelf temperature (1-6) as a covariate and SFA content (percent by dry weight) as a response variable. The second set of models had average shelf temperature (1-6) as a covariate and MUFA content (percent by dry weight) as a response variable. The third set of models had average shelf temperature (1-6) as a covariate and PUFA content (percent by dry weight) as a response variable. The final set of models had average shelf temperature (1-6) as a covariate and the SFA/PUFA ratio as a response variable. Saturated FA, MUFA, PUFA, and SFA/PUFA ratio data were $\log$ transformed to satisfy the assumptions of normality and homogeneity of variance. Each regression was performed separately using absolute FA value data $(\mu \mathrm{g} / \mathrm{mg} \mathrm{DW})$ and can be found in Appendix 5.4.

To determine the influence of temperature on individual FA, I developed regression models for each of the seven study species, resulting in six sets of regression models (Table 2.5). The first set of models had average shelf temperature (1-6) as a covariate and 15:0 content (percent by dry weight) as a response variable. The second set of models had average shelf temperature (1-6) as a covariate and 16:0 
content (percent by dry weight) as a response variable. The third set of models had average shelf temperature (1-6) as a covariate and 18:0 content (percent by dry weight) as a response variable. The fourth set of models had average shelf temperature (1-6) as a covariate and 18:1n-9c content as a response variable. The fifth set of models had average shelf temperature (1-6) as a covariate and ALA content as a response variable. The final set of models had average shelf temperature (1-6) as a covariate and LNA content as a response variable. The 15:0, 16:0, 18:0, 18:1n-9c, ALA, and LNA content data were log transformed to satisfy the assumptions of normality and homogeneity of variance. Each regression was performed separately using absolute FA value data $(\mu \mathrm{g} / \mathrm{mg} \mathrm{DW})$ and can be found in Appendix 5.4.

To determine the influence of temperature on UI, I developed regression models for each of the seven study species. Each model had average shelf temperature (1-6) as a covariate and UI as a response variable. Unsaturation index data were log transformed to satisfy the assumptions of normality and homogeneity of variance.

As an alternative analytical approach, MANOVA models (using z-score transformed data) were also tested to compare the fixed effects of shelf temperature (1-6) and chamber temperature (i.e., high versus low) on plant growth, FA content, and FA profiles of six plant species (Kentucky bluegrass, orchardgrass, white clover, tall fescue, alfalfa, and smooth bromegrass). Please see Appendix 5.3 for the results of these analyses. Separate MANOVA models (using z-score values) were developed for perennial ryegrass (the species replicated in both experiments), comparing the fixed effects of shelf temperature (16) and chamber temperature (high versus low) and the random effect of replicate (experiments 1 and 2) on plant growth, FA content, and FA profile. Please see Appendix 5.3 the results of these analyses. 
Table 2.5: Common names, scientific names, and FA formulas of 33 FA considered in the analysis of temperature and growth effects; bolded FA were used for individual FA analysis (i.e., because they were above $1.0 \mu \mathrm{g} / \mathrm{mg} \mathrm{DW})$.

\begin{tabular}{|c|c|c|}
\hline Fatty Acid Formula & FA Common Name & Scientific Name \\
\hline 14:0 & myristic acid & tetradecanoic acid \\
\hline $14: 1 n-5$ & myristoleic acid & cis-9-tetradecanoic acid \\
\hline 15:0 & pentadecanoic acid & pentadecanoic acid \\
\hline $15: 1 n-5$ & --- & cis-10-pentadecenoic acid \\
\hline 16:0 & palmitic acid & hexadecanoic acid \\
\hline $16: 1 \mathrm{n}-7 \mathrm{t}$ & trans-palmitoleic acid & 9-trans-hexadecenoic acid \\
\hline $16: 1 \mathrm{n}-7 \mathrm{c}$ & cis-palmitoleic acid & 9-cis-hexadecenoic acid \\
\hline $17: 1 n-7$ & --- & cis-10-heptadecanoic acid \\
\hline 18:0 & stearic acid & octadecanoic acid \\
\hline $18: 1 \mathrm{n}-9 \mathrm{t}$ & trans-elaidic acid & trans-9-octadenoic acid \\
\hline $18: 1 \mathrm{n}-7 \mathrm{t}$ & --- & trans-11-octadecenoic acid \\
\hline 18:1n-9c & cis-elaidic acid & cis-9-octadenoic acid \\
\hline $18: 1 \mathrm{n}-7 \mathrm{c}$ & vaccenic acid & cis-11-octadecenoic acid \\
\hline 19:0 & nonadecylic acid & nonadecanoic acid \\
\hline $18: 2 n-6 t$ & trans-linoleic acid & trans-9,12-octadecadienoic acid \\
\hline $18: 2 n-6 c$ & cis-linoleic acid & cis-9,12-octadecadienoic acid \\
\hline 20:0 & arachidic acid & eicosanoic acid \\
\hline $18: 3 n-6$ & gamma-linolenic acid & 6,9,12-octadecatrienoic acid \\
\hline $20: 1 n-15$ & --- & cis-5-eicosenoic acid \\
\hline
\end{tabular}




\begin{tabular}{ccc}
\hline Fatty Acid Formula & FA Common Name & Scientific Name \\
\hline $20: 1 n-12$ & --- & cis-8-eicosenoic acid \\
$20: 1 n-9$ & gondoic acid & cis-11-eicosenoic acid \\
$\mathbf{1 8 : 3 n - 3}$ & $\boldsymbol{\alpha}$-linolenic acid & $\mathbf{9 , 1 2 , 1 5 - o c t a d e c a t r i e n o i c ~ a c i d ~}$ \\
$20: 2 \mathrm{n}-6$ & eicosadienoic acid & cis-11,14-eicosadienoic acid \\
$22: 0$ & behenic acid & docosanoic acid \\
$20: 3 n-6$ & dihomo-gamma-linolenic acid & cis-8,11,14-eicosatrienoic acid \\
$22: 1 \mathrm{n}-9$ & erucic acid & 13 -docosenoic acid \\
$20: 3 n-3$ & eicosatrienoic acid & $11,14,17$-eicosatrienoic acid \\
$20: 4 n-6$ & arachidonic acid & $5,8,11,14-$-eicosatetraenoic acid \\
$23: 0$ & tricosylic acid & tricosanoic acid \\
$22: 2 n-6$ & docosadienoic acid & cis-13,16-docosadienoic acid \\
$24: 0$ & lignoceric acid & tetracosanoic acid \\
$24: 1 n-9$ & nervonic acid & 15-tetracosanoic acid \\
$22: 4 n-6$ & docosatetraenoic acid & $7,10,13,16$-docosatetraenoic acid \\
\hline
\end{tabular}




\section{Results}

Shelves at the top of the chamber were significantly warmer than shelves at the bottom of the chamber; the warmest shelf (Shelf 6) was $\sim 5.5^{\circ} \mathrm{C}$ warmer than the coldest shelf (Shelf 1) (Table 3.1). Replicate experiments also differed significantly in temperature within the chamber; overall, the shelves in Experiment 1 were $\sim 1.5^{\circ} \mathrm{C}$ warmer than the shelves in Experiment 2. Finally, there was a significant shelf by replicate interaction effect on temperature within the chamber (Table 2.2). Shelf 1 of Experiment 2 was colder than all other shelves in both experiments. Shelf 2 of Experiment 2 was the next coldest shelf, followed by Shelf 1/Experiment 1, Shelf 3/Experiment 2, Shelf 2/Experiment 1, and Shelf 3/Experiment 1. Shelf 4 of Experiment 1 did not significantly differ from Shelf 4 of Experiment 2. Similarly, Shelf 5 of Experiment 1 did not significantly differ from Shelf 5 of Experiment 2, and Shelf 6 of Experiment 1 did not significantly differ from Shelf 6 of Experiment 2. Shelf 6 was warmer than all other shelves in both experiments; Shelf 5 was next warmest followed by Shelf 4 in both experiments.

Table 3.1: A comparison of temperatures in a single growth chamber with six shelves that supported the FA experiment that was run four times. Temperature was measured using Onset temperature loggers.

\begin{tabular}{cccc}
\hline \hline Independent variable & df & F-value & P-value \\
\hline Shelf & 5 & 2802.54 & $<0.0001$ \\
Replicate & 1 & 375.24 & $<0.0001$ \\
Shelf x replicate & 5 & 83.68 & $<0.0001$ \\
\hline
\end{tabular}

\section{$\underline{3.1 \text { Does increasing temperature affect plant development and growth? }}$}

As temperature increased, the time to reach the two-leaf phase, for most species, significantly decreased (Table 3.2, Fig. 3.1a). Kentucky bluegrass, tall fescue, alfalfa, and smooth bromegrass had negative linear slopes, whereas perennial ryegrass increased to maximum development at $\sim 8.5^{\circ} \mathrm{C}$ and then subsequently decreased as temperature increased. The seven species tested ranged (in aggregate) in development between 45.0 and $70.0 \mathrm{~d}$ to the two-leaf phase at the lowest temperature, whereas the same species ranged between 20.0 and $40.0 \mathrm{~d}$ at the highest temperature. Development in orchardgrass, perennial ryegrass, and white clover was best described using a quadratic function and development in Kentucky bluegrass, tall fescue, alfalfa, and smooth bromegrass was best described using a linear function 
with respect to temperature. Thus, temperature was a strong predictor of development for all species $\left(\mathrm{R}^{2}>\right.$ $0.7)$.

As temperature increased, wet mass significantly increased in all species (with the exception of perennial ryegrass and white clover) (Table 3.2, Fig. 3.1b). In perennial ryegrass, wet mass significantly increased until the chamber reached $\sim 11.5^{\circ} \mathrm{C}$ and subsequently decreased as temperature increased. Wet mass ranged between $\sim 10.0$ and $40.0 \mathrm{mg}$ for all species. Temperature was a moderate predictor of wet mass in perennial ryegrass, tall fescue, alfalfa, and smooth bromegrass $\left(\mathrm{R}^{2}=0.3-0.5\right)$ and was a weak predictor in Kentucky bluegrass and orchardgrass $\left(R^{2}<0.3\right)$. As temperature increased, dry mass significantly increased in tall fescue, alfalfa, and smooth bromegrass (Table 3.2, Fig. 3.1c). In perennial ryegrass, dry mass significantly increased until the chamber reached $\sim 11.0^{\circ} \mathrm{C}$ and subsequently decreased with temperature. Dry mass ranged between 0.0 and $10.0 \mathrm{mg}$ for all species. Temperature was a strong predictor of dry mass in perennial ryegrass, tall fescue and smooth bromegrass $\left(\mathrm{R}^{2}>0.5\right)$, and a moderate predictor in alfalfa $\left(\mathrm{R}^{2}=0.48\right)$. Wet mass and dry mass in perennial ryegrass and white clover were best described using a quadratic function and in Kentucky bluegrass, orchardgrass, tall fescue, alfalfa, and smooth bromegrass were best described using a positive linear function. 
Table 3.2: Linear and quadratic regression analyses for the relationship between temperature and development (number of days to reach two-leaf phase), wet mass (mg), and dry mass (mg) of seven plant species. The $\mathrm{R}^{2}$ value refers to the fit of the overall regression model, $\beta_{1}$ to the linear regression coefficient, and $\beta_{2}$ to the quadratic regression coefficient: $\mathrm{ns}=\mathrm{P}>0.05 ; *=\mathrm{P}<0.05 ; * *=\mathrm{P}<0.01 ; * * *=\mathrm{P}<0.001$.

\begin{tabular}{|c|c|c|c|c|c|c|c|c|c|c|c|c|}
\hline \multirow[t]{2}{*}{ Species } & \multicolumn{2}{|c|}{ Development } & \multirow[t]{2}{*}{$\mathbf{R}^{2}$} & \multirow[t]{2}{*}{ df } & \multicolumn{2}{|c|}{ Wet mass } & \multirow[t]{2}{*}{$\mathbf{R}^{2}$} & \multirow[t]{2}{*}{ df } & \multicolumn{2}{|c|}{ Dry mass } & \multirow[t]{2}{*}{$\mathbf{R}^{2}$} & \multirow[t]{2}{*}{ df } \\
\hline & $\boldsymbol{\beta}_{1}$ & $\boldsymbol{\beta}_{2}$ & & & $\beta_{1}$ & $\boldsymbol{\beta}_{2}$ & & & $\beta_{1}$ & $\boldsymbol{\beta}_{2}$ & & \\
\hline Kentucky bluegrass & $-18.25 * * *$ & --- & 0.86 & 1 & $3.32 * *$ & --- & 0.16 & 1 & $1.45^{\mathrm{ns}}$ & --- & 0.021 & 1 \\
\hline Orchardgrass & $0.01^{\mathrm{ns}}$ & $-0.90^{\mathrm{ns}}$ & 0.88 & 2 & $3.35 * *$ & --- & 0.16 & 1 & $1.87^{\mathrm{ns}}$ & --- & 0.05 & 1 \\
\hline Perennial ryegrass & $3.27 * * *$ & $-4.26 * * *$ & 0.72 & 2 & $4.37 * * *$ & $-4.01 * * *$ & 0.33 & 2 & $-7.28 * * *$ & $7.72 * * *$ & 0.50 & 2 \\
\hline White clover & $-2.56^{\mathrm{ns}}$ & $1.52^{\mathrm{ns}}$ & 0.91 & 2 & $-1.36^{\mathrm{ns}}$ & $1.56^{\mathrm{ns}}$ & 0.28 & 2 & $1.49^{\mathrm{ns}}$ & $-1.31^{\mathrm{ns}}$ & 0.56 & 2 \\
\hline Alfalfa & $-24.41 * * *$ & --- & 0.92 & 1 & $6.99 * * *$ & --- & 0.49 & 1 & $6.84 * * *$ & --- & 0.48 & 1 \\
\hline Smooth bromegrass & $19.67 * * *$ & --- & 0.88 & 1 & $5.90 * * *$ & --- & 0.39 & 1 & $4.54 * * *$ & --- & 0.77 & 1 \\
\hline
\end{tabular}


3.2 Do temperature increases affect SFA, MUFA, and PUFA content in forage plants?

In Kentucky bluegrass, tall fescue, and alfalfa, SFA content decreased to a minimum at $\sim 9.5^{\circ} \mathrm{C}$ and increased to a maximum at $12.0^{\circ} \mathrm{C}$ as temperature increased; these relationships were statistically significant (Table 3.3, Fig. 3.2). Overall, alfalfa had 7.5\% more SFA than Kentucky bluegrass and tall fescue, which both showed between 15.0-20.0\% SFA content. Trends in other species (e.g., orchardgrass, white clover, perennial ryegrass, smooth bromegrass) were non-significant. Temperature was a moderate predictor of SFA content in Kentucky bluegrass and tall fescue $\left(\mathrm{R}^{2}=0.3-0.5\right)$ and was a weak predictor in alfalfa $\left(\mathrm{R}^{2}<0.3\right)$. Saturated FA content in Kentucky bluegrass, perennial ryegrass, tall fescue, and alfalfa was best described using a cubic function, in smooth bromegrass was best described using a quadratic function and in orchardgrass and white clover was best described using a linear function.

In Kentucky bluegrass and perennial ryegrass, MUFA content significantly increased to $\sim 11.5^{\circ} \mathrm{C}$ and subsequently decreased, whereas smooth bromegrass significantly decreased in MUFA content to $\sim 11.5^{\circ} \mathrm{C}$ and subsequently increased as temperature increased; these relationships were significant (Table 3.3, Fig. 3.3). Orchardgrass and white clover showed significant linear slopes in MUFA content between 0.20 and -0.75 as temperature increased. White clover had the highest MUFA content (between 5.0$8.0 \%$ ), while Kentucky bluegrass, orchardgrass, and perennial ryegrass all had between 3.0-4.0\% MUFA content. Smooth bromegrass had the lowest overall MUFA content (between 2.0-2.5\%). Temperature was a moderate predictor of MUFA content in white clover $\left(\mathrm{R}^{2}=0.4\right)$ and was a weak predictor in the remaining species $\left(\mathrm{R}^{2}<0.3\right)$. Monounsaturated FA content in tall fescue was best described using a cubic function, in Kentucky bluegrass, perennial ryegrass, and smooth bromegrass was best described using a quadratic function and in orchardgrass, white clover and alfalfa was best described using a linear function. Trends in other species were non-significant.

In tall fescue and alfalfa, PUFA content increased to a maximum at $\sim 9.5^{\circ} \mathrm{C}$ and decreased to a minimum at $12.0^{\circ} \mathrm{C}$ as temperature increased; these relationships were significant (Table 3.3, Fig. 3.4). Kentucky bluegrass increased to a maximum PUFA content at $\sim 10.5^{\circ} \mathrm{C}$ and decreased to a minimum at $12.5^{\circ} \mathrm{C}$ as temperature increased; this relationship was significant. Polyunsaturated FA content increased in smooth bromegrass to $11.5^{\circ} \mathrm{C}$ and subsequently decreased as temperature increased; this relationship was significant. Orchardgrass showed a significant positive linear slope in PUFA content of $\sim 0.5$ and white clover showed a significant positive linear slope of 2.2 as temperature increased. Kentucky bluegrass, orchardgrass, tall fescue, and smooth bromegrass all had PUFA levels between 75.0-80.0\%, 
while alfalfa had lower levels ranging from 67.0-75.0\%. White clover was the most variable in PUFA content, increasing from $\sim 67.0 \%$ to $\sim 77.0 \%$ with temperature. Polyunsaturated FA content in Kentucky bluegrass, perennial ryegrass, tall fescue, and alfalfa was best described using a cubic function, in smooth bromegrass was best described using a quadratic function and in orchardgrass and white clover was best described using a linear function. Temperature was a strong predictor of PUFA content in Kentucky bluegrass and white clover $\left(R^{2}>0.5\right)$, was a moderate predictor in orchardgrass and tall fescue $\left(R^{2}=0.3\right.$ $0.5)$ and was a weak predictor in alfalfa and smooth bromegrass $\left(\mathrm{R}^{2}<0.3\right)$. Trends in other species were non-significant.

Alfalfa decreased to a minimum SFA/PUFA ratio at $\sim 9.5^{\circ} \mathrm{C}$ and increased to a maximum at $12.0^{\circ} \mathrm{C}$ as temperature increased, while Kentucky bluegrass decreased to a minimum SFA/PUFA ratio at $10.5^{\circ} \mathrm{C}$ and increased to a maximum at $12.5^{\circ} \mathrm{C}$ as temperature increased; these relationships were significant (Table 3.4, Fig. 3.5). In tall fescue, the SFA/PUFA ratio decreased to $11.5^{\circ} \mathrm{C}$ and subsequently increased as temperature increased; this relationship was significant. Perennial ryegrass showed a significant linear slope in SFA/PUFA ratio of -0.005 as temperature increased. Alfalfa had the highest SFA/PUFA ratio between 0.3-0.4, while Kentucky bluegrass, perennial ryegrass, and tall fescue all ranged between 0.2-0.3. Temperature was a strong predictor of the SFA/PUFA ratio in Kentucky bluegrass $\left(R^{2}=0.66\right)$, was a moderate predictor in alfalfa $\left(R^{2}=0.37\right)$ and was a weak predictor in the remaining species $\left(\mathrm{R}^{2}<0.30\right)$. The ratio of SFA/PUFA in Kentucky bluegrass, white clover, alfalfa, and smooth bromegrass was best described using a cubic function, in tall fescue was best described using a quadratic function, and in orchardgrass and perennial ryegrass was best described using a linear function. 
Table 3.3: Linear, quadratic, and cubic regression analyses for the relationship between temperature and SFA, MUFA, and PUFA of seven plant species. The $\mathrm{R}^{2}$ value refers to the fit of the overall regression model, $\beta_{1}$ to the linear regression coefficient, $\beta_{2}$ to the quadratic regression coefficient, and $\beta_{3}$ to the cubic regression coefficient $\mathrm{ns}=\mathrm{P}>0.05 ; *=\mathrm{P}<0.05 ; * *=\mathrm{P}<0.01 ; * * *=\mathrm{P}<0.001$.

\begin{tabular}{|c|c|c|c|c|c|c|c|c|c|c|c|c|c|c|c|}
\hline \multirow[t]{2}{*}{ Species } & \multicolumn{3}{|c|}{ SFA } & \multirow[t]{2}{*}{$\mathbf{R}^{2}$} & \multirow[t]{2}{*}{ df } & \multicolumn{3}{|c|}{ MUFA } & \multirow[t]{2}{*}{$\mathbf{R}^{2}$} & \multirow[t]{2}{*}{ df } & \multicolumn{3}{|c|}{ PUFA } & \multirow[t]{2}{*}{$\mathbf{R}^{2}$} & \multirow[t]{2}{*}{ df } \\
\hline & $\beta_{1}$ & $\boldsymbol{\beta}_{2}$ & $\boldsymbol{\beta}_{3}$ & & & $\beta_{1}$ & $\boldsymbol{\beta}_{2}$ & $\boldsymbol{\beta}_{3}$ & & & $\beta_{1}$ & $\boldsymbol{\beta}_{2}$ & $\boldsymbol{\beta}_{3}$ & & \\
\hline Kentucky bluegrass & $-4.71 * * *$ & $4.59 * * *$ & $-4.49 * * *$ & 0.58 & 3 & $2.10^{*}$ & $-2.22 *$ & --- & 0.11 & 2 & $3.39 * *$ & $-3.37 * *$ & $3.36 * *$ & 0.50 & 3 \\
\hline Orchardgrass & $-1.67^{\mathrm{ns}}$ & --- & --- & 0.41 & 1 & $-5.32 * * *$ & --- & --- & 0.27 & 1 & $2.40 *$ & --- & --- & 0.35 & 1 \\
\hline Perennial ryegrass & $-1.82^{\mathrm{ns}}$ & $1.86^{\mathrm{ns}}$ & $-1.92^{\mathrm{ns}}$ & 0.15 & 3 & $2.75 * *$ & $-3.02 * *$ & --- & 0.07 & 2 & $1.10^{\mathrm{ns}}$ & $-1.21^{\mathrm{ns}}$ & $1.33^{\mathrm{ns}}$ & 0.08 & 3 \\
\hline White clover & $-2.00^{\mathrm{ns}}$ & --- & --- & 0.11 & 1 & $-4.00 * *$ & --- & --- & 0.41 & 1 & $3.42 * *$ & --- & --- & 0.64 & 1 \\
\hline Tall fescue & $-3.36 * *$ & $3.25 * *$ & $-3.15 * *$ & 0.35 & 3 & $-0.69^{\mathrm{ns}}$ & $0.70^{\mathrm{ns}}$ & $-0.70^{\mathrm{ns}}$ & 0.27 & 3 & $2.44 *$ & $-2.37 *$ & $2.30 *$ & 0.37 & 3 \\
\hline Alfalfa & $-2.19 *$ & $2.23 *$ & $-2.27 *$ & 0.02 & 3 & $-4.32^{\mathrm{ns}}$ & --- & --- & 0.10 & 1 & $2.21 *$ & $-2.22 *$ & $2.25^{*}$ & 0.16 & 3 \\
\hline Smooth bromegrass & $-1.91^{\mathrm{ns}}$ & $2.00^{\mathrm{ns}}$ & --- & 0.16 & 2 & $-2.36^{*}$ & $2.48^{*}$ & --- & 0.12 & 2 & $2.42 *$ & $-2.55^{*}$ & --- & 0.07 & 2 \\
\hline
\end{tabular}


Table 3.4: Linear, quadratic, and cubic regression analyses for the relationship between temperature and SFA/PUFA of seven plant species. The $\mathrm{R}^{2}$ value refers to the fit of the overall regression model, $\beta_{1}$ to the linear regression coefficient, $\beta_{2}$ to the quadratic regression coefficient, and $\beta_{3}$ to the cubic regression coefficient: $\mathrm{ns}=\mathrm{P}>0.05 ; *=\mathrm{P}<0.05 ; * *=\mathrm{P}<0.01 ; * * *=\mathrm{P}<0.001$.

\begin{tabular}{cccccc}
\hline \hline Species & \multicolumn{3}{c}{ SFA/PUFA } & \multirow{2}{*}{$\mathbf{R}^{\mathbf{2}}$} & df \\
\cline { 2 - 4 } & $\boldsymbol{\beta}_{\mathbf{1}}$ & $\boldsymbol{\beta}_{\mathbf{2}}$ & $\boldsymbol{\beta}_{\mathbf{3}}$ & & \\
\hline Kentucky bluegrass & $-4.70^{* * *}$ & $4.60^{* * *}$ & $-4.51^{* * *}$ & 0.66 & 3 \\
Orchardgrass & $-1.82^{\mathrm{ns}}$ & --- & --- & 0.17 & 1 \\
Perennial ryegrass & $-3.12^{* *}$ & --- & --- & 0.21 & 1 \\
White clover & $-1.35^{\mathrm{ns}}$ & $1.32^{\mathrm{ns}}$ & $-1.30^{\mathrm{ns}}$ & 0.22 & 3 \\
Tall fescue & $-2.13^{*}$ & $2.22^{*}$ & --- & 0.24 & 2 \\
Alfalfa & $-2.28^{*}$ & $2.31^{*}$ & $-2.34^{*}$ & 0.37 & 3 \\
& & & & & \\
Smooth bromegrass & $-1.32^{\mathrm{ns}}$ & $1.20^{\mathrm{ns}}$ & $-1.09^{\mathrm{ns}}$ & 0.25 & 3 \\
\hline
\end{tabular}



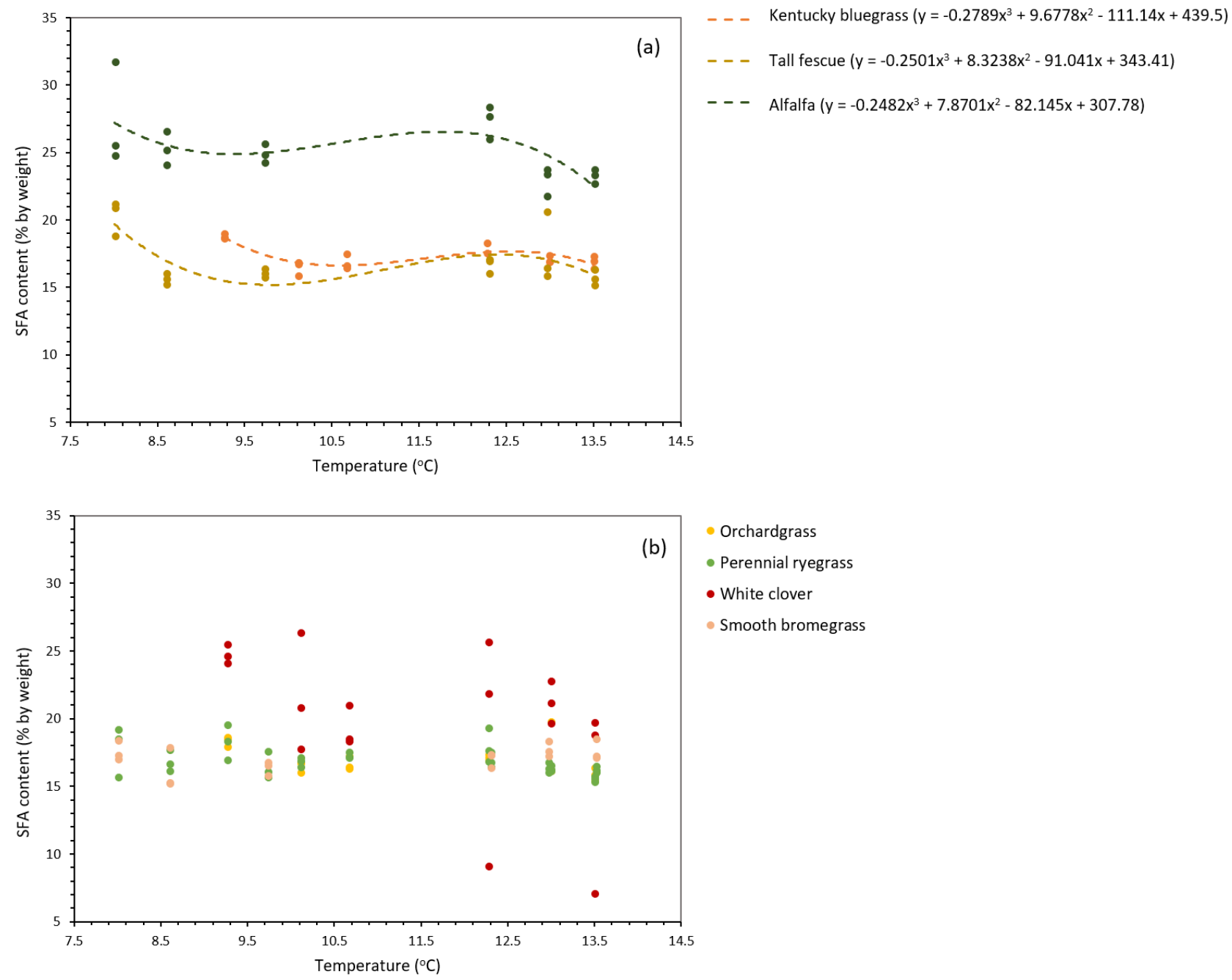

Fig. 3.2: Percent by dry weight content of (a) significant SFA trends and (b) non-significant SFA data as a function of temperature ( $\mathrm{N}=18$ per species). Dashed lines represent significant linear, quadratic, and cubic trends, as indicated by regression equations (shown on the right). 

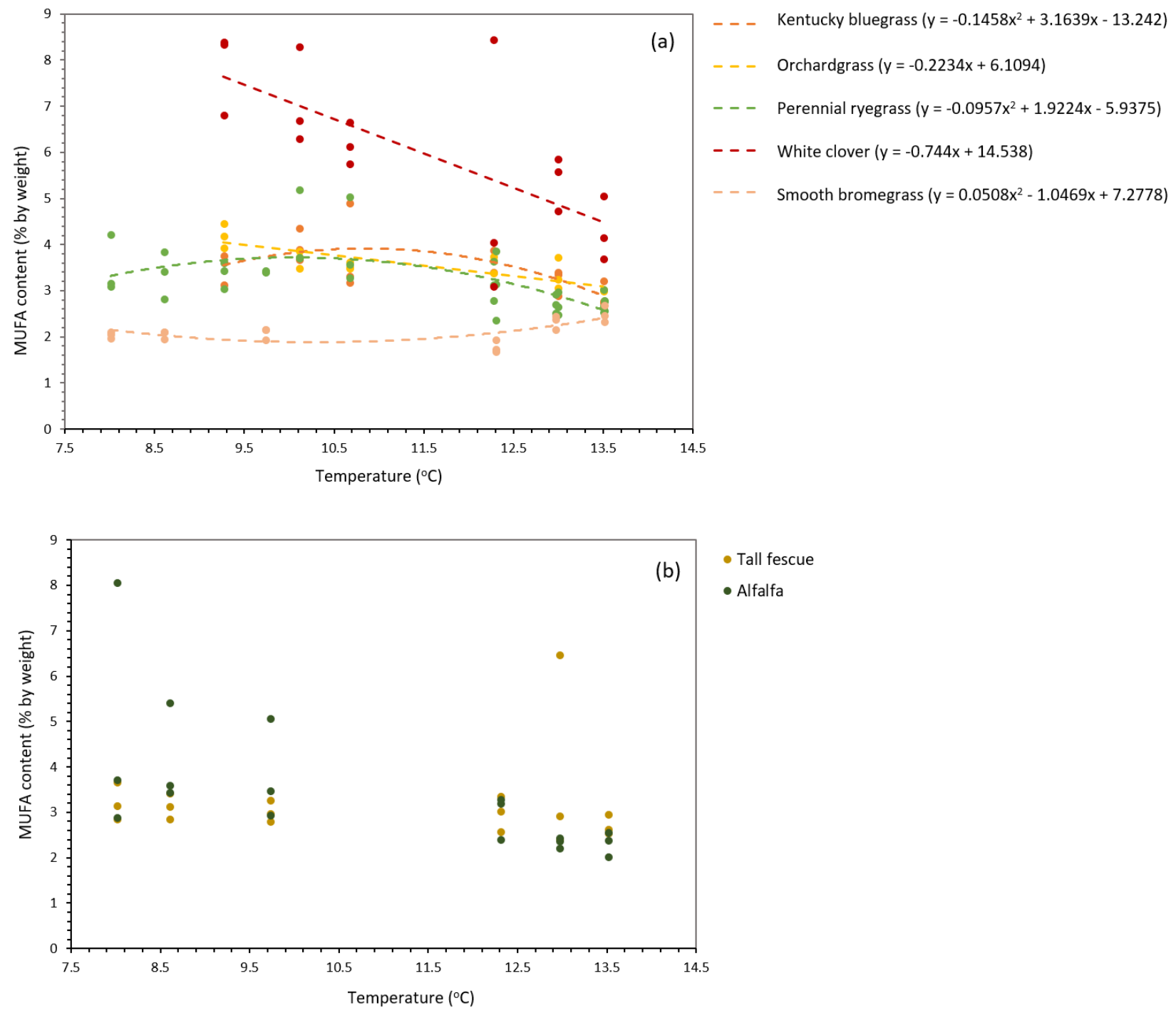

Fig. 3.3: Percent by dry weight content of (a) significant MUFA trends and (b) non-significant MUFA data as a function of temperature ( $\mathrm{N}=18$ per species). Dashed lines represent significant linear, quadratic, and cubic trends, as indicated by regression equations (shown on the right). 

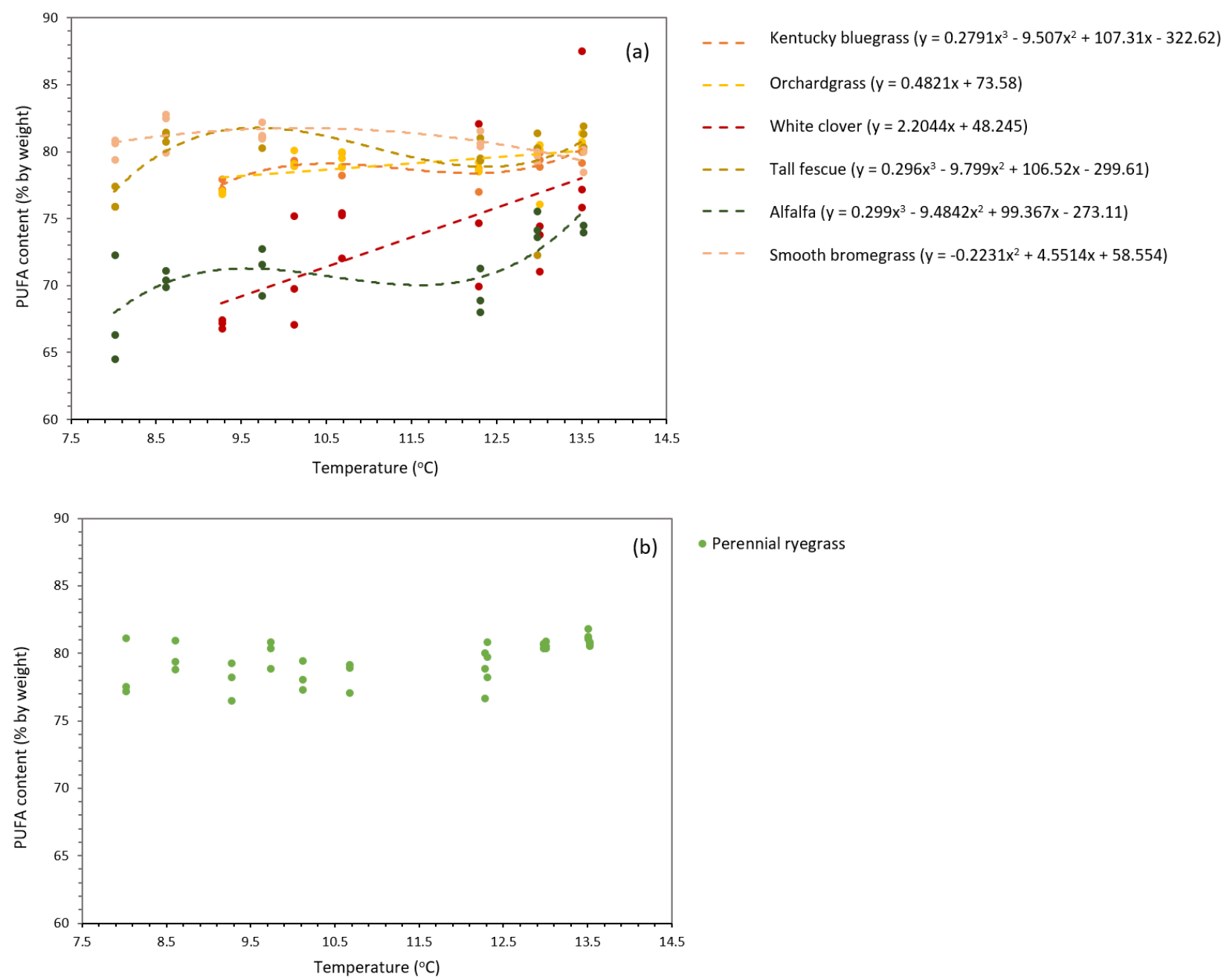

Fig. 3.4: Percent by dry weight content of (a) significant PUFA trends and (b) non-significant PUFA data as a function of temperature $(\mathrm{N}=18$ per species). Dashed lines represent significant linear, quadratic, and cubic trends, as indicated by regression equations (shown on the right). 

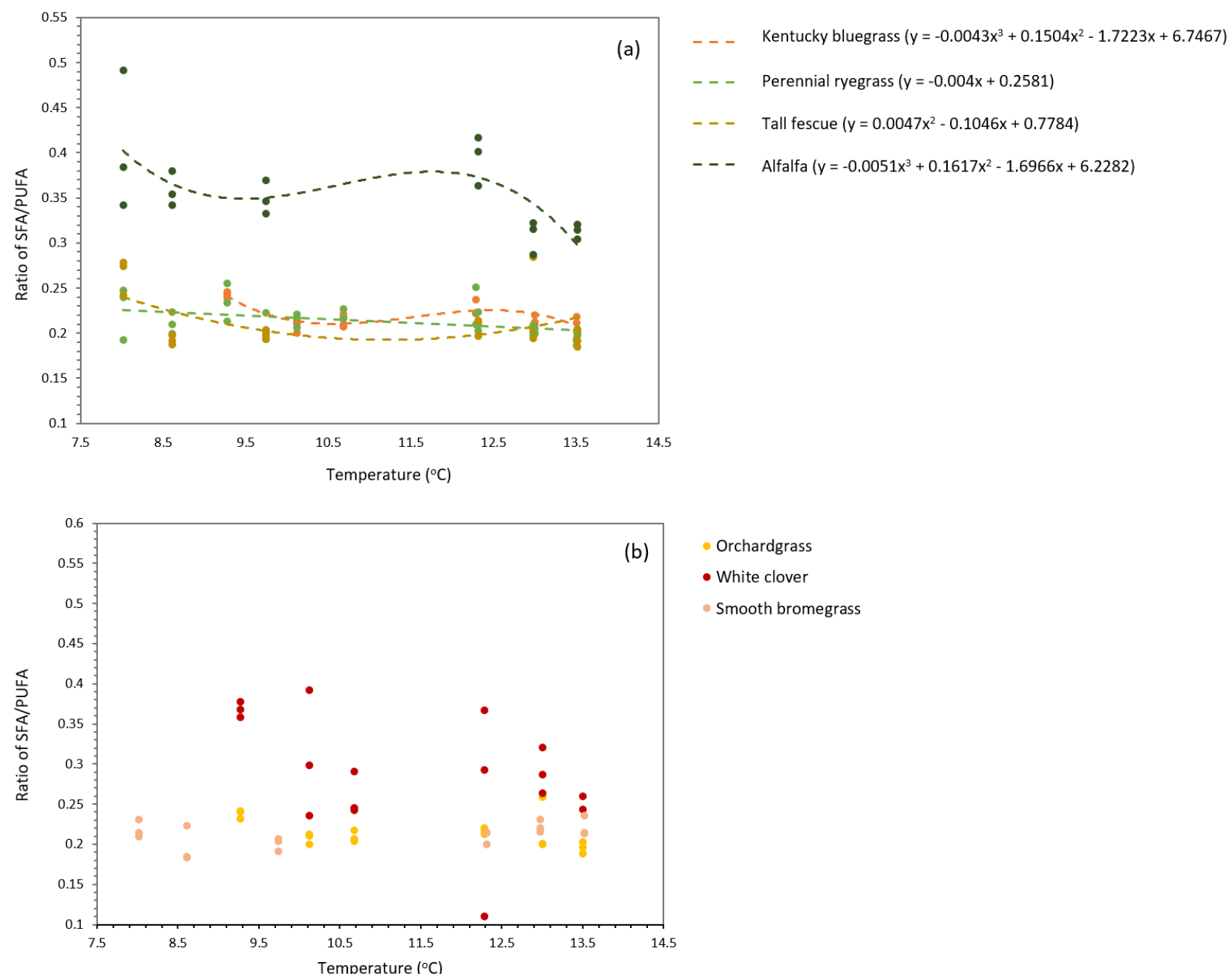

- Orchardgrass

- White clover

- Smooth bromegrass

Fig. 3.5: The ratio of SFA/PUFA of seven plant species as a function of temperature ( $\mathrm{N}=18$ per species) with (a) significant trends and (b) non-significant data. Dashed lines represent significant linear, quadratic, and cubic trends, as indicated by regression equations (shown on the right).

\subsection{Does increasing temperature affect the relative amount of major plant fatty acids?}

Temperature was typically a strong predictor of FA content across all prominent (i.e., > 1.0 $\mathrm{mg} / \mu \mathrm{g}$ dry weight $) \mathrm{FA}$ in Kentucky bluegrass $\left(\mathrm{R}^{2}>0.5\right)$, whereas it was a moderate predictor across all prominent FA in tall fescue and orchardgrass $\left(\mathrm{R}^{2}=0.3-0.5\right)$; this was also true for white clover, with the exception of temperature being a strong predictor of 16:0 content in this species. Perennial ryegrass and smooth bromegrass showed temperature as a weak predictor across all FA $\left(\mathrm{R}^{2}<0.3\right)$; the same trend was true for alfalfa with the exception of 18:1n-9c, where temperature was a strong predictor of FA content. 
In Kentucky bluegrass, the 15:0 and 16:0 content was best described using a quadratic function, the 18:0 and 18:1n-9c content was best described using a linear function, and the ALA and LNA content was best described using a cubic function (Table 3.5). In orchardgrass, quadratic and cubic regressions were used for 16:0, 18:0 and 18:1n-9c, and 15:0, ALA and LNA, respectively. The SFA (15:0, 16:0, 18:0) in perennial ryegrass were best described using a linear function, while the unsaturated FA $(18: 1 \mathrm{n}-9 \mathrm{c}$, ALA, LNA) were best described using a quadratic function. Most FA in white clover showed linear patterns (15:0, 18:0, 18:1n-9c, LNA), while 16:0 and ALA showed cubic patterns. In tall fescue, 15:0, 16:0, and 18:1n-9c content was best described using a cubic function whereas 18:0, ALA, and LNA content was best described using a linear function. Three FA in alfalfa were quadratic (15:0, 16:0, ALA) and three were linear (18:0, 18:1n-9c, LNA). Finally - with the exception of 15:0 and 18:1n-9c, which were linear - all FA in smooth bromegrass showed quadratic patterns (16:0, 18:0, ALA, LNA).

There were three major SFA observed in these plant species: 15:0, 16:0, and 18:0. In orchardgrass, $15: 0$ content decreased to a minimum at $\sim 10.5^{\circ} \mathrm{C}$ and increased to a maximum at $12.5^{\circ} \mathrm{C}$ as temperature increased; this relationship was significant (Fig. 3.6). Smooth bromegrass showed a significant positive linear slope in 15:0 content of 0.12 as temperature increased. Both species had 15:0 content between $1.5-2.5 \%$. Conversely, with the exception of smooth bromegrass, most species (tall fescue, white clover, alfalfa, perennial ryegrass) showed a significant negative relationship between temperature and 16:0 content (Fig. 3.7). Alfalfa had the highest 16:0 content (between 16.0-18.0\%) while tall fescue, white clover, perennial ryegrass, and smooth bromegrass all ranged between 11.0-15.0\%. The final saturated FA - 18:0 - significantly declined in perennial ryegrass, tall fescue, and alfalfa, whereas smooth bromegrass increased in 18:0 content as temperature increased (Fig. 3.8). Perennial ryegrass, tall fescue, and smooth bromegrass had similar relative 18:0 content (between 1.0-2.0\%) while alfalfa showed higher levels of this FA (between 2.5-4.5\%).

The FA 18:1n-9c was the only major plant MUFA observed in these trials. Kentucky bluegrass, orchardgrass, and white clover showed significant negative linear slopes in 18:1n-9c content between 0.08 and -0.58 , and alfalfa showed a significant positive linear slope of 0.19 as temperature increased (Fig. 3.9). Each of these species showed 18:1n-9c content between 1.0-3.0\%, with the exception of white clover, which had higher 18:1n-9c content (between 3.0-6.0\%).

Alpha-linolenic acid (ALA) and LNA (LNA) were the major PUFA observed in these plant species. Most species (i.e., Kentucky bluegrass, orchardgrass, white clover, tall fescue) increased in ALA content with increasing temperature and ranged between 40.0 and $70.0 \%$ relative content. Conversely, 
most species (i.e., Kentucky bluegrass, orchardgrass, tall fescue, alfalfa) - with the exception of white clover - decreased overall in LNA content as temperature increased. Each of these species had a range of 10.0-30.0\% relative content of LNA. Alpha-linolenic acid (ALA) was the most prominent FA in all species in these trials. 
Table 3.5: Linear, quadratic, and cubic regression analyses for the relationship between temperature and 15:0, 16:0, 18:0, 18:1n-9c, ALA, and LNA of seven plant species. The $R^{2}$ value refers to the fit of the overall regression model, $\beta 1$ to the linear regression coefficient, $\beta 2$ to the quadratic regression coefficient, and $\beta 3$ to the cubic regression coefficient: $\mathrm{ns}=\mathrm{P}>0.05 ; *=\mathrm{P}<0.05 ; * *=\mathrm{P}<0.01 ; * * *=\mathrm{P}<0.001$.

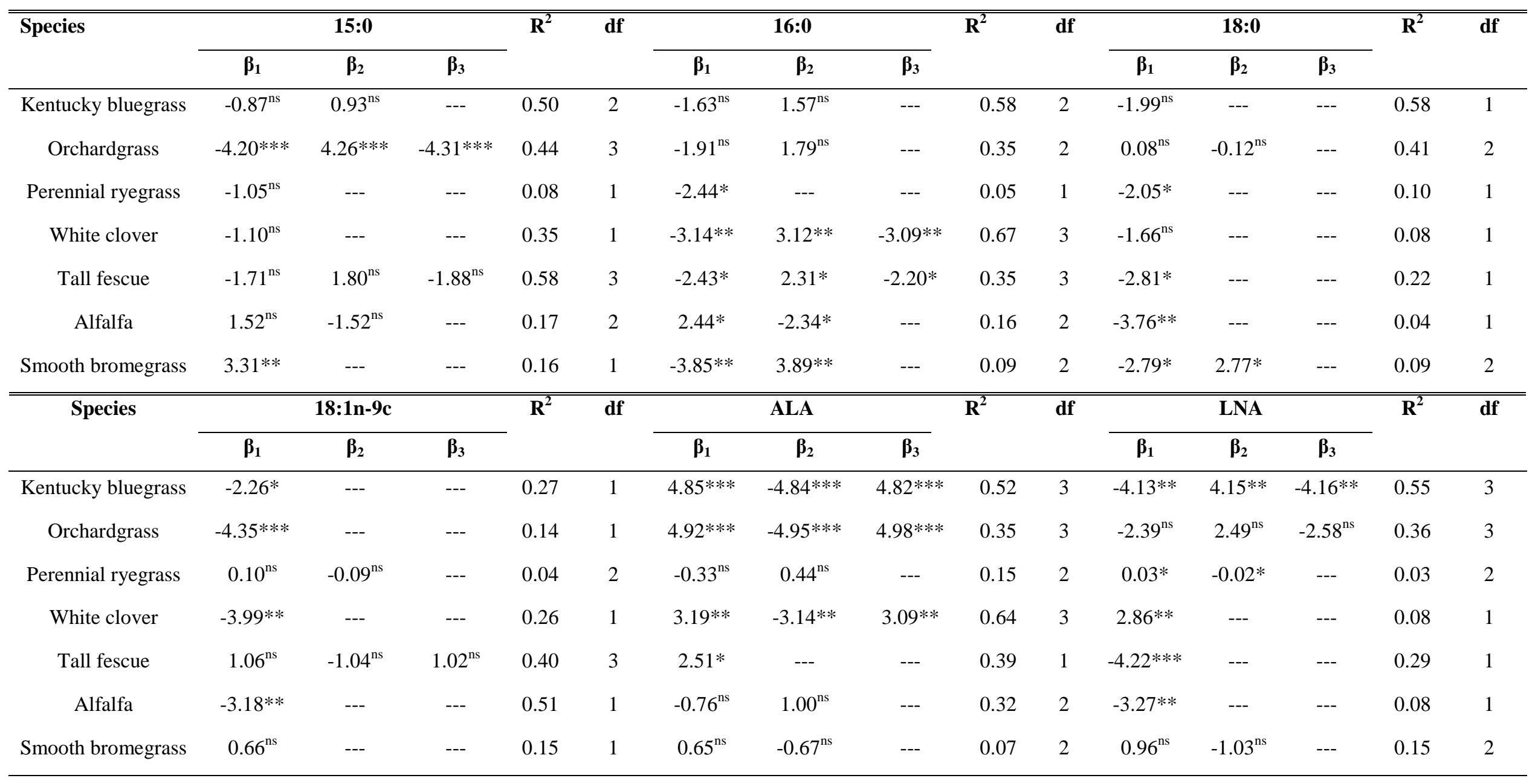



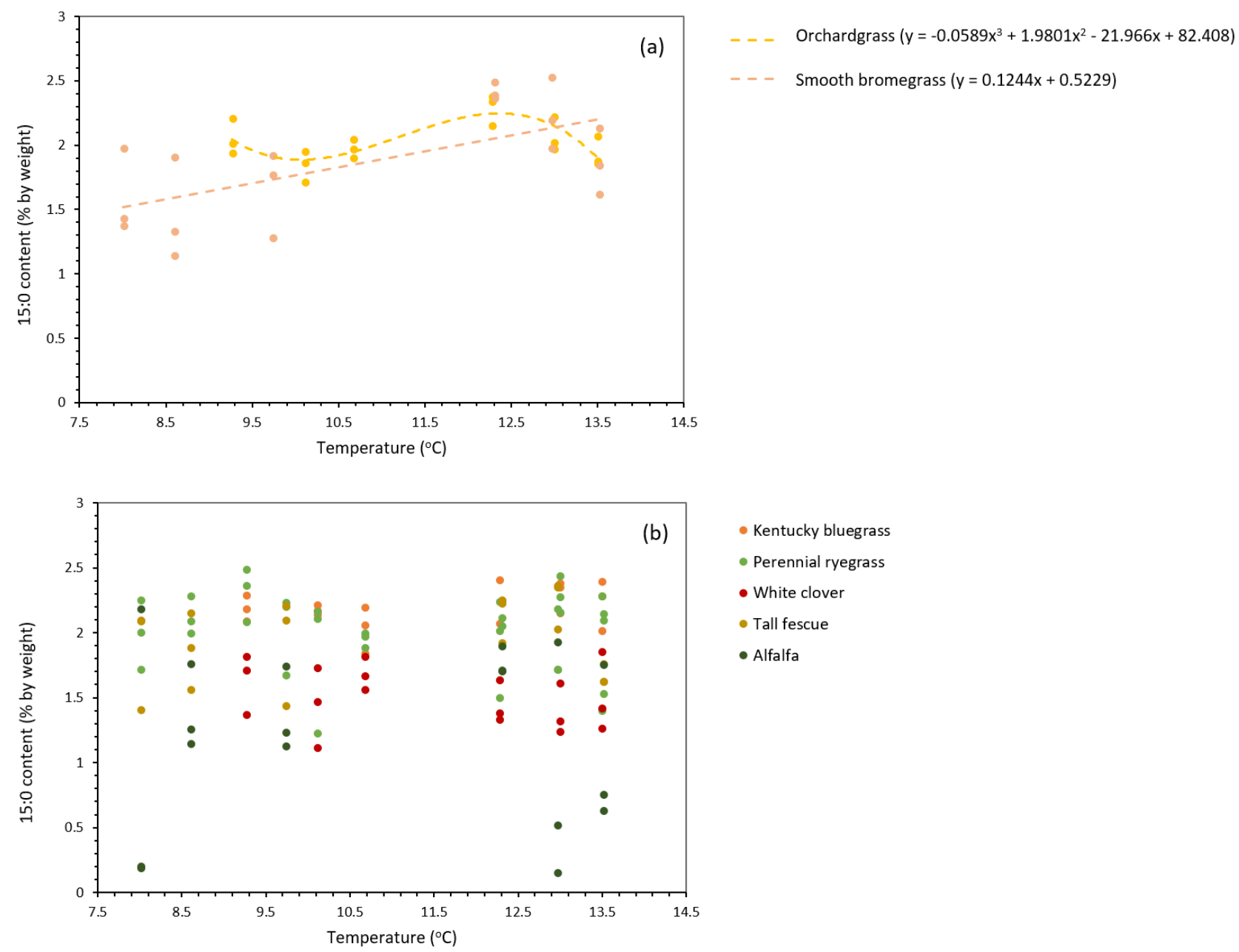

Fig. 3.6: Percent content of (a) significant 15:0 trends and (b) non-significant 15:0 data as a function of temperature ( $\mathrm{N}=18$ per species). Dashed lines represent significant linear, quadratic, and cubic trends, as indicated by regression equations (shown on the right). 

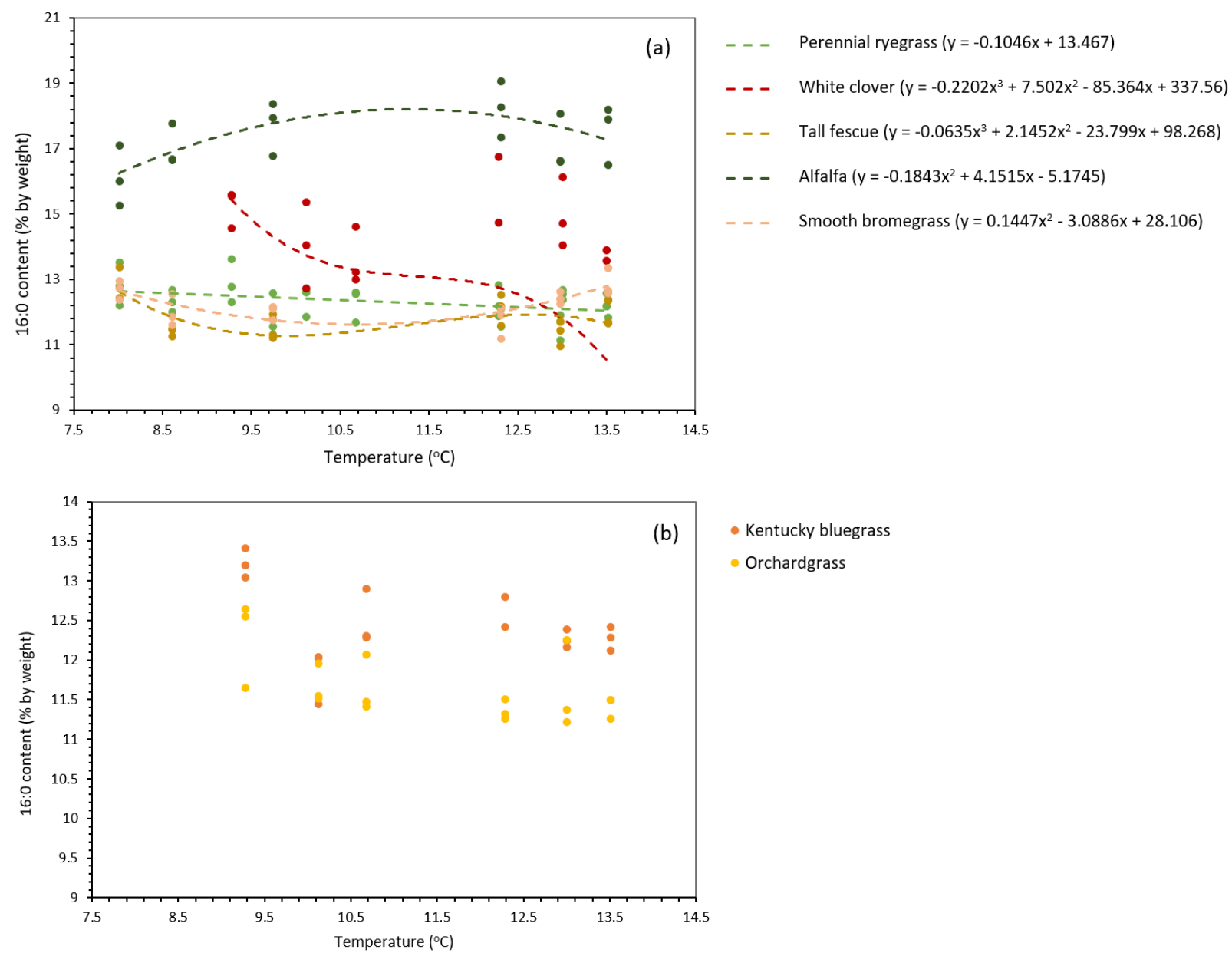

Fig. 3.7: Percent content of (a) significant 16:0 trends and (b) non-significant 16:0 data as a function of temperature ( $\mathrm{N}=18$ per species). Dashed lines represent significant linear, quadratic, and cubic trends, as indicated by regression equations (shown on the right). 

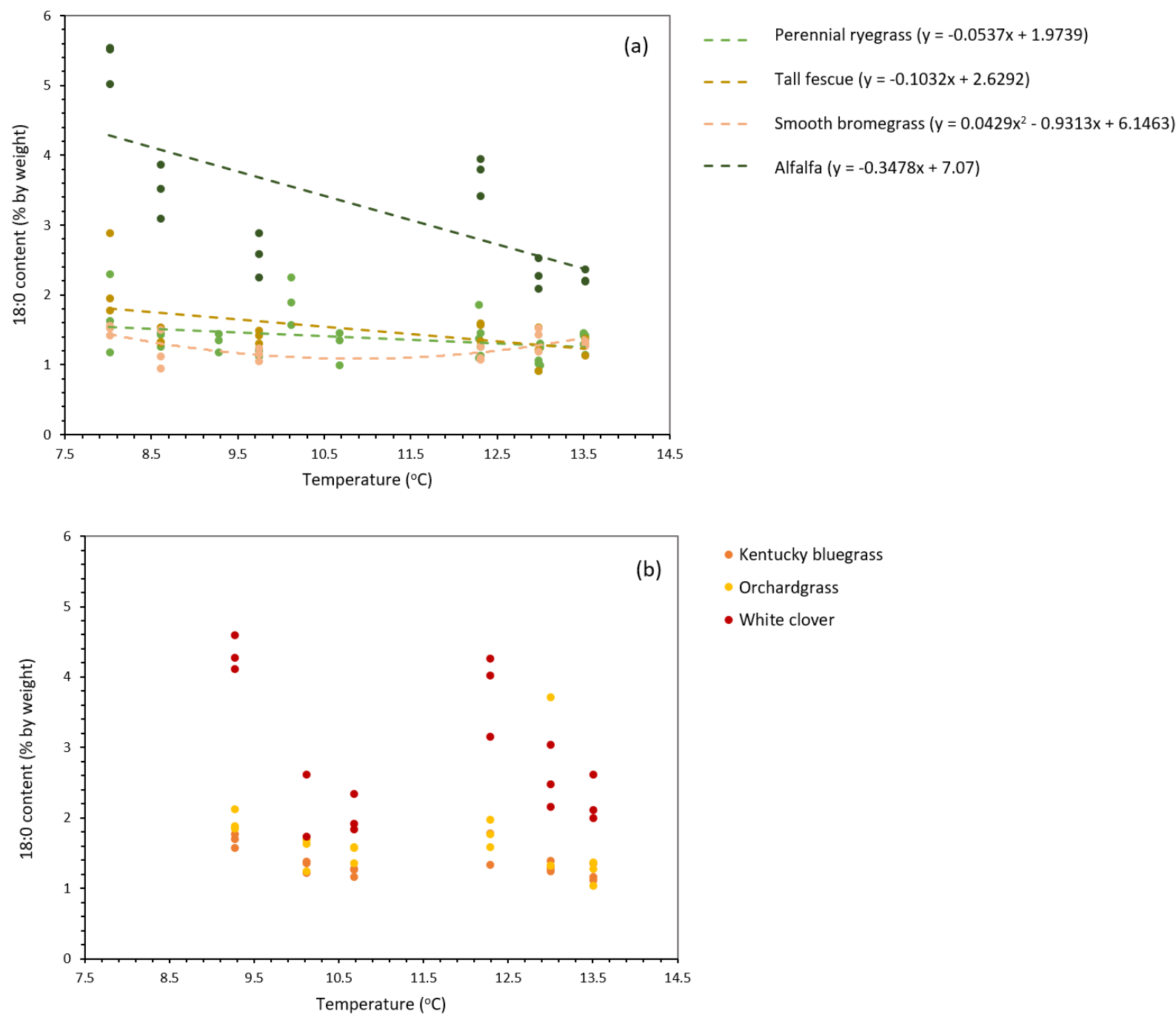

Fig. 3.8: Percent content of (a) significant 18:0 trends and (b) non-significant 18:0 data as a function of temperature ( $\mathrm{N}=18$ per species). Dashed lines represent significant linear, quadratic, and cubic trends, as indicated by regression equations (shown on the right). 

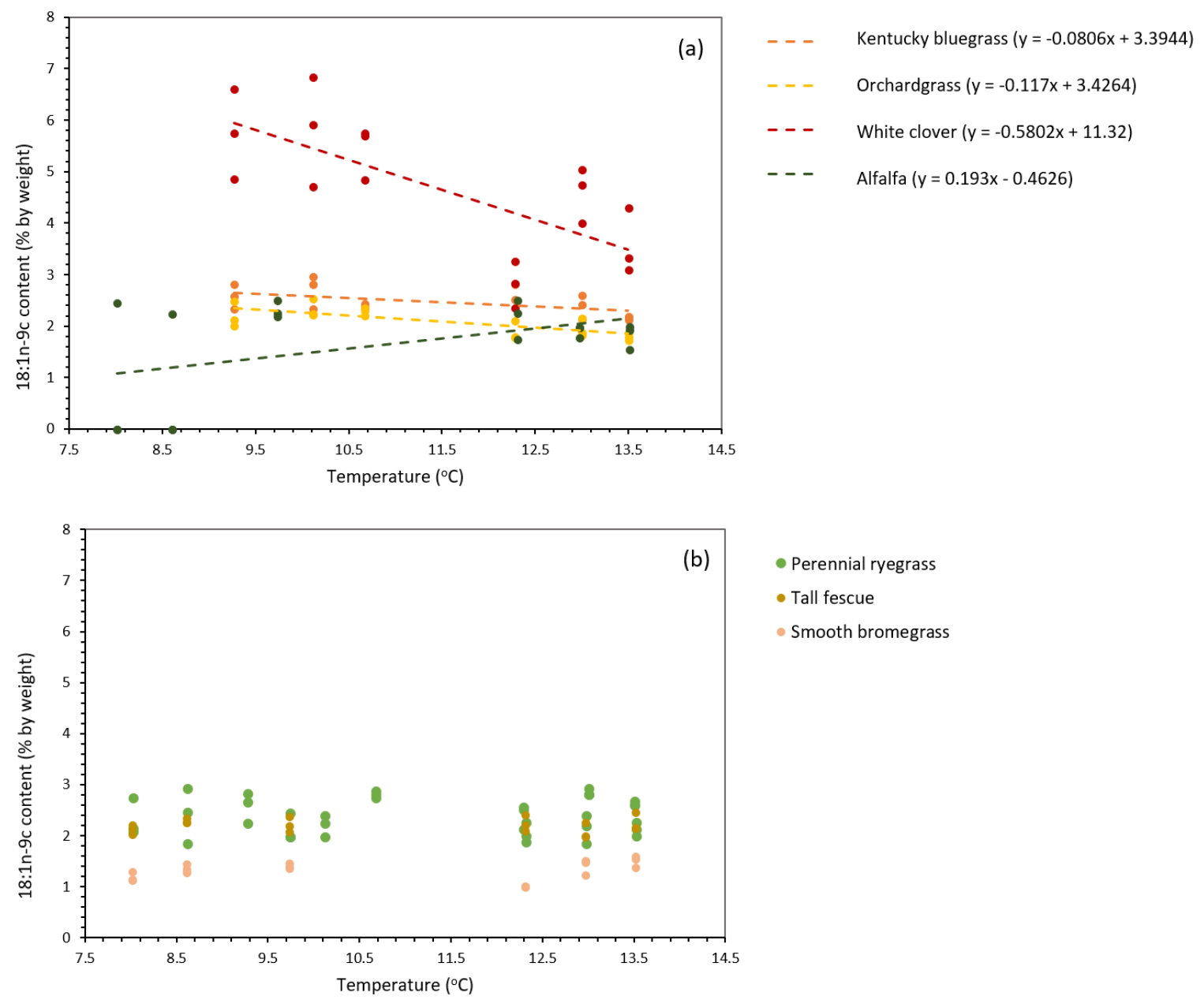

Fig. 3.9: Percent content of (a) significant 18:1n-9c trends and (b) non-significant 18:1n-9c data as a function of temperature ( $\mathrm{N}=18$ per species). Dashed lines represent significant linear, quadratic, and cubic trends, as indicated by regression equations (shown on the right). 

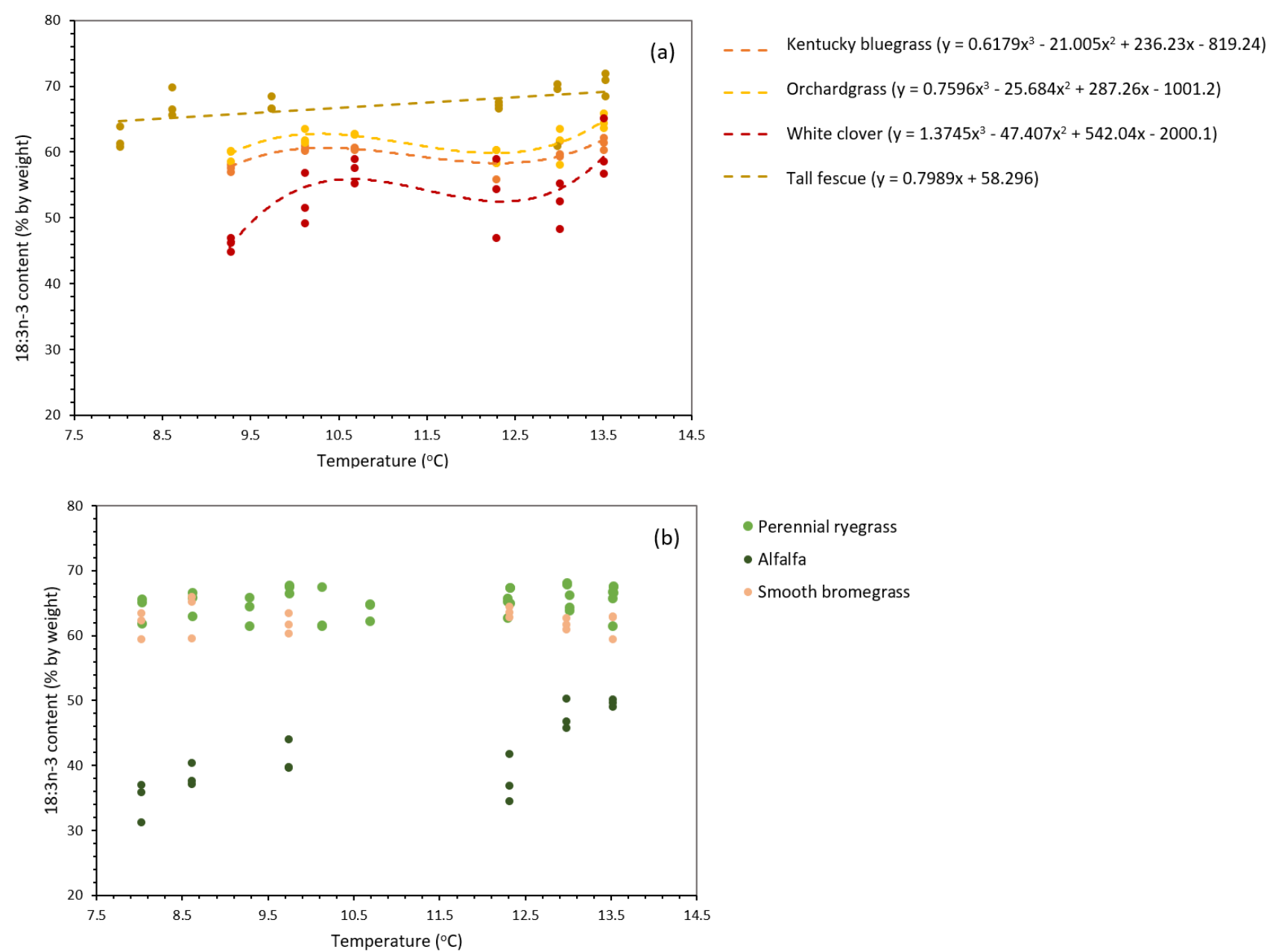

- Perennial ryegrass

- Alfalfa

- Smooth bromegrass

Fig. 3.10: Percent content of (a) significant ALA (ALA) trends and (b) non-significant ALA data as a function of temperature ( $\mathrm{N}=18$ per species). Dashed lines represent significant linear, quadratic, and cubic trends, as indicated by regression equations (shown on the right). 

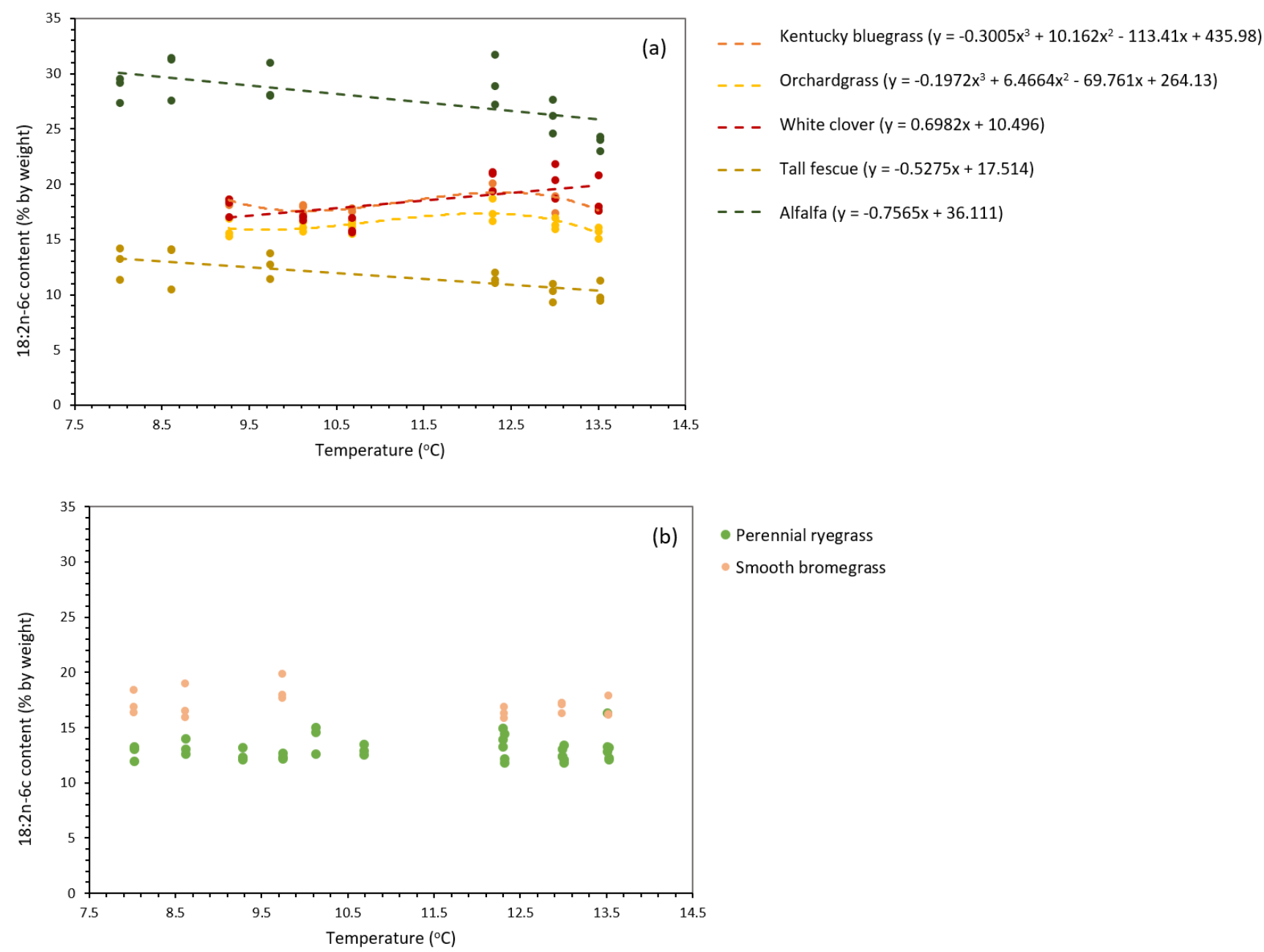

Fig. 3.11: Percent content of (a) significant LNA (LNA) trends and (b) non-significant LNA data as a function of temperature ( $\mathrm{N}=18$ per species). Dashed lines represent significant linear, quadratic, and cubic trends, as indicated by regression equations (shown on the right).

\subsection{Does increasing temperature have an effect on the overall Unsaturation Index in plants?}

In Kentucky bluegrass, UI increased to a maximum at $\sim 10.5^{\circ} \mathrm{C}$ and decreased to a minimum at $12.5^{\circ} \mathrm{C}$ as temperature increased, whereas UI in alfalfa increased to a maximum at $9.5^{\circ} \mathrm{C}$ and decreased to a minimum at $12.0^{\circ} \mathrm{C}$; these relationships were significant (Table 3.6, Fig. 3.12). White clover showed a significant positive linear slope in UI of 5.0 as temperature increased. Kentucky bluegrass had the highest UI (between 216-224), followed by white clover (between 196-212), followed by alfalfa (between 180196). Trends in other species were non-significant. Temperature was a strong predictor of UI in Kentucky bluegrass and white clover $\left(\mathrm{R}^{2}>0.5\right)$ and was a weak predictor in alfalfa $\left(\mathrm{R}^{2}<0.3\right)$. Unsaturation index in 
Kentucky bluegrass, perennial ryegrass, and alfalfa was best described using a cubic function, in tall fescue and smooth bromegrass was best described using a quadratic function and in orchardgrass and white clover was best described using a linear function.

Table 3.6: Linear, quadratic, and cubic regression analyses for the relationship between temperature and $\mathrm{UI}$ of seven plant species. The $\mathrm{R}^{2}$ value refers to the fit of the overall regression model, $\beta_{1}$ to the linear regression coefficient, $\beta_{2}$ to the quadratic regression coefficient, and $\beta_{3}$ to the cubic regression coefficient: $\mathrm{ns}=\mathrm{P}>0.05 ; *=\mathrm{P}<0.05 ; * *=\mathrm{P}<0.01 ; * * *=\mathrm{P}<0.001$.

\begin{tabular}{|c|c|c|c|c|c|}
\hline \multirow[t]{2}{*}{ Species } & \multicolumn{3}{|c|}{$\overline{\text { UI }}$} & \multirow[t]{2}{*}{$\mathbf{R}^{2}$} & \multirow[t]{2}{*}{ df } \\
\hline & $\beta_{1}$ & $\boldsymbol{\beta}_{2}$ & $\boldsymbol{\beta}_{3}$ & & \\
\hline Kentucky bluegrass & $4.67 * * *$ & $-4.63 * * *$ & $4.60 * * *$ & 0.50 & 3 \\
\hline Orchardgrass & $-1.78^{\mathrm{ns}}$ & --- & --- & 0.46 & 1 \\
\hline Perennial ryegrass & $1.34^{\mathrm{ns}}$ & $-1.46^{\mathrm{ns}}$ & $1.57^{\mathrm{ns}}$ & 0.43 & 3 \\
\hline White clover & $2.45^{*}$ & -- & -- & 0.73 & 1 \\
\hline Tall fescue & $1.25^{\mathrm{ns}}$ & $-1.18^{\mathrm{ns}}$ & --- & 0.34 & 2 \\
\hline Alfalfa & $2.29 *$ & $-2.34 *$ & $2.40^{*}$ & 0.17 & 3 \\
\hline Smooth bromegrass & $1.42^{\mathrm{ns}}$ & $-1.51^{\mathrm{ns}}$ & --- & 0.10 & 2 \\
\hline
\end{tabular}



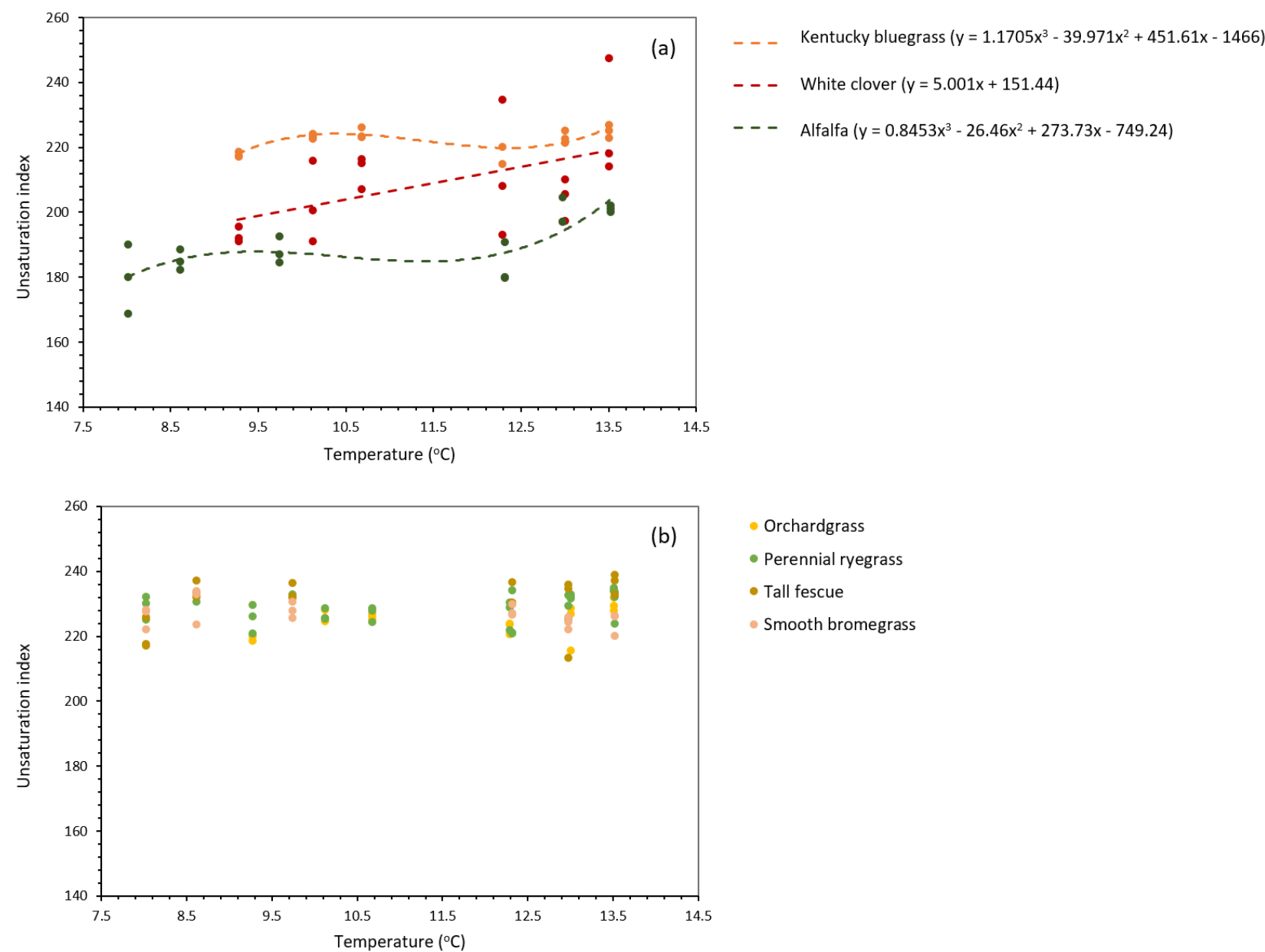

Fig. 3.12: Unsaturation index, based on percent by dry weight FA content of (a) significant trends and (b) non-significant data as a function of temperature ( $\mathrm{N}=18$ per species). Dashed lines represent significant linear, quadratic, and cubic trends, as indicated by regression equations (shown on the right). 


\section{Discussion}

The forage plants grown in this experiment showed strong responses to the applied climate warming. Each study species had a unique response to the applied temperature treatment, but there were some common patterns in terms of FA content: SFA and MUFA tended to decrease with increasing temperature and PUFA tended to increase with increasing temperature. All species were rich in PUFA ( 75\%), and were particularly rich in ALA and LNA, which together accounted for $\sim 80 \%$ of the total measured FAME. These qualities are unique, as other pasture plants (i.e., corn, wheat, soy) have been observed to have $~ 50 \%$ PUFA content and $\sim 10 \%$ and $40 \%$ ALA and LNA content (\% FAME), respectively (Orhan et al. 2009, Silva et al. 2014, Marchand et al. 2016, Morris et al. 2018, unpublished). Additionally, plants developed faster and grew heavier as temperature was increased; this affected the trends of the absolute FA values and so only percent by dry weight values were considered. These changes, resulting from increased ambient temperature, affect the nutrition and appearance of plants at the base of the agricultural food web, since the pasture plants observed here changed in size and FA content and composition. The species observed in this study are consumed by both domestic and wild herbivores; therefore, any nutritional changes resulting from increased temperature may affect agricultural ecosystem dynamics. Some results in these trials contrasted with predictions based solely on the mechanisms of homeoviscous adaptation, but other factors may have been at play and are discussed below. My results suggest that an increase in SAT due to climate warming in Southern Ontario may improve nutrition in pasture plants (e.g., decreased SFA and increased healthy PUFA and EFA), which may thus confer nutritional improvements in primary consumers - both domestic and wild - and in secondary consumers.

\section{$\underline{4.1 \text { Effects of temperature on fatty acid content and profile }}$}

Consistent with the literature, I observed 16:0 to be the most prominent SFA ( $72.0 \%$ of all SFA content) in the Poaceae and Fabaceae plant species (Dolde et al. 1999, Gul et al. 2008, Liu et al. 2014). Therefore, 16:0 was the main driver for changes in SFA content as a result of increasing temperatures. As a common precursor for early-stage lipid synthesis, 16:0 is one of the most common SFA observed in plants (Ohlrogge and Browse 1995, Thelen and Ohlrogge 2002). Based on principles of homeoviscous adaptation, the SFA content in the experimental plants should have increased with increasing temperature (Sinensky 1974, Behrouzian and Buist 2002, Nozawa 2011, Ernst et al. 2016, Saunders et al. 2016) to respond to presumed increases in membrane fluidity (Feller et al. 2001, Arts and Kohler 2008). Contrary to the literature (i.e., studies on tobacco and sunflower species), four species (Kentucky bluegrass, perennial ryegrass, tall fescue, alfalfa) showed significant decreases in 16:0 content and SFA content, 
beyond atmospheric temperatures of $\sim 11.5^{\circ} \mathrm{C}$ (Murakami et al. 2000, Flagella et al. 2002). I also observed significant decreases in MUFA content as temperature increased in three species (Kentucky bluegrass, orchardgrass, white clover), which is consistent with other findings in tobacco and daisy, where similar temperature increases and FA responses were measured (Murakami et al. 2000, Krol and Paszko 2016). I expected PUFA content - and thus UI - to decrease with increasing temperature as per other observed instances of homeoviscous adaptation in response to temperature increases in sunflower, rape, and Arabidopsis (Tremolieres et al 1982, Upchurch 2008). However, four experimental species (Kentucky bluegrass, orchardgrass, white clover, tall fescue) increased in PUFA content at temperatures above $11.5^{\circ} \mathrm{C}$, contrary to previous observations in sunflower, rape, and Arabidopsis (Tremolieres et al 1982, Falcone et al. 2004). Two of these species - Kentucky bluegrass and white clover - had increased UI with increasing temperature, whereas Falcone et al. (2004) observed decreased overall unsaturation with increased temperature in Arabidopsis. Therefore, most of my results were contrary to what would be expected based on experiments testing hypotheses of the influence of temperature on homeoviscous adaptation.

The observed species are all considered cool-season plant species (Bunger et al. 2012) which means the temperature for optimal growth ranges from 10.0 to $30.0^{\circ} \mathrm{C}$ (Berry and Bjorkman 1980 , Jiang and Huang 2001, Liu and Huang 2003). Other cool-season species - such as Saussurea medusa (sawwort) and Solms-Laubachia linearifolia (variety of turnip) - have shown similar patterns in FA content as the current study species when exposed to increased temperature (i.e., 20.0 versus $32.0^{\circ} \mathrm{C}$ ). These patterns are, namely, decreased SFA content and increased PUFA content and unsaturation levels (Liu and Huang 2004, Zheng et al. 2011). The patterns in FA profile as a function of temperature are likely related to the high level of phenotypic plasticity required to survive in a temperate ecosystem where environmental temperature is often fluctuating (Franks et al. 2013, Merila and Hendry 2013). Phenotypic plasticity is defined as the ability of a single genotype to produce a variety of phenotypes under different environmental conditions (Bradshaw 1965, Sultan 1995). This phenomenon has been observed in terrestrial plants (Richards et al. 2006), specifically with regard to FA content and composition (Broun et al. 1998, Sun et al. 2016). Sun et al. (2016) exposed maize plants (of the same genotype) to different temperature treatments and observed differences in the FA content and composition between temperature treatments. Namely, they saw a decreased in overall FA content, as well as PUFA content within a genotype as temperature was increased (Sun et al. 2016). This may be caused by changes in FA enzyme regulation, which has been observed to occur in single genotypes of Arabidopsis under different environmental conditions (Broun et al. 1998, Borges 2009). The day-to-day environmental conditions experienced by temperate terrestrial plants, especially during the spring/summer months in North 
America, are wide-ranging especially with respect to temperature. Therefore terrestrial plants must be able to withstand and adapt to wide ranges of temperature (Berry and Bjorkman 1980, Wang et al. 2003, Yamori et al. 2014). This is contrary to the environment experienced by photosynthetic aquatic species in spring/summer in North America; water has a high heat capacity (i.e., the amount of heat required to raise temperature by $1.0^{\circ} \mathrm{C}$ ) (Steeneveld et al. 2014), and so the day-to-day temperature changes in aquatic ecosystems are typically miniscule (ranging from $1.3-2.4^{\circ} \mathrm{C}$ ) compared to that of SAT in terrestrial ecosystems (ranging from $\sim 10.0-15.0^{\circ} \mathrm{C}$ ) (Parton and Logan 1981, Holtby and Newcombe 1982, Beschta et al. 1987, Zhang et al. 2014, Chen et al. 2017). Despite being subjected to greater variation in environmental temperature than aquatic organisms, some cool-season terrestrial plants have exhibited no significant changes in FA content with increasing temperature (Orr and Raison 1987) - similar to perennial ryegrass and smooth bromegrass in my experiment. Therefore, while photosynthetic aquatic organisms have changed their FA profile in response to increasing temperature (Hixson and Arts 2016, Ordog et al. 2016), cool-season terrestrial plant species have had to become able to survive a wider range of temperatures and so they may not be as affected (in terms of FA content and profile), as aquatic organisms, by a $5.5^{\circ} \mathrm{C}$ temperature increase.

Similar to photosynthetic aquatic organisms, pasture plants are primary producers, at the base of the food web, and are therefore a prominent source of nutrients, specifically FA, for domestic and wild herbivores (Power 1992, Wardle et al. 1998). From a FA perspective, the plant species in these trials ranged from 20.0-52.0 $\mu \mathrm{g}$ of total lipid content on average (on a dry weight basis) for the "currentambient" treatment and 41.0-70.0 $\mu \mathrm{g}$ of total lipid content on average (on a dry weight basis) for the "future-warmed" treatment (Table 4.1). These values are relatively high compared to other similar species of Poaceae and Fabaceae, which typically range from 1.0-35.0 $\mu \mathrm{g}$ of total lipid content (on a dry weight basis) (Ezeagu et al. 1998, Bhardwaj et al 2004). Additionally, the EFA content ranged from 5.0-14.0 $\mu \mathrm{g} / \mathrm{mg}$ DW LNA content and 20.0-40.0 $\mu \mathrm{g} / \mathrm{mg}$ DW ALA content, which is also high compared to other studies observing Poaceae and Fabaceae species (e.g., Ezeagu et al. 1998, Dolde et al. 1999, Bhardwaj et al. 2004). Essential FA (i.e., ALA, LNA) and the long-chain FA produced by them (i.e., EPA, DHA, ARA) are selectively retained throughout the food web (Kainz et al. 2006, Glasser et al. 2008), and so temperature-induced changes in FA content and profile, like the ones observed here, have the potential to change the FA content and profile of primary consumers (i.e., herbivores) and subsequently secondary consumers (Morgan et al. 1992, Lock and Bauman 2004, Iverson 2009). Other research examining the effect of increasing air and water temperature on FA in food webs has seen overall decreased nutrition in primary producers (Tremolieres et al 1982, Falcone et al. 2004, Ernst et al. 2016, Saunders et al. 2016). In contrast to these studies, the FA content and profile in my experiment improved from a nutritional 
standpoint; SFA decreased and PUFA (specifically ALA) increased with increasing temperature. Therefore, as the global SAT temperature increases with climate warming, the changes observed in my pasture plants may be reflected in livestock products (i.e., meat and dairy), as well as overall herbivore health.

4.2 Why does temperature have an effect on fatty acid content and profile of forage plants?

My original hypothesis, informed by principles of homeoviscous adaptation, postulated that SFA content would increase, and MUFA and PUFA content would decrease as a result of increasing temperature (Behrouzian and Buist 2002, Nozawa 2011, Ernst et al. 2016, Saunders et al. 2016). Having observed the opposite pattern, I now think that mechanisms other than homeoviscous adaptation (and see below), such as desaturation activity, presence of sterols in the membrane, and/or structural differences (i.e., whether the plant is a monocotyledon or dicotyledon) may also act to govern FA content in terrestrial plants in conjunction with homeoviscous adaptation.

Enzymes known as desaturases are responsible for the insertion of double bonds into SFA to produce MUFA and PUFA in plant cell membranes (Harwood 1980, Stumpf 1980, Los and Murata 1998). Therefore, a change in FA content and profile may be attributed to increased or decreased desaturase activity. Desaturases typically have an optimal functioning temperature range of $20.0-30.0^{\circ} \mathrm{C}$ in temperate land plants (Martin et al. 1976, Garces et al. 1991, Hugley and Somerville 1992). Therefore, desaturase activity in these trials was likely stimulated by increased temperature within the growth chamber. The experimental temperature was manipulated so as to increase from around 8.0 and up to $13.5^{\circ} \mathrm{C}$, which is below the optimal functioning temperature of desaturases. As temperature increased and approached the optimal functioning temperature of desaturases - the enzyme would likely continuously become more effective (Martin et al. 1976, Garces et al. 1991, Hugley and Somerville 1992). The warmest temperature in these trials $\left(13.5^{\circ} \mathrm{C}\right)$ is closer to the optimal $20.0-30.0^{\circ} \mathrm{C}$ range than the coldest temperature $\left(8.0^{\circ} \mathrm{C}\right)$. This may explain why I observed higher relative content of unsaturated FA with increased temperature, contrary to what would be expected based on homeoviscous adaptation alone (Falcone et al. 2004).

Another mechanism that may have been responsible for the unexpected increase in FA content and profile due to temperature is compensatory action by sterols. Sterols are unsaturated steroid alcohols (Alberts et al. 2002) that are important for cell membrane maintenance in plants (Beck et al. 2007), as they stabilize the already-existing FA in the membrane (Piironen et al. 2000). Cool-season pasture plants, 
like the ones observed here, experience a wide range of conditions year-to-year (Marcum 1998) and have therefore developed a wide range of temperature tolerance $\left(10.0-30.0^{\circ} \mathrm{C}\right)$, partially through sterol stabilization (Baker and Jung 1968, Beard 1973). Importantly, sterols are at their highest concentration in plants shortly after germination (Piironen et al. 2000); this is the vegetative phase at which the plants in this study were observed. Perhaps sterols were compensating for the increased membrane fluidity caused by increased temperature through stabilizing FA within the cell membrane. This may have subsequently disallowed a decrease in desaturase activity; i.e. to halt the insertion of double bonds by desaturases, increased fluidity in the cell membrane must be detected by cell membrane proteins (Murata and Los 1997). If sterols were stabilizing the membrane as temperature was increased, desaturase activity may not have decreased as would be expected (Ferguson 1975), leading to continued double bond insertion and therefore decreased relative SFA content, increased relative PUFA content, and higher UI values. This may explain why I observed decreased SFA and increased PUFA, contrary to other studies on terrestrial plant lipid dynamics (Tremolieres et al 1982, Behrouzian and Buist 2002, Upchurch 2008, Nozawa 2011, Ernst et al. 2016, Saunders et al. 2016).

The response of FA content and profile to temperature treatments in this study were speciesspecific as there were no consistent significant trends that were observed in all species collectively. This result is consistent with other studies (Canvin 1964, Bazzaz and Sombroek 1996). Two of the observed species in these trials (white clover and alfalfa) are dicotyledon species while the remaining five species (Kentucky bluegrass, orchardgrass, perennial ryegrass, tall fescue, and smooth bromegrass) are monocotyledon species. Interestingly, both white clover and alfalfa have the added benefit of nitrogen fixation (i.e., conversion of atmospheric nitrogen to usable nitrate in the soil). Dicotyledonous species, like Pisum sativum (pea) and Spinacia oleracea (spinach), have also been seen to have higher unsaturated FA content than monocotyledon species (i.e., barley and corn) (Murphy et al. 1985), which was also observed in white clover and alfalfa in these trials. Additionally, monocotyledonous and dicotyledonous plants differ in their lipid dynamics, namely in their FA synthesis and metabolism. The structure of acetyl-CoA carboxylase (the enzyme responsible for converting acetyl CoA to malonyl CoA at the base of the FA synthesis pathway) is known to differ between monocotyledon and dicotyledon plants, possibly causing the rates of FA synthesis to differ between monocotyledons and dicotyledons (Page et al. 1994, Ohlrogge and Jaworski 1997). Additionally, a comparative study of Arabidopsis (dicotyledon species) and Oryza (monocotyledon species) found significant differences in the genes coding for FA metabolism between these genera (Nelson et al. 2004). The rates of synthesis and breakdown of FA may differ between monocotyledon and dicotyledon species, which could explain the species-specific responses seen in this study (Ohlrogge and Jaworski 1997, Sreenivasulu and Wobus 2013). Therefore, different FA 
dynamics and thus content in monocotyledons and dicotyledons may be partially responsible for the unexpected results observed here.

Collectively, stimulated desaturase activity, sterol compensation, and species-specific response to temperature (in terms of lipid dynamics) may explain why my results do not reflect what would be predicted solely by homeoviscous adaptation. Desaturases, the enzymes responsible for converting SFA to MUFA and PUFA, are most active at 20.0-30.0 ${ }^{\circ} \mathrm{C}$ (Martin et al. 1976, Garces et al. 1991, Hugley and Somerville 1992), and this may be partially why SFA decreased and PUFA increased in most species with temperature in this study. Another mechanism that may explain these unexpected results is compensation by sterols, which is another response to temperature changes (in addition to homeoviscous adaptation) found in plants. Finally, the lack of overarching patterns in all species in this study may also be attributed to differences in lipid dynamics and FA synthesis between monocotyledon and dicotyledon plants.

\subsection{Implications for agriculture and ecosystem dynamics in Southern Ontario}

This experiment provided information to help tease apart the effects of temperature on common forage plants in Southern Ontario. Growing these plants in isolated conditions, in the laboratory, where water, nutrients, humidity, and light levels were controlled allowed me to isolate temperature as a variable and observe its effect on plant growth, FA content, and FA profile. When plants are growing in a natural environment, it is more difficult to separate temperature from the effects of varying precipitation, extreme weather, etc. (Carroll et al. 2001, Pagell et al. 2007). Through this research, I predicted how agricultural forage species responded, from a fatty acid perspective, to an increase in temperature.

All experimental plant species developed faster and grew larger as temperature increased, and this trend was significant for most species. Generally, in plants, development rate and plant size both increase as temperature increases to a certain point (depending on the species, this can range from $15.0-30.0^{\circ} \mathrm{C}$ ) (Morison and Lawlor 1999, Hatfield and Prueger 2015). The specific genera used in these trials showed these same patterns, as development and growth typically peak at $20.0-25.0^{\circ} \mathrm{C}$ and then decline to zero at $\sim 30.0^{\circ} \mathrm{C}$ (Mitchell and Lucanus 1962, Woledge and Jewiss 1969, Peacock 1975, Junttila et al. 1990, Rice et al. 1992, Loveys et al. 2002). Therefore, it is not surprising that growth rate and plant size increased with temperature; the experimental temperature treatment $\left(8.0-13.5^{\circ} \mathrm{C}\right)$ was not hot enough to reach the point of development and growth decline. Interestingly, these same patterns were observed under controlled temperature settings (i.e., in a growth chamber) as well as in the field (Junttila et al. 1990, Hatfield and Prueger 2015). Faster growth and larger plant size was positively correlated with PUFA 
content levels in other photosynthetic species, like maple tree (Mei et al. 2015) and red algae (Cohen et al. 1988). Therefore, the effect of temperature inducing increased growth rate and plant size may be beneficial from a nutritional standpoint.

Overall, evidence suggests that a diet high in PUFA and low in SFA is most nutritious for domestic and wild herbivores (Chilliard et al. 2007, Orhan et al. 2009, Silva et al. 2014) because it contributes to healthy digestion (i.e., reduced biodehydrogenation) and improved fertility (Santos et al. 2008). Additionally, high levels of dietary PUFA, particularly n-3 FA, may provide a range of health benefits in vertebrates, including improved cardiovascular health (Krauss et al. 2000, Mozaffarian and Wu 2011, Endo and Arita 2016), respiratory health (Singer et al. 2006), and brain development and maintenance (Yu et al. 1986, Amminger et al. 2012, Calder 2015). Additionally, the FA content of the plant diet of herbivores is often reflected in the flesh and milk of herbivores themselves (Sanders 2000, Bazinet et al. 2003, Wood et al. 2008). Therefore, plant species with decreased SFA content and increased PUFA content as temperature increases are ideal candidates for agricultural use as climate warming progresses. Increased UI values are also beneficial because high UI values indicates that the overall content of unsaturated (and thus nutritious MUFA and PUFA) FA is increasing with temperature. Based on these trials, alfalfa shows the most promise in this regard; the SFA content of alfalfa increased as temperature approached $12.0^{\circ} \mathrm{C}$ and then decreased beyond this temperature. The $12.0^{\circ} \mathrm{C}$ point was also where PUFA content and UI began to rise in alfalfa, which is beneficial in terms of vertebrate nutrition (Jasuja et al. 2010, Surette 2013). Therefore, in a climate scenario where SAT reaches beyond $12.0^{\circ} \mathrm{C}$, alfalfa will be very beneficial and nutritious in livestock diets during the spring months. Kentucky bluegrass and tall fescue showed similar patterns - to a lesser degree than alfalfa - and may therefore be good options for pastures as climate change progresses. However, the SFA/PUFA ratio increased in tall fescue as temperature increased, which is not ideal for herbivore nutrition (Moyo et al. 2011).

Another important factor to consider for livestock diets is the presence of EFA (i.e., ALA and LNA) in the plant material that is consumed. In herbivores, ALA and LNA act as precursors for longchain unsaturated FA that are crucial for the health and development of vertebrates, namely EPA and DHA, and ARA, respectively (Menard et al. 1998, Bazinet and Laye 2014). Therefore, the effect of temperature on ALA and LNA in pasture plants is important for livestock health and the health of wild herbivores that consume them (e.g., deer, insects, etc.) (Burdge and Calder 2006, Marzetz et al. 2017). Alpha-linolenic acid accounted for between 30.0 to $75.0 \%$ of the total FA in these plant samples, which was somewhat surprising considering that ALA is typically low in terrestrial plants (Orhan et al. 2009, Silva et al. 2014, Marchand et al. 2016, Morris et al. 2018, unpublished). There are potential mechanisms 
to explain why ALA would be uniquely high in pasture plants. In addition to its role in homeviscous adaptation and membrane remodelling, ALA is a precursor for jasmonic acid in plants, which is an important secondary metabolite in plant defense (Davies 2004). Its production is induced by herbivore consumption (Campos et al. 2014); since pasture plants are frequently consumed by wild and domestic herbivores, they may have large stores of ALA to produce jasmonic acid and thus induce defense mechanisms. Alpha-linolenic acid may also be involved in pollen development and dispersion, which is crucial for pasture plant survival and reproduction (McConn and Browse 1996, Manning 2006). A gene knockout study by McConn and Browse (1996) showed that removal of ALA synthesis genes produced plants that were unable to produce and release pollen. Therefore, pasture plants may require large stores of ALA to effectively respond to frequent herbivore damage and to maintain their ability to reproduce.

In this study, I observed that, as temperature increased, white clover significantly increased in LNA content and Kentucky bluegrass significantly increased in ALA content beyond $12.5^{\circ} \mathrm{C}$, which was in contrast to other studies examining the effect of temperature on EFA content (Murakami et al. 2000, Ramezanzadeh et al. 2000). These patterns show promise for herbivore nutrition (Li et al. 1997, Sargent et al. 1998, Murthy et al. 2002, Rao et al. 2007, Bazinet and Laye 2014), and make a strong case for Kentucky bluegrass and white clover as ideal pasture species in the future.

Overall, the species in these trials had relatively high proportions of ALA in their above-ground biomass compared to other terrestrial plant species. This is rare for Poaceae and Fabaceae species because, based on a meta-analysis of 1800 samples of plant species (including many grass and legume species), it was observed that ALA content ranged from $2.0-60.0 \%$ of the total observed FAME (depending on the species, growth stage of the plant, and environmental conditions; Morris et al. 2018, unpublished). However, the plants in this study (five grass species and two legume species) had an average ALA content of $\sim 60.0 \%$ with some samples reaching almost $80.0 \%$ ALA content. When compared to livestock fodder (i.e., food that is provided by farmers and not grazed by the animal), which typically consists of corn and soy (species of Poaceae and Fabaceae, respectively), the proportion of ALA in pasture Poaceae species was 13X higher than fodder Poaceae species, and in pasture Fabaceae species ALA was 5X higher than fodder Fabaceae species (Figure 4.1, Appendix 5.5). This indicates that, regardless of temperature effects, it may be more beneficial to have livestock on a pasture diet versus a fodder diet (Stark et al. 2008, Sanders 2014). In addition to livestock, high ALA levels in pasture plants is also promising for wild herbivores since the plants they are grazing are relatively nutritious according to these trials. 
Although pasture-fed livestock produce more nutritious meat and milk products than fodder-fed livestock (Enser et al. 1998, Ponnampalam 2006, Stark et al. 2008, Sanders 2014), there are challenges facing the pasture industry. Livestock that are raised only on pasture-feed grow and mature slower than those consuming fodder, which may reduce the production rate of pasture farms (Hendrickson and Heffernan 2004, Smith and Lawrence 2008). However, due to lack of fibre content, fodder feeding can make livestock ill due to bacteria in the rumen proliferating and disrupting $\mathrm{pH}$ levels (Owens et al. 1998, Daley et al. 2010). To further complicate matters, this issue is exacerbated when livestock are raised on pasture diets first and then transferred to fodder diets, as they are then more susceptible to illness (Gwin 2009). Pasture feeding also requires more acreage than fodder feeding because two sets of pastures are required (one for female cows and their calves, and the other for male cows) (Smith and Lawrence 2008, Gwin 2009). Therefore, pastures may be beneficial from a nutritional standpoint in terms of FA content, but they may not always be practical in terms of production and resource use.

I observed the absolute content of ALA and LNA in each of my plant samples (on average, 33.4 $\mu \mathrm{g} / \mathrm{mg} \mathrm{DW}$ and $9.3 \mu \mathrm{g} / \mathrm{mg} \mathrm{DW}$, respectively). I used this information, combined with the average dry mass of a plant, to determine ALA and LNA content (in $\mu \mathrm{g}$ ) per acre of pasture. According to OMAFRA (2015), there are $\sim 40$ million seeds planted per acre. Based on my germination rate (98.8\%), this would amount to 39,520,000 plants grown per acre. For each of my six temperature treatments, I used average dry weight to determine ALA and LNA content per plant and multiplied this by the number of plants per acre. Overall, at the lowest temperature for the lowest seeding density (Kentucky bluegrass), I found $~ 2.0$ $\mathrm{kg}$ of ALA per acre and $\sim 0.5 \mathrm{~kg}$ of LNA per acre (Appendix 5.7). These numbers grew as temperature and seeding density increased (orchardgrass, perennial ryegrass, tall fescue, smooth bromgrass) to reach maximum values: $\sim 12.0 \mathrm{~kg}$ of ALA per acre and $\sim 3.0 \mathrm{~kg}$ of LNA per acre. It is clear based on these results that pastures currently hold large stores of EFA which have potential to grow as climate warming increases the growth rate and size of pasture plants. This is promising for the nutrition of wild and domestic herbivores and contributes to the support for a pasture diet in agriculture.

Three species (perennial ryegrass, orchardgrass, and smooth bromegrass) exhibited resilience to changing temperature in these trials (i.e., they did not show a significant change in FA content or profile), similar to other cool-season pasture plants (Orr and Raison 1987, Narayanan et al. 2016). Perennial ryegrass is native to Southern Ontario and so it may have an advantage in that it is adapted to this temperate environment and therefore does not need to acclimatize to the conditions. Plants that are native to warm climates show dramatic changes in their FA composition when transplanted to temperate climates (Wilson and Crawford 1974) versus those that are native to temperate environments, which show 
minor changes (Smolenska and Kuiper 1977). However, a lack of change in FA composition in response to temperature may limit the range of survivability in some species; orchardgrass and smooth bromegrass are the only species in this study that do not grow outside of North America. Although not well-studied in plants, other organisms have been observed in terms of FA composition and range limits. For example, honeycomb worms that showed changes in the FA composition of their cell membrane (as per the principles of homeoviscous adaptation) were better able to survive increasing temperatures than those which did not show changes (Muir et al. 2016). This same pattern has been observed in red algae (Luo et al. 2014), as well as scallops, oysters, and mussels (Hall et al. 2002, Pernet et al. 2007). Due to their relatively consistent FA content in response to temperature, perennial ryegrass, orchardgrass, and smooth bromegrass may be options for pastures as climate warming progresses, but because there were other species in this study that appeared to have improved nutrition with increasing temperature, it may be more advantageous to use these species (i.e., Kentucky bluegrass, white clover, alfalfa) in the future.

Additionally, consistent FA content in response to temperature may be range-limiting for orchardgrass and smooth bromegrass.

\subsection{Limitations and future work}

Although it is important to tease apart the effects of temperature on the FA content and profile of forage plants in Southern Ontario, climate change is also expected to increase precipitation and incidences of extreme weather in this geographical area, as well as across North America (IPCC 2014, Karl et al. 2015). Future work should thus include more ecologically-representative experimental treatments that attempt to observe combined effects of increased temperature, rainfall, and extreme weather patterns. This would produce a more comprehensive study of how climate change, as a whole, will affect the development, growth, and FA content of forage plants.

Some of my results (i.e., unchanged FA content with increasing temperature) may be explained by a compensatory mechanism by sterols within the cell membrane in my plant species (Ferguson et al. 1975, Piironen et al. 2000). Therefore, it may be interesting to examine the effects of temperature on sterol content, in addition to observing the FA content and profile. Stabilization of the cell membrane by sterols may be specific to cool-season pasture plants (Baker and Jung 1968, Beard 1973), and so future studies may consider comparing FA and sterol content between cool-season pasture plants versus warmseason pasture plants (e.g., Andropogon spp., Sorghastrum nutans). This will help determine if coolseason and warm-season pasture plants behave differently in response to temperature and may aid in species selection in the face of climate warming. 
It may be beneficial to further expand the breadth of knowledge in the scientific literature by observing the effects of controlled temperature on other prominent forage species in Southern Ontario, such as timothy grass (Phleum pratense) and red clover (Trifolium pratense), which are both highly recommended for use in Southern Ontario pastures (OMAFRA 2015). An in-depth look at the effect of temperature on monocotyledon versus dicotyledon plant species in terms of growth and FA production may confirm the initial observations in this study, as the dicotyledonous species in these trials (i.e., white clover and alfalfa) show promise for maintaining healthy livestock as climate warming progresses.

In this study, I used sterile soil media to grow my plants. However, I may have obtained different results had I used natural soil sources. Plants - like soybean, pea, petunia, and maize - have the ability to uptake fatty acids through their roots (Terzaghi 1989). Soil bacteria (Janben and Steinbuchel 2014) and fungi have been seen to produce fatty acids, which are then made available to plant roots (Yoshida et al. 2016, Luginbuehl et al. 2017). Additionally, white clover and alfalfa can form nitrogen-fixing symbioses with bacteria that improves nutrient uptake in their roots (Urquiaga et al. 1990). Therefore, the FA content has potential to differ in plants grown in natural soil versus sterile soil. Future projects should include soil type (natural versus sterile) as an independent variable, in addition to temperature, when studying FA content and composition in pasture plants.

Future work may build on these results to guide a feeding experiment comparing the FA content and profile of herbivores - such as cattle, deer, and insects - that have been fed "current-ambient" grown forage plants versus "future-warmed" grown forage plants. There is evidence to suggest that the relative FA content and profile in primary producers is reflected in the primary consumers that ingest them (Muller-Navarra 2000, Sanders 2000, Bazinet et al. 2003, Wood et al. 2008). This type of experiment could determine if, and to what degree, the FA content and profile of herbivores will be affected by forage plant exposure to climate warming temperatures, thereby adding to the body of knowledge of climate change adaptation and nutrition throughout agricultural food webs.

\section{$\underline{4.5 \text { Conclusions }}$}

In conclusion, climate warming in Southern Ontario has potential to affect the growth, FA content and FA profile of many forage plant species. However, responses are species-specific and therefore must be examined on a species-by-species basis in the future. Contrary to my predictions, I saw decreased SFA content and increased PUFA content with increased temperature. Some species showed increases in EFA 
with temperature, which was also unexpected. By taking advantage of these plant qualities in the face of climate warming, farmers might be able to maintain (and possibly improve) the health and nutrition of livestock - and wild grazing herbivores - which could, in turn, maintain healthy ecosystem dynamics within the agricultural food web, including the health of meat-consuming humans. It is important that this information be effectively conveyed to farmers and policymakers alike, through multi-disciplinary conferences, pasture production reports, and governmental recommendations in Southern Ontario.

Table 4.1: Average total lipid content $( \pm \mathrm{SD})$ of the seven species observed in these trials under "currentambient" and "future-warmed" conditions which were measured by gravimetric analysis.

\begin{tabular}{ccc}
\hline \hline Species & \multicolumn{2}{c}{ Average total lipid $(\boldsymbol{\mu g} \pm \mathbf{S D})$} \\
& Current-ambient & Future-warmed \\
\hline Kentucky bluegrass & $45.6 \pm 0.02$ & $51.2 \pm 0.02$ \\
Orchardgrass & $52.0 \pm 0.02$ & $69.6 \pm 0.03$ \\
Perennial ryegrass & $51.0 \pm 0.03$ & $61.2 \pm 0.02$ \\
White clover & $32.6 \pm 0.01$ & $49.0 \pm 0.05$ \\
Tall fescue & $27.6 \pm 0.01$ & $54.3 \pm 0.03$ \\
Alfalfa & $20.4 \pm 0.01$ & $41.1 \pm 0.02$ \\
Smooth bromegrass & $36.4 \pm 0.01$ & $57.9 \pm 0.06$ \\
\hline
\end{tabular}




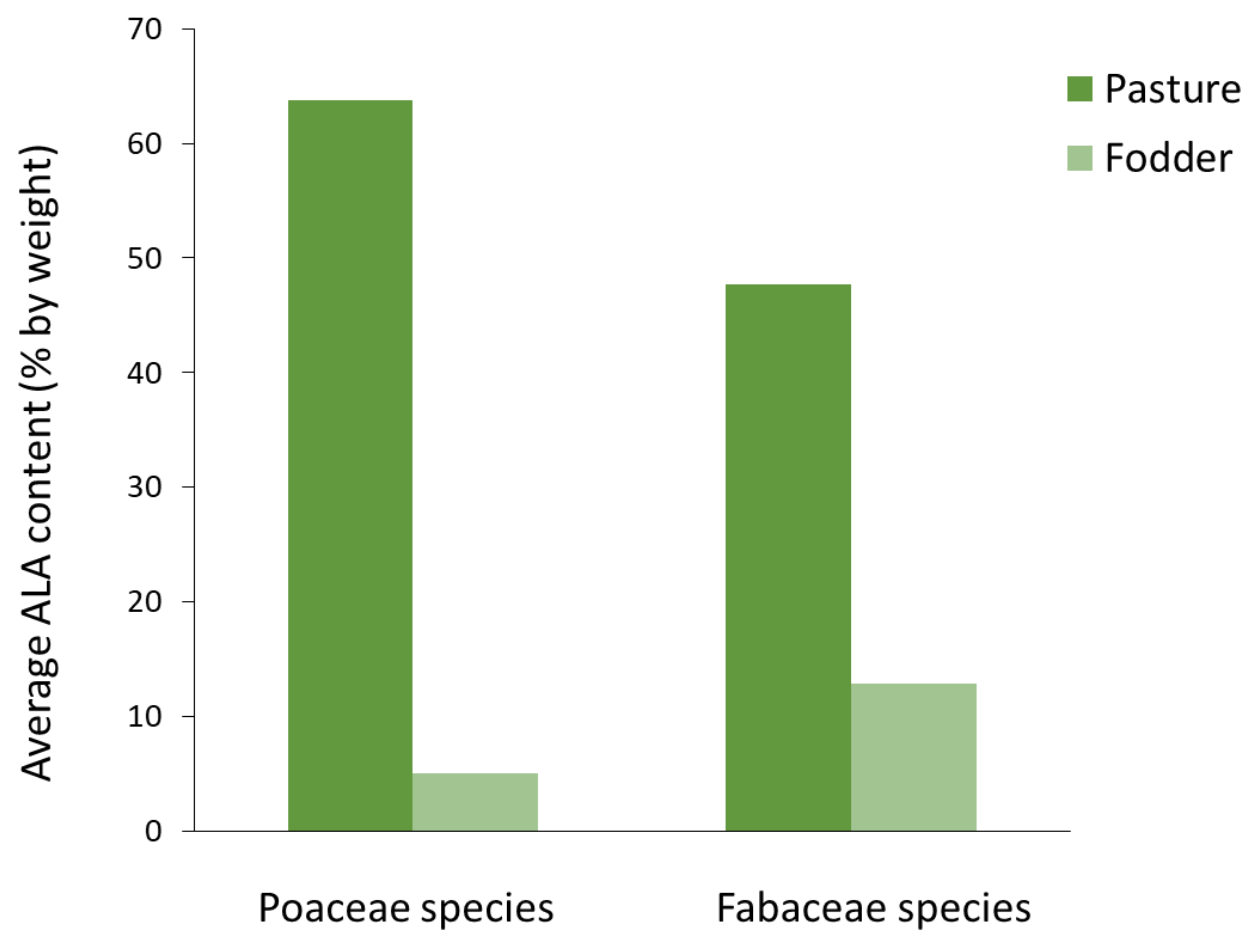

Figure 4.1: A comparison of average ALA content (\% by weight $\pm 95 \% \mathrm{CI}$ ) of pasture Poaceae species $(\mathrm{N}=107)$ and pasture Fabaceae species $(\mathrm{N}=36)$ - as observed in these trials - versus fodder Poaceae species ( $N=24)$ and fodder Fabaceae (N=59) species; pasture species are represented by the seven species used in these trials versus fodder species, which are grown to use as livestock feed (i.e., corn and soy). 


\section{Appendix}

Appendix 5.1: Standard operating procedure for using potting soil in cone-tainers at Ryerson Medical Facility.

Standard Operating Procedure: Planting experiment using Premier Tech Potting Soil in RMF VWR chamber

1. Purpose: to provide step by step guidance for working with Premier Tech Potting Soil for Home and Garden (product \#4906001, \#4907561, \#4907571) at RMF in the VWR chamber (model 2015-2)

2. Scope: applies to all PIs and trainees

3. Prerequisites: PI: possession of biohazard certificate with IRM. Trainees: IRM training Biohazard \& WHMIS. RMF-SS training.

4. Responsibilities:

Maintain a clean work space and lab space during the process of potting.

Properly clean up and dispose of used soil.

5. Personal Protection Equipment (PPE):

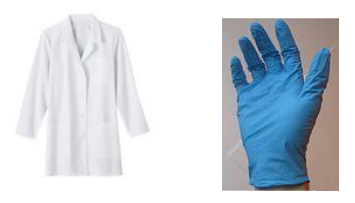

\section{Procedure:}

Consultation with Premier Tech confirms that potting soil is sterilized before packaging.

Place bag of potting soil in a secondary container.

Place plastic tray at the very bottom of the chamber (to catch water and soil particles).

Place plastic tray on work bench and line with garbage bag (Kirkland garbage bags work well). 
Fill cone-tainers with soil and dampen.

Place seed on top of soil.

Sprinkle seed with thin layer of soil and dampen again.

Transport cone-tainers to the chamber in a tray (to avoid dropping soil on the floor).

Place cone-tainers in chamber using shelves as "trays" to hold cone-tainers vertically.

Clean work area (see below).

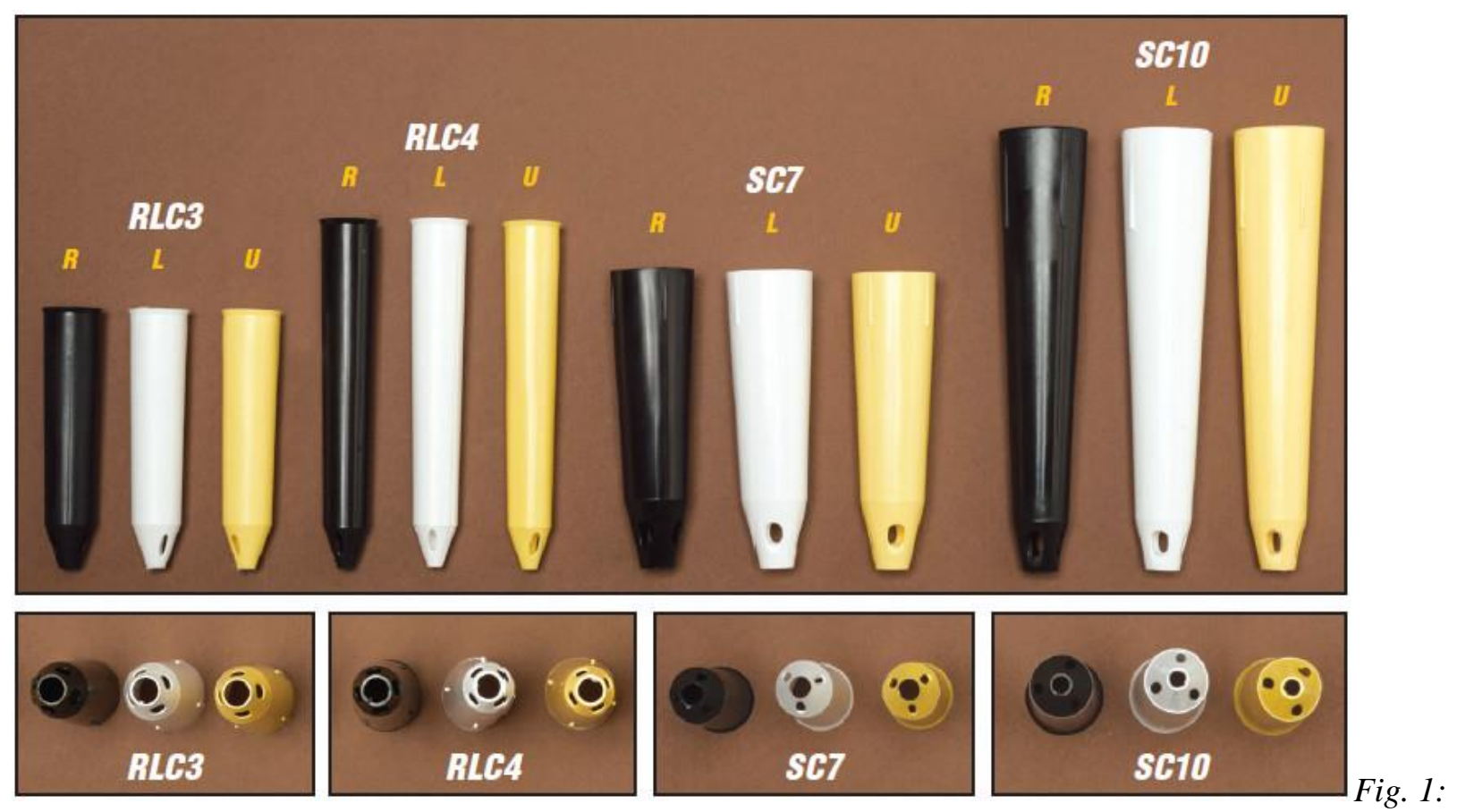

Cone-tainers of different sizes. 


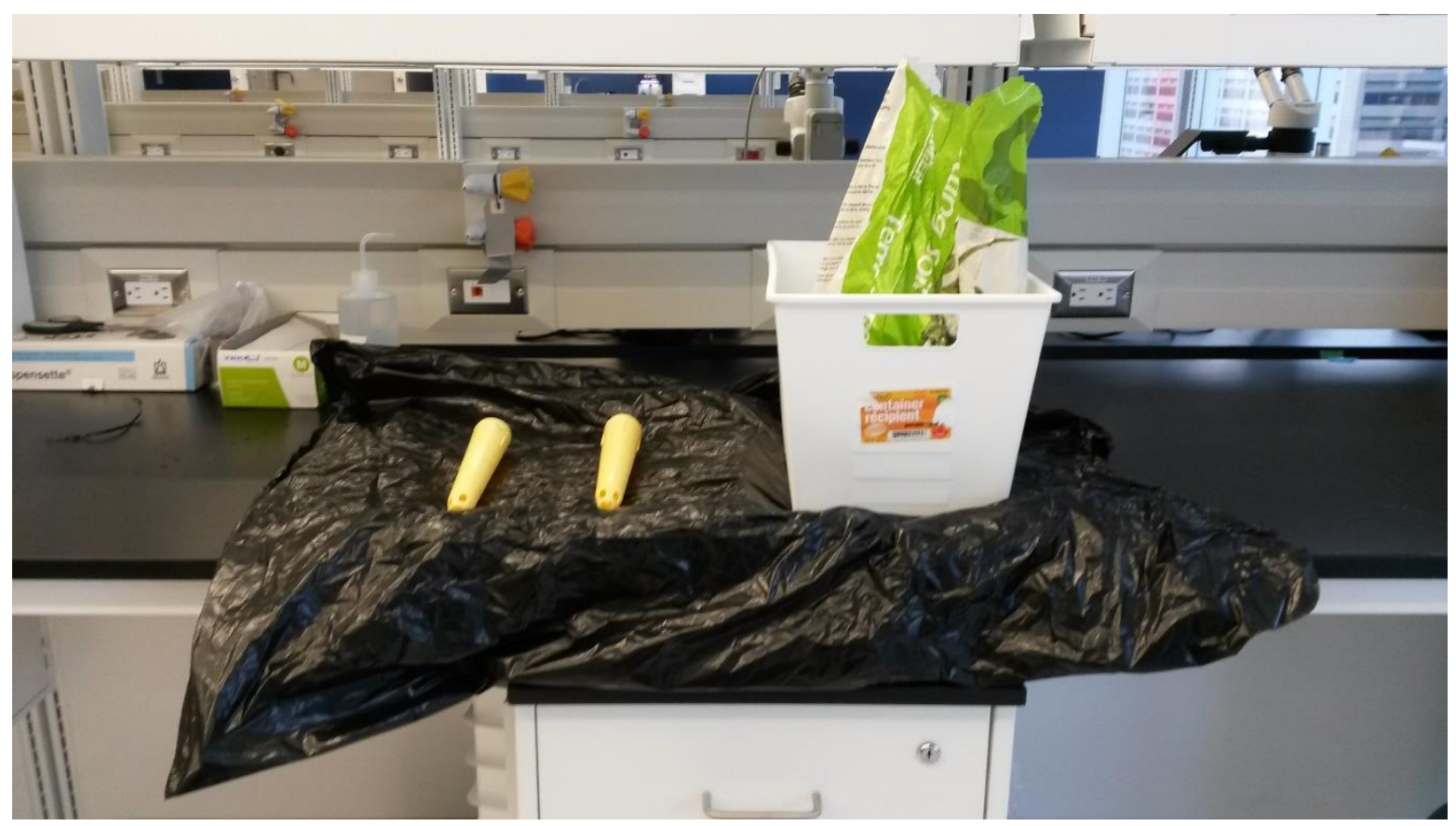

Fig. 2: Potting set-up.

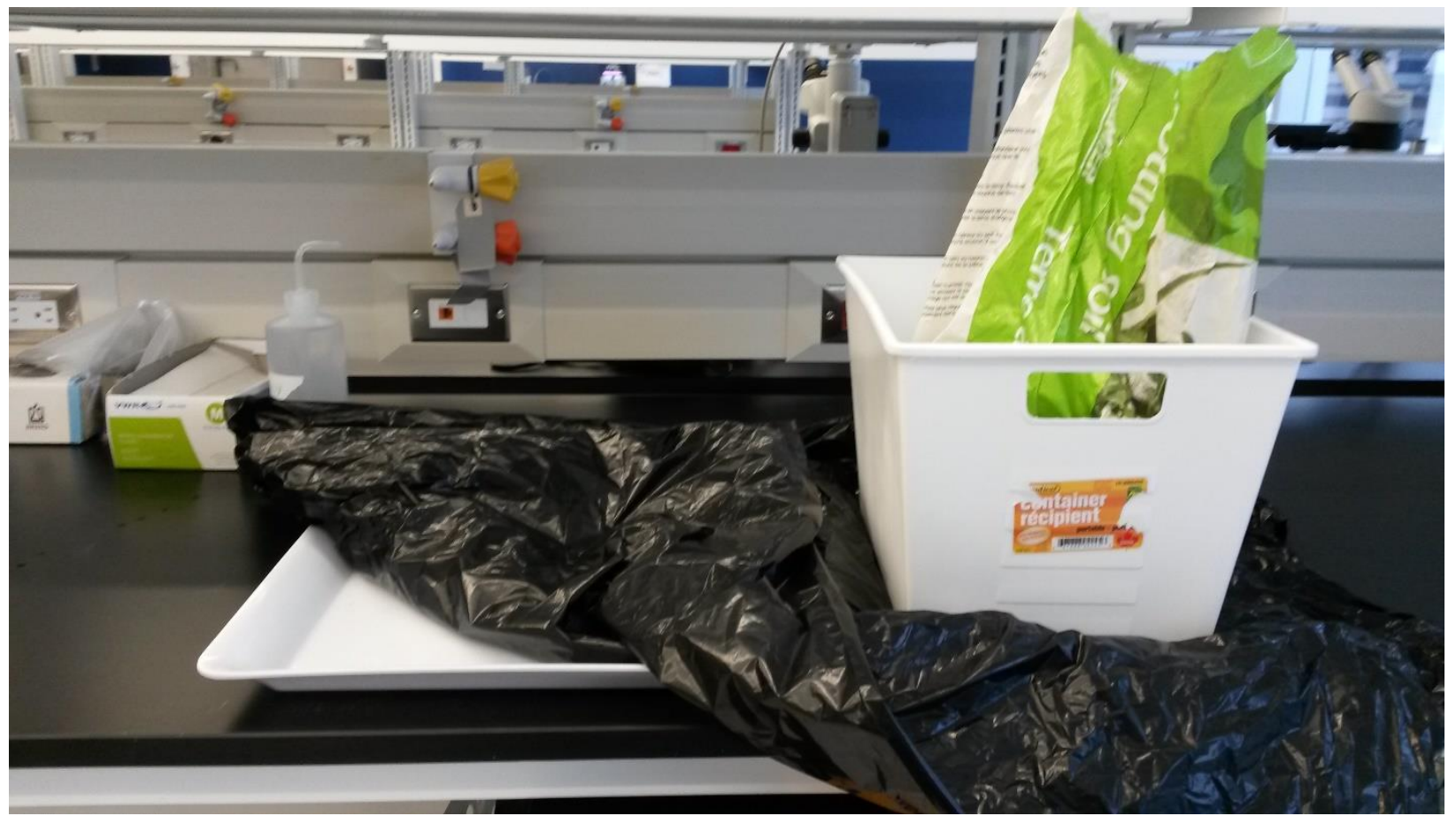

Fig. 3: Potting set-up showing tray underneath garbage bag. 


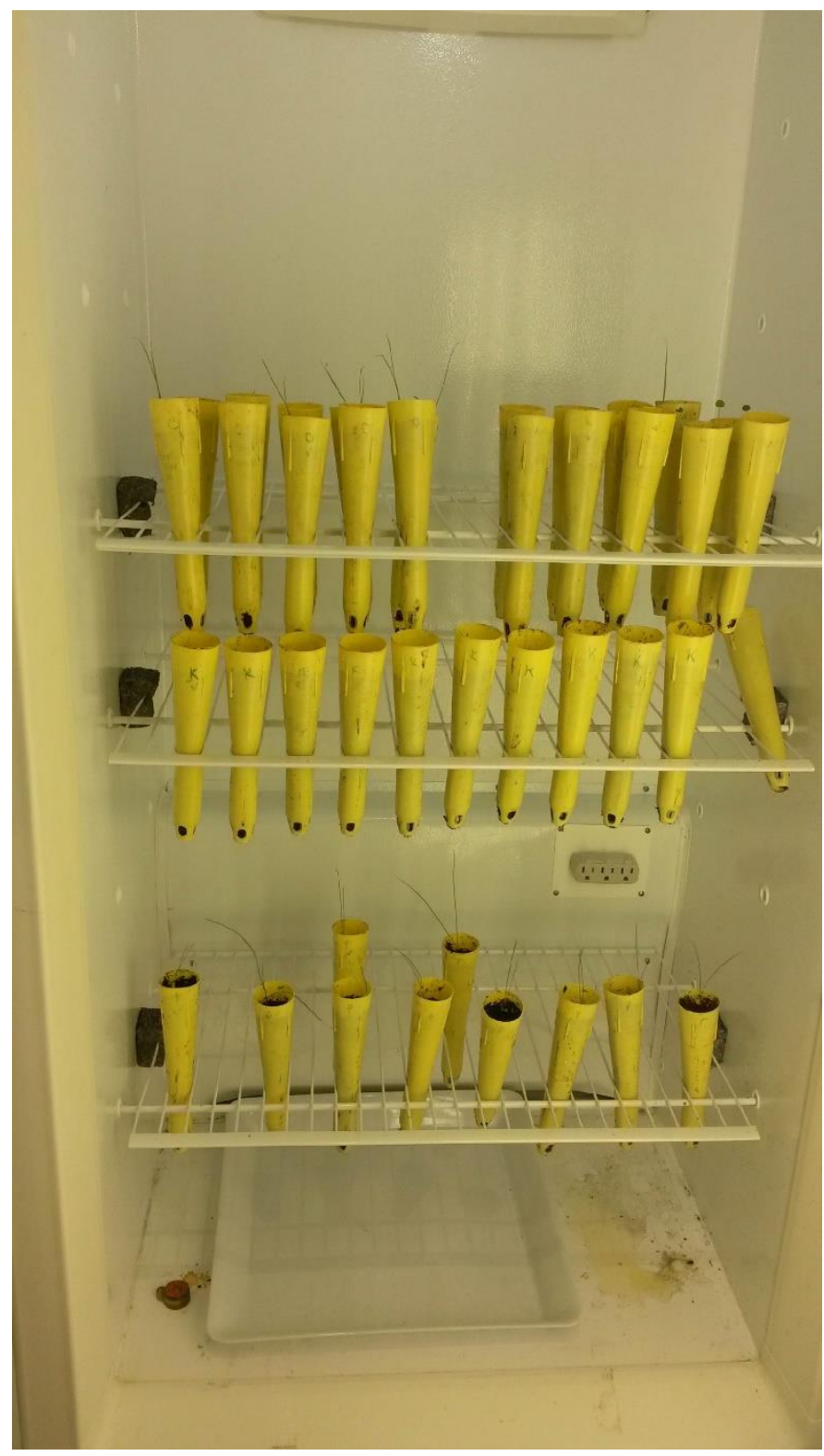

Fig. 4: Set-up of containers and tray inside the chamber

\section{Procedure for cleanup:}

Close bag of potting soil with a clip or twist-tie.

Dispose of workspace liners in regular waste bin.

Clean all trays with soap and water.

Wipe down counters and sweep floor if necessary

Wash hands. 
Appendix 5.2: List of abbreviations.

\begin{tabular}{|c|c|}
\hline Abbreviation & Full word \\
\hline ALA & Alpha-linolenic acid \\
\hline CLA & Conjugated linoleic acid \\
\hline ECCC & Environment and Climate Change Canada \\
\hline FA & Fatty acid \\
\hline IPCC & International Panel on Climate Change \\
\hline LNA & Linoleic acid \\
\hline MUFA & Monounsaturated fatty acid \\
\hline OMAFRA & Ontario Ministry of Agriculture and Rural Affairs \\
\hline PUFA & Polyunsaturated fatty acid \\
\hline $\mathrm{RCP}$ & Representative concentration pathway \\
\hline SAT & Surface air temperature \\
\hline SFA & Saturated fatty acid \\
\hline UI & Unsaturation index \\
\hline
\end{tabular}


Appendix 5.3: Summary of MANOVA and ANOVA results for temperature effects on various response variables; the first row of response variables is associated with chamber effects (high versus low) while the second row is associated with shelf effects (1-6): ns, $\mathrm{P}>0.05 ; *, \mathrm{P}<0.05 ; * *, \mathrm{P}<0.01$; ***, $\mathrm{P}<$ 0.001 .

\begin{tabular}{|c|c|c|c|c|c|c|c|}
\hline $\begin{array}{l}\text { Response } \\
\text { variable }\end{array}$ & $\mathrm{df}$ & $\begin{array}{l}\mathrm{F}_{\text {Kentucky }} \\
\text { bluegrass }\end{array}$ & $\mathrm{F}_{\text {orchardgrass }}$ & $\mathrm{F}_{\text {white clover }}$ & $\mathrm{F}_{\text {tall fescue }}$ & $\mathrm{F}_{\text {alfalfa }}$ & $\begin{array}{l}\mathrm{F}_{\text {smooth }} \\
\text { bromegrass }\end{array}$ \\
\hline Development & 1 & $595.79 * * *$ & $41.56^{* * *}$ & $46.64 * * *$ & $648.68 * * *$ & $527.34 * * *$ & $40.52 * * *$ \\
\hline $\begin{array}{l}\text { (days to two- } \\
\text { leaf phase) }\end{array}$ & 1 & $5.74 *$ & $46.14 * * *$ & $50.16^{* * *}$ & $75.58 * * *$ & $19.14 * * *$ & $45.27 * * *$ \\
\hline \multirow[t]{2}{*}{ Wet mass } & 1 & $3.75^{\mathrm{ns}}$ & $23.30 * * *$ & $44.81 * * *$ & $100.46^{* * *}$ & $81.27 * * *$ & $41.58 * * *$ \\
\hline & 1 & $39.89 * * *$ & $21.88 * * *$ & $29.14 * * *$ & $3.21^{\mathrm{ns}}$ & $6.79 *$ & $0.67^{\mathrm{ns}}$ \\
\hline \multirow[t]{3}{*}{ Dry mass } & 1 & $0.71^{\mathrm{ns}}$ & $16.17 * * *$ & $40.23 * * *$ & $68.06 * * *$ & $36.05^{* * *}$ & $22.79 * * *$ \\
\hline & 1 & $66.53 * * *$ & $64.73 * * *$ & $36.17 * * *$ & $5.63^{*}$ & $19.30 * * *$ & $0.51^{\mathrm{ns}}$ \\
\hline & $\overline{\mathrm{df}}$ & $\begin{array}{l}\mathrm{F}_{\text {Kentucky }} \\
\text { bluegrass }\end{array}$ & $\mathrm{F}_{\text {orchardgrass }}$ & 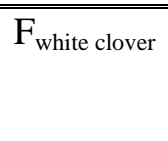 & $\mathrm{F}_{\text {tall fescue }}$ & $\overline{\mathrm{F}_{\text {alfalfa }}}$ & $\begin{array}{l}\mathrm{F}_{\text {smooth }} \\
\text { bromegrass }\end{array}$ \\
\hline $\begin{array}{l}\text { Hotelling- } \\
\text { Lawley Trace }\end{array}$ & 16 & $6.79 * *$ & $2.59 *$ & $2.15^{\mathrm{ns}}$ & $5.79 * *$ & $1.98^{\mathrm{ns}}$ & $1.97^{\mathrm{ns}}$ \\
\hline
\end{tabular}




\begin{tabular}{|c|c|c|c|c|c|c|c|}
\hline $\begin{array}{l}\text { Response } \\
\text { variable }\end{array}$ & $\overline{\mathrm{df}}$ & $\begin{array}{l}F_{\text {Kentucky }} \\
\text { bluegrass }\end{array}$ & $\mathrm{F}_{\text {orchardgrass }}$ & $\overline{F_{\text {white clover }}}$ & $\overline{F_{\text {tall fescue }}}$ & $\overline{F_{\text {alfalfa }}}$ & 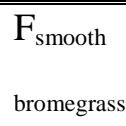 \\
\hline \multirow[t]{2}{*}{ SFA } & 1 & $21.92 * * *$ & $21.56^{* * *}$ & $3.38^{\mathrm{ns}}$ & $4.52^{\mathrm{ns}}$ & $0.76^{\mathrm{ns}}$ & $1.03^{\mathrm{ns}}$ \\
\hline & 1 & $17.52 * *$ & $7.69 *$ & $0.96^{\mathrm{ns}}$ & $3.64^{\mathrm{ns}}$ & $1.72^{\mathrm{ns}}$ & $6.90^{\mathrm{ns}}$ \\
\hline \multirow[t]{2}{*}{ MUFA } & 1 & $4.99 *$ & $26.72 * * *$ & $1.56^{\mathrm{ns}}$ & $2.99^{\mathrm{ns}}$ & $1.04^{\mathrm{ns}}$ & $0.01^{\mathrm{ns}}$ \\
\hline & 1 & $1.83^{\mathrm{ns}}$ & $0.14^{\mathrm{ns}}$ & $10.10 * *$ & $3.40^{\mathrm{ns}}$ & $0.90^{\mathrm{ns}}$ & $0.18^{\mathrm{ns}}$ \\
\hline \multirow[t]{2}{*}{ PUFA } & 1 & $9.19 * *$ & $8.02 *$ & $8.25^{*}$ & $3.15^{\mathrm{ns}}$ & $1.58^{\mathrm{ns}}$ & $1.03^{\mathrm{ns}}$ \\
\hline & 1 & $18.43 * * *$ & $10.01 * *$ & $2.53^{\mathrm{ns}}$ & $6.36^{*}$ & $4.28^{\mathrm{ns}}$ & $7.53^{\mathrm{ns}}$ \\
\hline \multirow[t]{3}{*}{ SFA/PUFA } & 1 & $9.47 * *$ & $3.86^{\mathrm{ns}}$ & $0.72^{\mathrm{ns}}$ & $0.002^{\mathrm{ns}}$ & $3.50^{\mathrm{ns}}$ & $1.80^{\mathrm{ns}}$ \\
\hline & 1 & $6.09 *$ & $5.24 *$ & $6.55^{*}$ & $10.29^{\mathrm{ns}}$ & $11.02 * *$ & $2.30^{\mathrm{ns}}$ \\
\hline & $\overline{d f}$ & $\begin{array}{l}\mathrm{F}_{\text {Kentucky }} \\
\text { bluegrass }\end{array}$ & $\mathrm{F}_{\text {orchardgrass }}$ & $\overline{F_{\text {white clover }}}$ & $\overline{F_{\text {tall fescue }}}$ & $\overline{F_{\text {alfalfa }}}$ & $\begin{array}{l}\mathrm{F}_{\text {smooth }} \\
\text { bromegrass }\end{array}$ \\
\hline $\begin{array}{l}\text { Hotelling- } \\
\text { Lawley Trace }\end{array}$ & 16 & $6.08 * *$ & $2.33^{\mathrm{ns}}$ & $2.52^{\mathrm{ns}}$ & $5.76^{* *}$ & $3.03 *$ & $3.29 *$ \\
\hline
\end{tabular}




\begin{tabular}{|c|c|c|c|c|c|c|c|}
\hline $\begin{array}{l}\text { Response } \\
\text { variable }\end{array}$ & $\overline{d f}$ & $\begin{array}{l}\mathrm{F}_{\text {Kentucky }} \\
\text { bluegrass }\end{array}$ & $\mathrm{F}_{\text {orchardgrass }}$ & $\overline{F_{\text {white clover }}}$ & $\overline{F_{\text {tall fescue }}}$ & $\overline{F_{\text {alfalfa }}}$ & $\begin{array}{l}\mathrm{F}_{\text {smooth }} \\
\text { bromegrass }\end{array}$ \\
\hline \multirow[t]{2}{*}{ SFA } & 1 & $8.91 *$ & $3.68^{\mathrm{ns}}$ & $0.27^{\mathrm{ns}}$ & $0.05^{\mathrm{ns}}$ & $3.61^{\mathrm{ns}}$ & $2.02^{\mathrm{ns}}$ \\
\hline & 1 & $4.17^{\mathrm{ns}}$ & $4.38 *$ & $3.92^{\mathrm{ns}}$ & $11.20^{*}$ & $8.02 *$ & $1.93^{\mathrm{ns}}$ \\
\hline \multirow[t]{2}{*}{ MUFA } & 1 & $0.36^{\mathrm{ns}}$ & $4.84^{*}$ & $0.01^{\mathrm{ns}}$ & $0.18^{\mathrm{ns}}$ & $0.44^{\mathrm{ns}}$ & $9.95 * *$ \\
\hline & 1 & $5.76^{*}$ & $47.76^{* * *}$ & $14.82 * *$ & $0.18^{\mathrm{ns}}$ & $16.34 * *$ & $13.31 * *$ \\
\hline \multirow[t]{2}{*}{ PUFA } & 1 & $6.7^{*}$ & $4.54^{\mathrm{ns}}$ & $4.31 *$ & $0.10^{\mathrm{ns}}$ & $2.47^{\mathrm{ns}}$ & $1.21^{\mathrm{ns}}$ \\
\hline & 1 & $12.73 * *$ & $9.17 * *$ & $11.81^{*}$ & $9.19^{\mathrm{ns}}$ & $16.59 * *$ & $5.83^{*}$ \\
\hline \multirow[t]{3}{*}{ SFA/PUFA } & 1 & $9.68 * *$ & $3.86^{\mathrm{ns}}$ & $1.64^{\mathrm{ns}}$ & $0.002^{\mathrm{ns}}$ & $3.50^{\mathrm{ns}}$ & $1.78^{\mathrm{ns}}$ \\
\hline & 1 & $6.56^{*}$ & $5.24 *$ & $7.92^{\mathrm{ns}}$ & $10.29^{\mathrm{ns}}$ & $11.02 * *$ & $2.45^{\mathrm{ns}}$ \\
\hline & $\overline{d f}$ & $\begin{array}{l}\mathrm{F}_{\text {Kentucky }} \\
\text { bluegrass }\end{array}$ & $\mathrm{F}_{\text {orchardgrass }}$ & $\overline{F_{\text {white clover }}}$ & $\overline{F_{\text {tall fescue }}}$ & $\overline{F_{\text {alfalfa }}}$ & $\begin{array}{l}\mathrm{F}_{\text {smooth }} \\
\text { bromegrass }\end{array}$ \\
\hline $\begin{array}{l}\text { Hotelling- } \\
\text { Lawley Trace }\end{array}$ & 24 & $5.16^{*}$ & $5.00 * *$ & $13.69 *$ & $9.78 * * *$ & $3.49 *$ & $3.96^{*}$ \\
\hline
\end{tabular}




\begin{tabular}{|c|c|c|c|c|c|c|c|}
\hline $\begin{array}{l}\text { Response } \\
\text { variable }\end{array}$ & $\overline{\mathrm{df}}$ & $\begin{array}{l}\mathrm{F}_{\text {Kentucky }} \\
\text { bluegrass }\end{array}$ & $\mathrm{F}_{\text {orchardgrass }}$ & F $F_{\text {white clover }}$ & 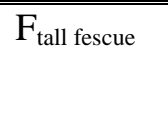 & $\overline{\mathrm{F}_{\text {alfalfa }}}$ & 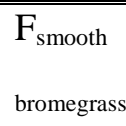 \\
\hline \multirow[t]{2}{*}{$15: 0$} & 1 & $27.49 * * *$ & $25.48 * * *$ & $0.002^{\mathrm{ns}}$ & $19.51 * * *$ & $0.49^{\text {ns }}$ & $5.55^{*}$ \\
\hline & 4 & $1.32^{\mathrm{ns}}$ & $2.93^{\mathrm{ns}}$ & $9.82^{\mathrm{ns}}$ & $2.81^{\mathrm{ns}}$ & $3.00^{\mathrm{ns}}$ & $0.12^{\mathrm{ns}}$ \\
\hline \multirow[t]{2}{*}{$16: 0$} & 1 & $30.73 * * *$ & $17.7^{* *}$ & $0.01^{\mathrm{ns}}$ & $9.43 * *$ & $1.22^{\mathrm{ns}}$ & $0.24^{\mathrm{ns}}$ \\
\hline & 4 & $0.40^{\mathrm{ns}}$ & $2.48 \mathrm{~ns}$ & $1.05^{\mathrm{ns}}$ & $1.29^{\mathrm{ns}}$ & $1.23^{\mathrm{ns}}$ & $0.59^{\mathrm{ns}}$ \\
\hline \multirow[t]{2}{*}{ 18:0 } & 1 & $31.84 * * *$ & $8.36^{*}$ & $0.02^{\mathrm{ns}}$ & $4.12^{\mathrm{ns}}$ & $1.32^{\mathrm{ns}}$ & $0.36^{\mathrm{ns}}$ \\
\hline & 4 & $7.34 * *$ & $3.63^{*}$ & $11.34 *$ & $2.06^{\mathrm{ns}}$ & $1.13^{\mathrm{ns}}$ & $2.54^{\mathrm{ns}}$ \\
\hline \multirow[t]{2}{*}{$18: 1 \mathrm{n}-9 \mathrm{c}$} & 1 & $16.40 * *$ & $3.25 \mathrm{~ns}$ & $13.14 * *$ & $11.01 * *$ & $9.27 *$ & $0.22^{\mathrm{ns}}$ \\
\hline & 4 & $3.32^{\mathrm{ns}}$ & $1.80 \mathrm{~ns}$ & $3.48 *$ & $1.14^{\mathrm{ns}}$ & $3.86^{*}$ & $0.17^{\mathrm{ns}}$ \\
\hline \multirow[t]{2}{*}{ LNA } & 1 & $34.53 * * *$ & $23.87 * * *$ & $2.96^{\mathrm{ns}}$ & $6.06^{*}$ & $0.05^{\mathrm{ns}}$ & $0.03^{\mathrm{ns}}$ \\
\hline & 4 & $1.69^{\mathrm{ns}}$ & $2.31 \mathrm{~ns}$ & $12.56^{*}$ & $1.53^{\mathrm{ns}}$ & $1.06^{\mathrm{ns}}$ & $2.00^{\mathrm{ns}}$ \\
\hline \multirow[t]{3}{*}{ ALA } & 1 & $29.44 * * *$ & $17.26^{* *}$ & $7.63 *$ & $10.92 * *$ & $2.67^{\mathrm{ns}}$ & $0.29^{\mathrm{ns}}$ \\
\hline & 4 & $1.23^{\mathrm{ns}}$ & $1.67 \mathrm{~ns}$ & $5.98 * *$ & $0.99^{\text {ns }}$ & $8.51^{\mathrm{ns}}$ & $0.65^{\mathrm{ns}}$ \\
\hline & $\overline{d f}$ & $\begin{array}{l}\mathrm{F}_{\text {Kentucky }} \\
\text { bluegrass }\end{array}$ & $\mathrm{F}_{\text {orchardgrass }}$ & $\mathrm{F}_{\text {white clover }}$ & $\mathrm{F}_{\text {tall fescue }}$ & $\overline{F_{\text {alfalfa }}}$ & $\begin{array}{l}\mathrm{F}_{\text {smooth }} \\
\text { bromegrass }\end{array}$ \\
\hline Hotelling- & 12 & $4.38 * *$ & $10.53 * * *$ & $2.81 *$ & $6.87 * * *$ & $9.68 * * *$ & $3.95^{*}$ \\
\hline Lawley Trace & & & & & & & \\
\hline
\end{tabular}




\begin{tabular}{|c|c|c|c|c|c|c|c|}
\hline $\begin{array}{l}\text { Response } \\
\text { variable }\end{array}$ & $\overline{d f}$ & $\begin{array}{l}\mathrm{F}_{\text {Kentucky }} \\
\text { bluegrass }\end{array}$ & " $\mathrm{F}_{\text {orchardgrass }}$ & $\mathrm{F}_{\text {white clover }}$ & $\overline{F_{\text {tall fescue }}}$ & $\mathrm{F}_{\text {alfalfa }}$ & $\begin{array}{l}\mathrm{F}_{\text {smooth }} \\
\text { bromegrass }\end{array}$ \\
\hline \multirow[t]{2}{*}{$15: 0$} & 1 & $2.93^{\mathrm{ns}}$ & $6.40^{*}$ & $1.35^{\mathrm{ns}}$ & $1.03^{\mathrm{ns}}$ & $0.01^{\mathrm{ns}}$ & $18.53 * *$ \\
\hline & 4 & $0.57^{\mathrm{ns}}$ & $4.67 *$ & $0.58^{\mathrm{ns}}$ & $1.74^{\mathrm{ns}}$ & $1.03^{\mathrm{ns}}$ & $1.50^{\mathrm{ns}}$ \\
\hline \multirow[t]{2}{*}{$16: 0$} & 1 & $1.78^{\mathrm{ns}}$ & $5.90^{*}$ & $0.02^{\mathrm{ns}}$ & $0.02^{\mathrm{ns}}$ & $2.91^{\mathrm{ns}}$ & $0.39^{\mathrm{ns}}$ \\
\hline & 4 & $12.06 * * *$ & $8.46^{\mathrm{ns}}$ & $6.08^{\mathrm{ns}}$ & $11.15^{*}$ & $2.04^{\mathrm{ns}}$ & $5.19 *$ \\
\hline \multirow[t]{2}{*}{ 18:0 } & 1 & $0.33^{\mathrm{ns}}$ & $0.05^{\mathrm{ns}}$ & $0.05^{\mathrm{ns}}$ & $7.28 *$ & $3.95^{*}$ & $0.01^{\mathrm{ns}}$ \\
\hline & 4 & $9.59^{\mathrm{ns}}$ & $1.61^{\mathrm{ns}}$ & $10.17^{\mathrm{ns}}$ & $4.24 *$ & $14.92 *$ & $3.22^{\mathrm{ns}}$ \\
\hline \multirow[t]{2}{*}{$18: 1 n-9 c$} & 1 & $2.08^{\mathrm{ns}}$ & $10.96 * * *$ & $35.56 * * *$ & $0.10^{\mathrm{ns}}$ & $3.11^{\mathrm{ns}}$ & $0.12^{\mathrm{ns}}$ \\
\hline & 4 & $7.80^{\mathrm{ns}}$ & $12.63^{*}$ & $2.47^{\mathrm{ns}}$ & $4.32^{\mathrm{ns}}$ & $1.87^{\mathrm{ns}}$ & $13.68 * * *$ \\
\hline \multirow[t]{2}{*}{ LNA } & 1 & $5.98 *$ & $1.42^{\mathrm{ns}}$ & $10.39 * *$ & $8.75^{* *}$ & $13.29 * *$ & $2.97^{\mathrm{ns}}$ \\
\hline & 4 & $6.57 * *$ & $7.97^{\mathrm{ns}}$ & $13.84 *$ & $10.87^{\mathrm{ns}}$ & $4.33^{*}$ & $5.96^{\mathrm{ns}}$ \\
\hline \multirow[t]{2}{*}{ ALA } & 1 & $0.58^{\mathrm{ns}}$ & $0.21^{\mathrm{ns}}$ & $3.25^{\mathrm{ns}}$ & $4.75^{*}$ & $33.97 * * *$ & $0.01^{\mathrm{ns}}$ \\
\hline & 4 & $12.69 * * *$ & $6.69 * *$ & $5.13 *$ & $2.99^{\mathrm{ns}}$ & $12.17 * * *$ & $0.79^{\mathrm{ns}}$ \\
\hline
\end{tabular}

\begin{tabular}{lcl}
\hline \hline $\begin{array}{l}\text { Response } \\
\text { variable }\end{array}$ & df & $\begin{array}{l}\mathrm{F}_{\text {perennial }} \\
\text { ryegrass }\end{array}$ \\
$\begin{array}{l}\text { Development } \\
\text { (days to two- }\end{array}$ & 1 & $\begin{array}{l}39.29 * * * \\
\text { leaf phase) }\end{array}$ \\
& 1 & $9.33^{* *}$ \\
Wet mass & 1 & $0.32^{\text {ns }}$ \\
& 1 & $40.52^{* * *}$ \\
& & \\
Dry mass & 1 & $2.61^{\text {ns }}$ \\
& 1 & $41.39 * * *$ \\
\hline
\end{tabular}




\begin{tabular}{|c|c|c|}
\hline & df & $\begin{array}{c}\mathrm{F}_{\text {perennial }} \\
\text { ryegrass }\end{array}$ \\
\hline $\begin{array}{l}\text { Hotelling- } \\
\text { Lawley Trace }\end{array}$ & 16 & $1.22^{\mathrm{ns}}$ \\
\hline $\begin{array}{l}\text { Response } \\
\text { variable }\end{array}$ & $\overline{\mathrm{dff}}$ & $\begin{array}{l}\mathrm{F}_{\text {perennial }} \\
\text { ryegrass }\end{array}$ \\
\hline SFA & $\begin{array}{l}1 \\
1\end{array}$ & $\begin{array}{l}0.18^{\mathrm{ns}} \\
0.39^{\mathrm{ns}}\end{array}$ \\
\hline MUFA & $\begin{array}{l}1 \\
1\end{array}$ & $\begin{array}{l}0.12^{\mathrm{ns}} \\
0.05^{\mathrm{ns}}\end{array}$ \\
\hline PUFA & $\begin{array}{l}1 \\
1\end{array}$ & $\begin{array}{l}0.01^{\mathrm{ns}} \\
0.15^{\mathrm{ns}}\end{array}$ \\
\hline SFA/PUFA & $\begin{array}{l}1 \\
1\end{array}$ & $\begin{array}{l}8.66^{* *} \\
13.59 *\end{array}$ \\
\hline & $\overline{d f}$ & $\begin{array}{l}\mathrm{F}_{\text {perennial }} \\
\text { ryegrass }\end{array}$ \\
\hline $\begin{array}{l}\text { Hotelling- } \\
\text { Lawley Trace }\end{array}$ & 24 & $0.48^{*}$ \\
\hline
\end{tabular}




\begin{tabular}{|c|c|c|}
\hline $\begin{array}{l}\text { Response } \\
\text { variable }\end{array}$ & $\overline{\mathrm{df}}$ & $\begin{array}{l}\mathrm{F}_{\text {perennial }} \\
\text { ryegrass }\end{array}$ \\
\hline \multirow[t]{2}{*}{ SFA } & 1 & $2.01^{\mathrm{ns}}$ \\
\hline & 1 & $14.51 * * *$ \\
\hline \multirow[t]{2}{*}{ MUFA } & 1 & $0.59^{\mathrm{ns}}$ \\
\hline & 1 & $0.34^{\mathrm{ns}}$ \\
\hline \multirow[t]{2}{*}{ PUFA } & 1 & $2.10^{\mathrm{ns}}$ \\
\hline & 1 & $9.56 * *$ \\
\hline \multirow[t]{3}{*}{ SFA/PUFA } & 1 & $2.35^{\mathrm{ns}}$ \\
\hline & 1 & $13.89 * * *$ \\
\hline & $\mathrm{df}$ & $\begin{array}{l}\mathrm{F}_{\text {perennial }} \\
\text { ryegrass }\end{array}$ \\
\hline Hotelling- & 24 & $1.54^{\mathrm{ns}}$ \\
\hline Lawley Trace & & \\
\hline
\end{tabular}




\begin{tabular}{|c|c|c|}
\hline $\begin{array}{l}\text { Response } \\
\text { variable }\end{array}$ & $\mathrm{df}$ & 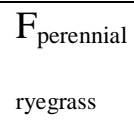 \\
\hline \multirow[t]{2}{*}{$15: 0$} & 1 & $3.29^{\mathrm{ns}}$ \\
\hline & 1 & $5.85^{*}$ \\
\hline \multirow[t]{2}{*}{$16: 0$} & 1 & $1.63^{\mathrm{ns}}$ \\
\hline & 1 & $2.94^{\mathrm{ns}}$ \\
\hline \multirow[t]{2}{*}{ 18:0 } & 1 & 2.46 \\
\hline & 1 & $7.14 *$ \\
\hline \multirow[t]{2}{*}{$18: 1 n-9 c$} & 1 & $2.08^{\mathrm{ns}}$ \\
\hline & 1 & $1.91^{\mathrm{ns}}$ \\
\hline \multirow[t]{2}{*}{ LNA } & 1 & $1.42^{\mathrm{ns}}$ \\
\hline & 1 & $2.71^{\mathrm{ns}}$ \\
\hline \multirow[t]{3}{*}{ ALA } & 1 & $8.26^{* *}$ \\
\hline & 1 & $0.44^{\mathrm{ns}}$ \\
\hline & $\overline{\mathrm{df}}$ & $\begin{array}{l}F_{\text {perennial }} \\
\text { ryegrass }\end{array}$ \\
\hline Hotelling- & 12 & $1.63^{\mathrm{ns}}$ \\
\hline Lawley Trace & & \\
\hline
\end{tabular}




\begin{tabular}{|c|c|c|}
\hline $\begin{array}{l}\text { Response } \\
\text { variable }\end{array}$ & $\mathrm{df}$ & $\begin{array}{l}\mathrm{F}_{\text {perennial }} \\
\text { ryegrass }\end{array}$ \\
\hline \multirow[t]{2}{*}{$15: 0$} & 1 & $0.43^{\mathrm{ns}}$ \\
\hline & 1 & $0.84^{\mathrm{ns}}$ \\
\hline \multirow[t]{2}{*}{$16: 0$} & 1 & $4.26^{*}$ \\
\hline & 1 & $7.83 * *$ \\
\hline \multirow[t]{2}{*}{ 18:0 } & 1 & $1.98^{\text {ns }}$ \\
\hline & 1 & $11.40 * *$ \\
\hline \multirow[t]{2}{*}{$18: 1 n-9 c$} & 1 & $10.41 * *$ \\
\hline & 1 & $15.55 * *$ \\
\hline \multirow[t]{2}{*}{ LNA } & 1 & $3.03^{\text {ns }}$ \\
\hline & 1 & $5.75^{\mathrm{ns}}$ \\
\hline \multirow[t]{2}{*}{ ALA } & 1 & $10.83 * *$ \\
\hline & 1 & $18.99 * *$ \\
\hline
\end{tabular}

Appendix 5.4: Summary of linear, quadratic, and cubic regression statistics for the relationship between temperature and absolute values ( $\mu \mathrm{g} / \mathrm{mgDW})$ of fatty acids of seven plant species. The $\mathrm{R}^{2}$ value refers to the fit of the overall regression model, $\beta 1$ to the linear regression coefficient, $\beta 2$ to the quadratic regression coefficient, and $\beta 3$ to the cubic regression coefficient: $\mathrm{ns}=\mathrm{P}>0.05 ; *=\mathrm{P}<0.05 ; * *=\mathrm{P}<$ $0.01 ; * * *=\mathrm{P}<0.001$. 


\begin{tabular}{|c|c|c|c|c|c|c|c|c|c|c|c|c|c|c|c|}
\hline \multirow[t]{2}{*}{ Species } & \multicolumn{3}{|c|}{ SFA } & \multirow[t]{2}{*}{$\mathbf{R}^{2}$} & \multirow[t]{2}{*}{ df } & \multicolumn{3}{|c|}{ MUFA } & \multirow[t]{2}{*}{$\mathbf{R}^{2}$} & \multirow[t]{2}{*}{ df } & \multicolumn{3}{|c|}{ PUFA } & \multirow[t]{2}{*}{$\mathbf{R}^{2}$} & \multirow[t]{2}{*}{ df } \\
\hline & $\beta_{1}$ & $\boldsymbol{\beta}_{2}$ & $\boldsymbol{\beta}_{3}$ & & & $\beta_{1}$ & $\boldsymbol{\beta}_{2}$ & $\boldsymbol{\beta}_{3}$ & & & $\beta_{1}$ & $\boldsymbol{\beta}_{2}$ & $\boldsymbol{\beta}_{3}$ & & \\
\hline Kentucky bluegrass & $-2.64 *$ & $2.69 *$ & $-2.72 *$ & & 3 & $-1.28^{\mathrm{ns}}$ & $1.24^{\mathrm{ns}}$ & $-1.20^{\mathrm{ns}}$ & & 3 & $0.72^{\mathrm{ns}}$ & $-0.53^{\mathrm{ns}}$ & --- & & 2 \\
\hline Orchardgrass & $-2.35 *$ & $2.40^{*}$ & $-2.45^{*}$ & & 3 & $-2.76 *$ & $2.80^{*}$ & $-2.83 *$ & & 3 & $-1.05^{\mathrm{ns}}$ & $1.10^{\mathrm{ns}}$ & $-1.13^{\mathrm{ns}}$ & & 3 \\
\hline Perennial ryegrass & $-1.10^{\mathrm{n}}$ & $1.19^{\mathrm{ns}}$ & $-1.30^{\mathrm{ns}}$ & & 3 & $-1.12^{\mathrm{ns}}$ & $1.18^{\mathrm{ns}}$ & $-1.25^{\mathrm{ns}}$ & & 3 & $-1.05^{\mathrm{ns}}$ & $1.14^{\mathrm{ns}}$ & $-1.05^{\mathrm{ns}}$ & & 3 \\
\hline White clover & $-0.79^{\mathrm{ns}}$ & $0.74^{\mathrm{ns}}$ & --- & & 2 & $-2.21 *$ & $2.17^{*}$ & $-2.14 *$ & & 3 & $-3.80 * *$ & $3.65^{* *}$ & $-3.49 * *$ & & 3 \\
\hline Tall fescue & $-2.28 *$ & $2.26^{*}$ & $-2.22 *$ & & 3 & $-1.80^{\mathrm{ns}}$ & $1.77^{\mathrm{ns}}$ & $-1.71^{\mathrm{ns}}$ & & 3 & $1.66^{\mathrm{ns}}$ & $1.61^{\mathrm{ns}}$ & $-1.54^{\mathrm{ns}}$ & & 3 \\
\hline Alfalfa & $1.31^{\mathrm{ns}}$ & $-1.35^{\mathrm{ns}}$ & $1.38^{\mathrm{ns}}$ & & 3 & $-0.46^{\mathrm{ns}}$ & $0.40^{\mathrm{ns}}$ & --- & & 2 & $1.80^{\mathrm{ns}}$ & $-1.80^{\mathrm{ns}}$ & $1.82^{\mathrm{ns}}$ & & 3 \\
\hline Smooth bromegrass & $-0.94^{\mathrm{ns}}$ & $0.88^{\mathrm{ns}}$ & --- & & 2 & $0.48^{\mathrm{ns}}$ & $-0.42^{\mathrm{ns}}$ & $0.35^{\mathrm{ns}}$ & & 3 & $0.52^{\mathrm{ns}}$ & $-0.57^{\mathrm{ns}}$ & --- & & 2 \\
\hline
\end{tabular}




\begin{tabular}{|c|c|c|c|c|c|}
\hline \multirow[t]{2}{*}{ Species } & \multicolumn{3}{|c|}{ SFA/PUFA } & \multirow[t]{2}{*}{$\mathbf{R}^{2}$} & \multirow[t]{2}{*}{ df } \\
\hline & $\beta_{1}$ & $\boldsymbol{\beta}_{2}$ & $\boldsymbol{\beta}_{3}$ & & \\
\hline Kentucky bluegrass & $-4.51 * * *$ & $4.60 * * *$ & $-4.70 * * *$ & & 3 \\
\hline Orchardgrass & $-1.83^{\mathrm{ns}}$ & --- & --- & & 1 \\
\hline Perennial ryegrass & $-3.12 * *$ & --- & --- & & 1 \\
\hline White clover & $-1.30^{\mathrm{ns}}$ & $1.32^{\mathrm{ns}}$ & $-1.35^{\mathrm{ns}}$ & & 3 \\
\hline Tall fescue & $2.22 *$ & $-2.13^{*}$ & --- & & 2 \\
\hline Alfalfa & $-2.34 *$ & $2.31^{*}$ & $-2.28 *$ & & 3 \\
\hline Smooth bromegrass & $-1.09^{\mathrm{ns}}$ & $1.20^{\mathrm{ns}}$ & $-1.31^{\mathrm{ns}}$ & & 2 \\
\hline
\end{tabular}



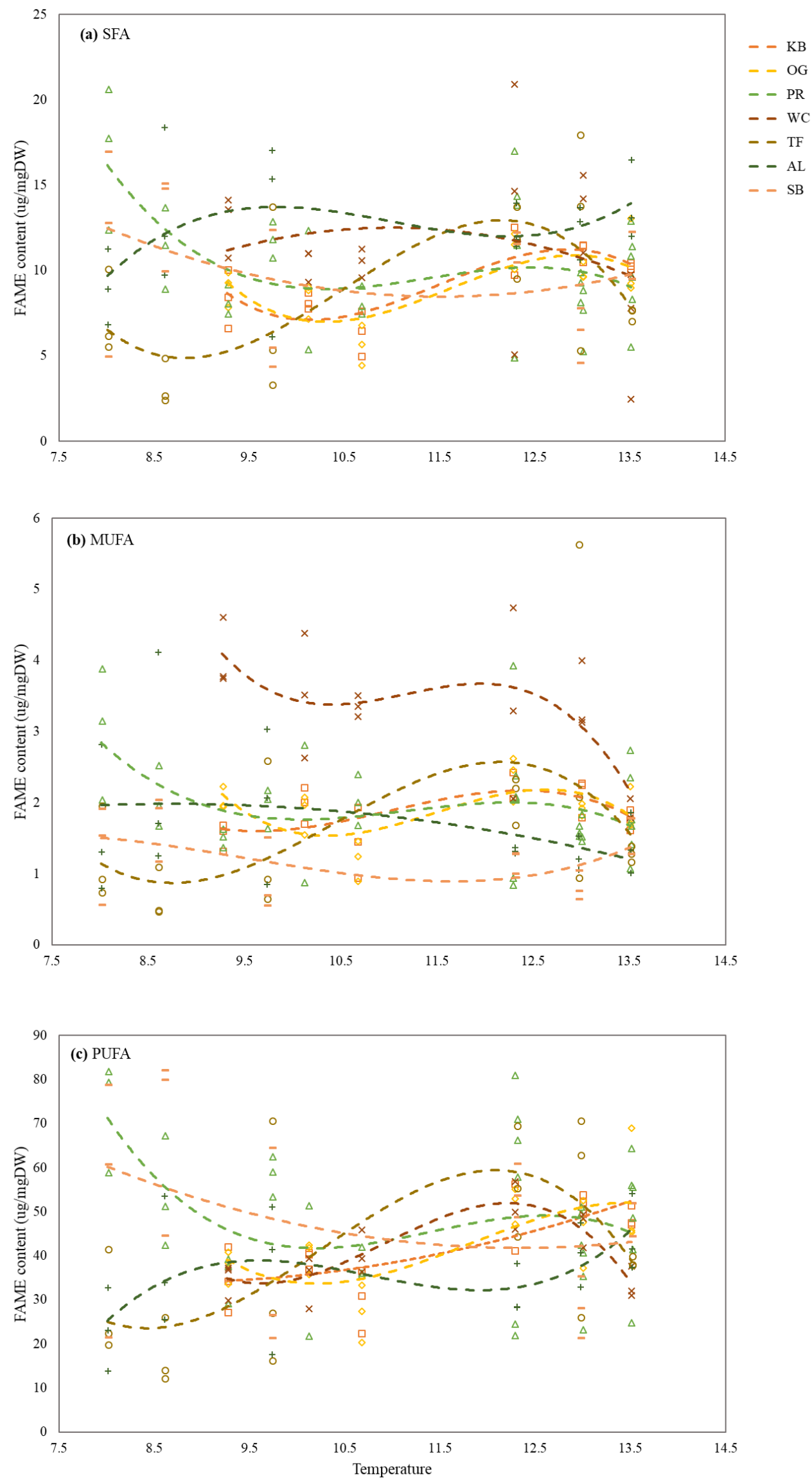


\begin{tabular}{|c|c|c|c|c|c|c|c|c|c|c|c|c|c|c|c|}
\hline \multirow[t]{2}{*}{ Species } & \multicolumn{3}{|c|}{$15: 0$} & \multirow[t]{2}{*}{$\mathbf{R}^{2}$} & \multirow[t]{2}{*}{ df } & \multicolumn{3}{|c|}{ 16:0 } & \multirow[t]{2}{*}{$\mathbf{R}^{2}$} & \multirow[t]{2}{*}{ dff } & \multicolumn{3}{|c|}{ 18:0 } & \multirow[t]{2}{*}{$\overline{\mathbf{R}^{2}}$} & \multirow[t]{2}{*}{$\overline{d \mathrm{~d}}$} \\
\hline & $\beta_{1}$ & $\boldsymbol{\beta}_{2}$ & $\boldsymbol{\beta}_{3}$ & & & $\beta_{1}$ & $\boldsymbol{\beta}_{2}$ & $\boldsymbol{\beta}_{3}$ & & & $\beta_{1}$ & $\boldsymbol{\beta}_{2}$ & $\boldsymbol{\beta}_{3}$ & & \\
\hline Kentucky bluegrass & $-1.79^{\mathrm{ns}}$ & $1.82^{\mathrm{ns}}$ & $-1.83^{\mathrm{ns}}$ & & 3 & $-2.33 *$ & $2.37 *$ & $-2.40 *$ & & 3 & $-4.01 * *$ & $4.06^{* *}$ & $-4.09 * *$ & & 3 \\
\hline Orchardgrass & $-2.55^{*}$ & $2.59 *$ & $-2.62^{*}$ & & 3 & $-1.50^{\mathrm{ns}}$ & $1.57^{\mathrm{ns}}$ & $-1.62^{\mathrm{ns}}$ & & 3 & $-3.42 * *$ & $3.45^{* *}$ & $-3.48 * * *$ & & 3 \\
\hline Perennial ryegrass & $-0.75^{\mathrm{ns}}$ & $0.78^{\text {ns }}$ & $-0.82^{\mathrm{ns}}$ & & 3 & $-1.67^{\mathrm{ns}}$ & --- & --- & & 1 & $-2.18 *$ & --- & --- & & 1 \\
\hline Tall fescue & $-2.96^{*}$ & $2.88^{*}$ & $-2.77^{*}$ & & 3 & $-1.95^{\mathrm{ns}}$ & $1.92^{\mathrm{ns}}$ & $-1.86^{\mathrm{ns}}$ & & 3 & $-2.32 *$ & $2.30 *$ & $-2.27 *$ & & 3 \\
\hline Alfalfa & $1.26^{\mathrm{ns}}$ & $-1.37^{\mathrm{ns}}$ & $1.48^{\mathrm{ns}}$ & & 3 & $1.75^{\mathrm{ns}}$ & $-1.79^{\mathrm{ns}}$ & $1.82^{\mathrm{ns}}$ & & 3 & $-0.94^{\mathrm{ns}}$ & $0.97^{\mathrm{ns}}$ & $-1.00^{\mathrm{ns}}$ & & 3 \\
\hline Smooth bromegrass & $-1.46^{\mathrm{ns}}$ & $1.45^{\mathrm{ns}}$ & $-1.44^{\mathrm{ns}}$ & & 3 & $0.91^{\mathrm{ns}}$ & $-0.95^{\mathrm{ns}}$ & --- & & 2 & $-0.35^{\mathrm{ns}}$ & $0.43^{\text {ns }}$ & $-0.52^{\mathrm{ns}}$ & & 3 \\
\hline Species & \multicolumn{3}{|c|}{ 18:1n-9c } & $\mathbf{R}^{2}$ & df & & ALA & & $\overline{\mathbf{R}^{2}}$ & dff & \multicolumn{3}{|c|}{ LNA } & $\mathbf{R}^{2}$ & df \\
\hline Kentucky bluegrass & $-1.96^{\mathrm{ns}}$ & $1.95^{\mathrm{ns}}$ & $-1.93^{\mathrm{ns}}$ & & 3 & $-1.04^{\mathrm{ns}}$ & $1.07^{\mathrm{ns}}$ & $-1.08^{\mathrm{ns}}$ & & 3 & $-2.40^{*}$ & $2.42 *$ & $-2.42 *$ & & 3 \\
\hline Orchardgrass & $-0.89^{\mathrm{ns}}$ & $0.91^{\mathrm{ns}}$ & $-0.94^{\mathrm{ns}}$ & & 3 & $-0.69^{\mathrm{ns}}$ & $0.74^{\mathrm{ns}}$ & $-0.79^{\mathrm{ns}}$ & & 3 & $-1.88^{\mathrm{ns}}$ & $1.90^{\mathrm{ns}}$ & $-1.91^{\mathrm{ns}}$ & & 3 \\
\hline Perennial ryegrass & $-1.51^{\mathrm{ns}}$ & --- & --- & & 1 & $-1.72^{\mathrm{ns}}$ & $1.82^{\mathrm{ns}}$ & $-1.04^{\mathrm{ns}}$ & & 3 & $-1.44^{\mathrm{ns}}$ & --- & --- & & 1 \\
\hline White clover & $-0.64^{\mathrm{ns}}$ & $0.52^{\mathrm{ns}}$ & --- & & 2 & $-2.62 *$ & $2.44 *$ & $-2.26^{*}$ & & 3 & $-1.38^{\mathrm{ns}}$ & $1.44^{\mathrm{ns}}$ & --- & & 2 \\
\hline Tall fescue & $-1.76^{\mathrm{ns}}$ & $1.71^{\mathrm{ns}}$ & $-1.64^{\mathrm{ns}}$ & & 3 & $-1.58^{\mathrm{ns}}$ & $1.53^{\mathrm{ns}}$ & $-1.46^{\mathrm{ns}}$ & & 3 & $-1.95^{\mathrm{ns}}$ & $1.90^{\mathrm{ns}}$ & $-1.82^{\mathrm{ns}}$ & & 3 \\
\hline Alfalfa & $1.24^{\mathrm{ns}}$ & $-1.36^{\mathrm{ns}}$ & $1.50^{\mathrm{ns}}$ & & 3 & $1.96^{\mathrm{ns}}$ & $-1.97^{\mathrm{ns}}$ & $1.97^{\mathrm{ns}}$ & & 3 & $-1.41^{\mathrm{ns}}$ & $1.35^{\mathrm{ns}}$ & $-1.29^{\mathrm{ns}}$ & & 3 \\
\hline Smooth bromegrass & $1.03^{\mathrm{ns}}$ & $-0.98^{\mathrm{ns}}$ & $0.92^{\text {ns }}$ & & 3 & $-0.47^{\mathrm{ns}}$ & $-0.49^{\mathrm{ns}}$ & $-0.50^{\mathrm{ns}}$ & & 3 & $0.13^{\mathrm{ns}}$ & $-0.10^{\mathrm{ns}}$ & $0.06^{\mathrm{ns}}$ & & 3 \\
\hline
\end{tabular}



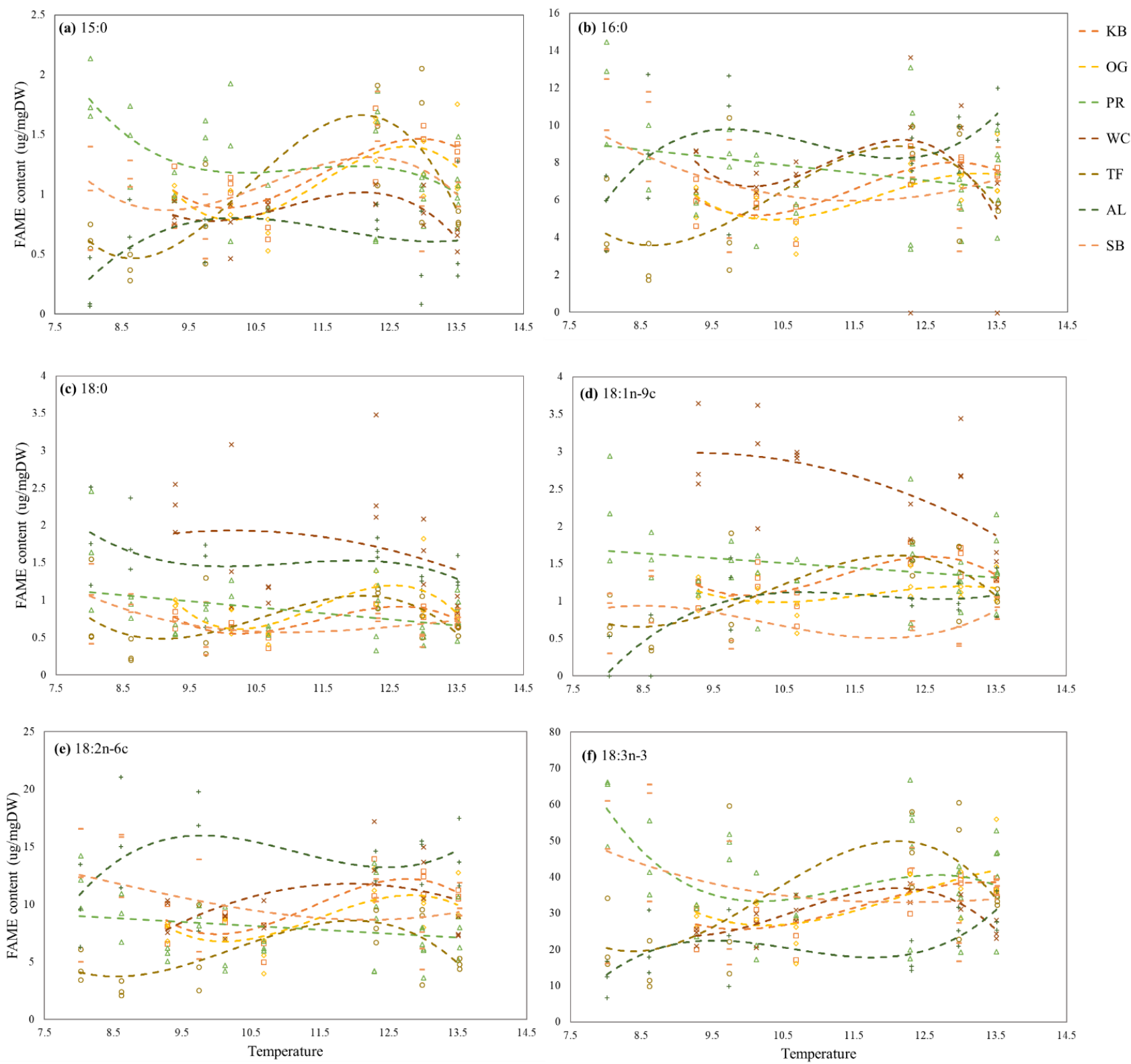


\begin{tabular}{|c|c|c|c|c|c|}
\hline \multirow[t]{2}{*}{ Species } & \multicolumn{3}{|c|}{$\overline{\mathbf{U I}}$} & \multirow[t]{2}{*}{$\begin{array}{l}\mathbf{R}^{2} \\
\end{array}$} & \multirow[t]{2}{*}{$\overline{\text { df }}$} \\
\hline & $\beta_{1}$ & $\boldsymbol{\beta}_{2}$ & $\beta_{3}$ & & \\
\hline Kentucky bluegrass & $0.71^{\mathrm{ns}}$ & $-0.53^{\text {ns }}$ & --- & & 2 \\
\hline Orchardgrass & $-1.02^{\mathrm{ns}}$ & $1.07^{\mathrm{ns}}$ & $-1.10^{\mathrm{ns}}$ & & 3 \\
\hline Perennial ryegrass & $-1.38^{\mathrm{ns}}$ & $1.42^{\mathrm{ns}}$ & $-1.46^{\mathrm{ns}}$ & & 3 \\
\hline White clover & $-4.12 * *$ & $3.96^{* *}$ & -3.78 & & 3 \\
\hline Tall fescue & $-1.60^{\mathrm{ns}}$ & $1.53^{\mathrm{ns}}$ & $-1.44^{\mathrm{ns}}$ & & 3 \\
\hline Alfalfa & $1.82^{\mathrm{ns}}$ & $-1.82^{\mathrm{ns}}$ & $1.83^{\mathrm{ns}}$ & & 3 \\
\hline Smooth bromegrass & $-0.26^{\mathrm{ns}}$ & $0.27^{\mathrm{ns}}$ & $-0.30^{\mathrm{ns}}$ & & 3 \\
\hline
\end{tabular}

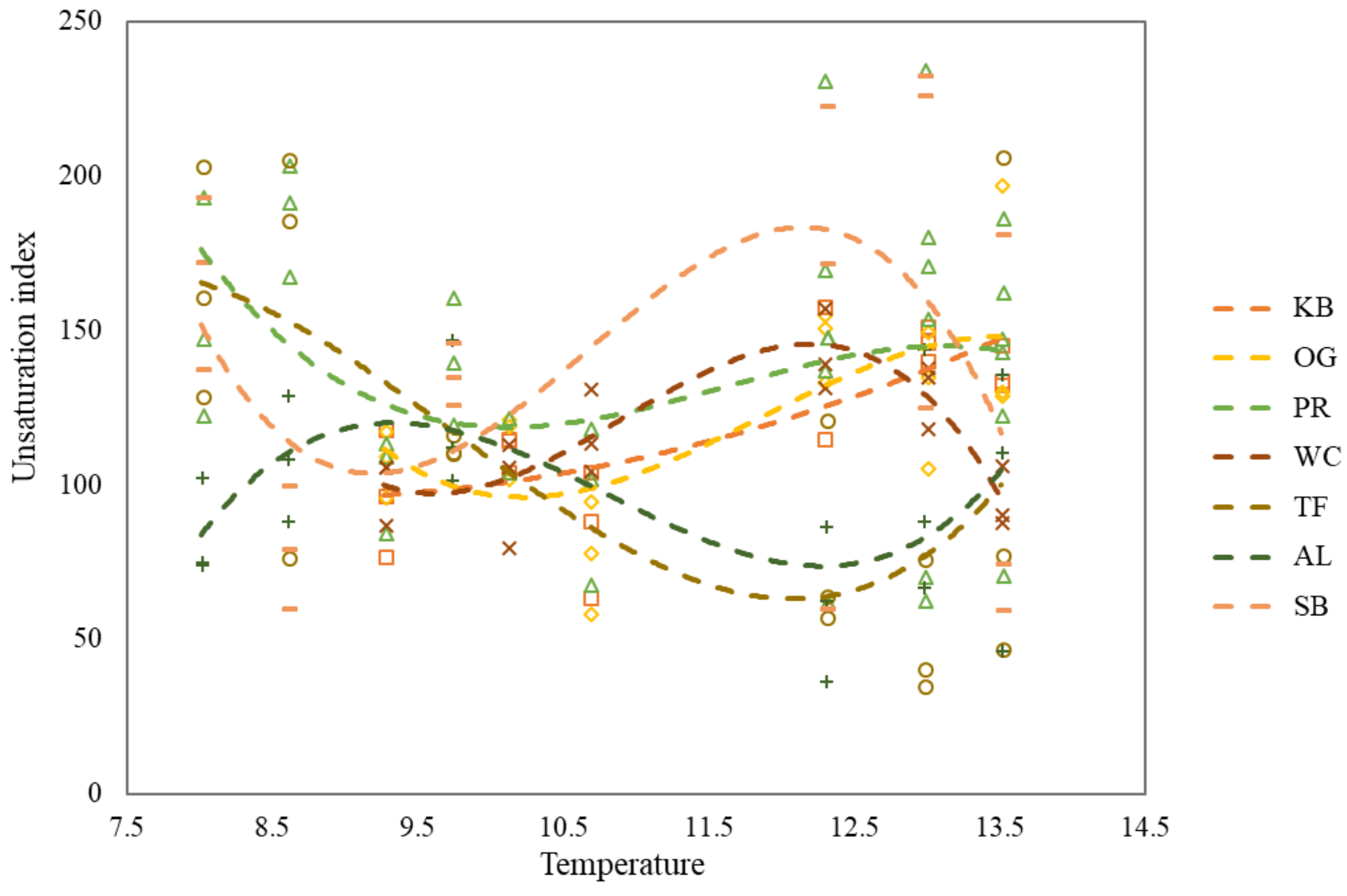


Appendix 5.5: Average ALA content (\% by dry weight \pm SD) of the seven observed species, Poaceae (24) and Fabaceae (59).

\begin{tabular}{cc}
\hline \hline Plant group & Average ALA content $( \pm$ SD $)$ \\
\hline Species in this study & $59.70 \pm 8.63$ \\
Poaceae & $5.03 \pm 4.19$ \\
Fabaceae & $12.84 \pm 16.73$ \\
\hline
\end{tabular}

Appendix 5.6: Average LNA and ALA content $(\mu \mathrm{g} / \mathrm{mgDW} \pm \mathrm{SD})$ of the seven species observed in these trials.

\begin{tabular}{ccc}
\hline \hline Species & \multicolumn{2}{c}{ Average content $(\boldsymbol{\mu g} / \mathbf{m g D W})$} \\
& LNA & ALA \\
\hline Kentucky bluegrass & $9.73 \pm 2.39$ & $31.85 \pm 7.34$ \\
Orchardgrass & $8.87 \pm 2.34$ & $33.47 \pm 8.84$ \\
Perennial ryegrass & $7.95 \pm 2.75$ & $39.88 \pm 14.18$ \\
White clover & $10.31 \pm 2.88$ & $29.39 \pm 5.34$ \\
Tall fescue & $5.56 \pm 2.68$ & $32.76 \pm 17.03$ \\
Alfalfa & $13.71 \pm 3.82$ & $21.31 \pm 8.37$ \\
Smooth bromegrass & $10.25 \pm 3.93$ & $37.97 \pm 16.15$ \\
\hline
\end{tabular}


Appendix 5.7: Average LNA and ALA content per acre (kg) as a function of temperature in a) orchardgrass, perennial ryegrass, tall fescue, and smooth bromegrass, b) white clover and alfalfa, and c) Kentucky bluegrass; values were calculated based on OMAFRA (2015) seeding density recommendations for each species (each group had similar recommended seeding densities) and average dry weight (mg) per plant.
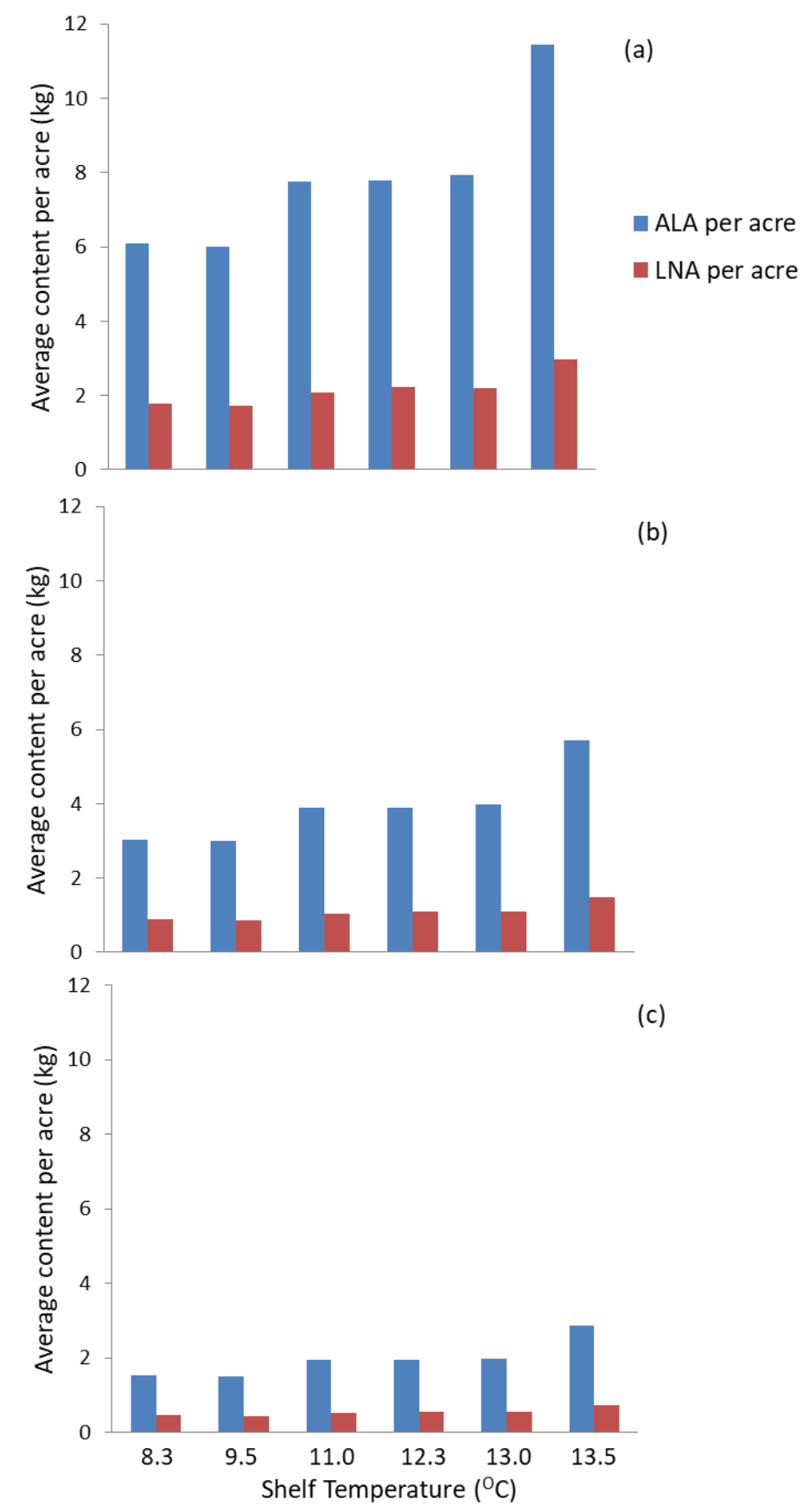
Appendix 5.8: Average fatty acid content (\% FAME $\pm 95 \% \mathrm{CI}$ ) of five common FA in plants from north temperate, north tropical, south temperate, and south tropical latitudes.

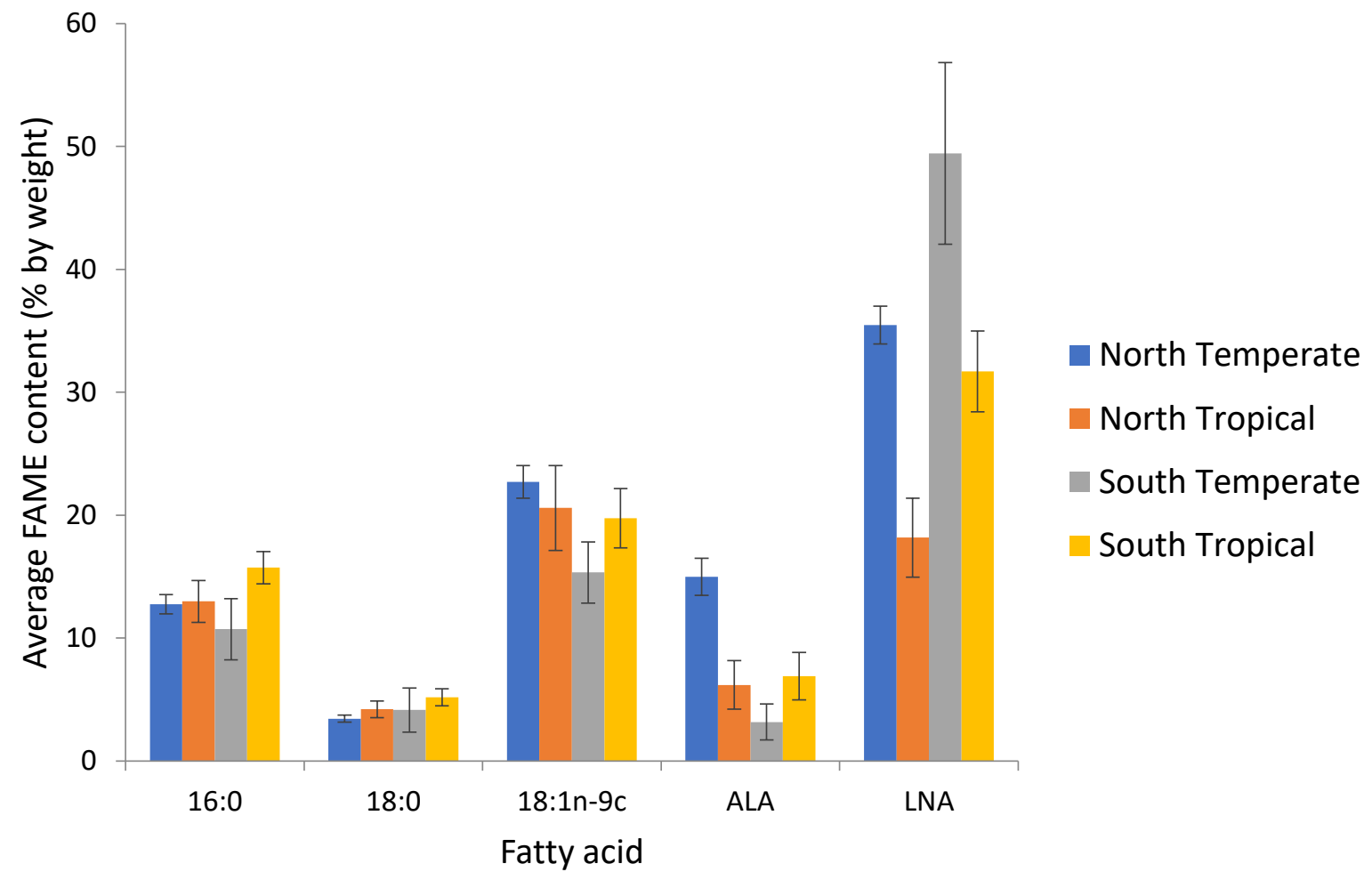




\section{References}

Addis M, Cabiddu A, Pinna G, Decandia M, Piredda G, Pirisi A, Molle G. 2005. Milk and cheese fatty acid composition in sheep fed Mediterranean forages with reference to conjugated linoleic acid cis9, trans-11. Journal of Dairy Science 88: 3443-3454.

Amminger GP, Schafer MR, Klier CM, Slavik JM, Holzer I, Holub M, Goldstone S. 2012. Decreased nervonic acid levels in erythrocyte membranes predict psychosis in help-seeking ultra-high-risk individuals. Molecular Psychiatry 17: 1150-1152.

Arts MT, Ackman RG, Holub BJ. 2001. "Essential fatty acids" in aquatic ecosystems: A crucial link between diet and human health and evolution. Canadian Journal of Fisheries and Aquatic Sciences 58: 122-137.

Arts MT, Kohler CC. 2009. Health and condition in fish: the influence of lipids on membrane competency and immune response. In: Kainz M., Brett M., Arts M. (eds) Lipids in Aquatic Ecosystems. Springer, New York, NY, 237-255.

Bao X, Ohlrogge J. 1999. Supply of fatty acid is one limiting factor in the accumulation of triacylglycerol in developing embryos. Plant Physiology 120: 1057-1062.

Barceló-Coblijn G, Murphy EJ. 2009. Alpha-linolenic acid and its conversion to longer chain n-3 fatty acids: Benefits for human health and a role in maintaining tissue n-3 fatty acid levels. Progress in Lipid Research 48: 355-374.

Barros L, Carvalho AM, Ferreira ICFR. 2010 The nutritional composition of fennel (Foeniculum vulgare): Shoots, leaves, stems and inflorescences. Food Science and Technolology 43: 814-818.

Baydar, H. 2005. Breeding for the improvement of the ideal plant type of sesame. Plant Breeding 124: 263-267.

Bazinet RP, Laye S. 2014. Polyunsaturated fatty acids and their metabolites in brain function and disease. Nature Reviews Neuroscience 15: 771-785.

Bazinet RP, McMillan EG, Cunnane SC. 2003. Dietary $\alpha$-linolenic acid increases the n-3 PUFA content of sow's milk and the tissues of the suckling piglet. Lipids 38: 6-10. 
Bazzaz FA, Sombroek WG, editors. 1996. Global climate change and agricultural production: direct and indirect effects of changing hydrological, pedological and plant physiological processes. Food \& Agriculture Org.

Beck JG, Mathieu D, Dufourc EJ, Beck JG, Plant JD. 2017. Plant sterols in 'rafts': A better way to regulate membrane thermal shocks. Federation of American Societies for Experimental Biology 21: 1714-1723.

Behrouzian B, Buist PH. 2003. Mechanism of fatty acid desaturation: A bioorganic perspective. Prostaglandins, Leukotrienes and Essential Fatty Acids 68: 107-112.

Berry JA, Bjorkman O. 1980. Photosynthetic response and adaptation to temperature in higher plants. Annual Reviews in Plant Physiology 31: 491-543.

Berry JA. 2015. Photosynthetic response and adaptation to temperature in higher plants. Annual Review of Plant Physiology 31: 491-543.

Beschta RL, Bilby RE, Brown GW, Holtby LB, Hofstra TD. 1987. CHAPTER SIX Stream Temperature and Aquatic Habitat: Fisheries and Forestry Interactions.

Birch EE, Carlson SE, Hoffman DR, Fitzgerald-Gustafson KM, Fu VLN, Drover JR, Castaneda YS, Minns L, Wheaton DKH, Mundy D. et al. 2010. The DIAMOND (DHA Intake And Measurement Of Neural Development) Study: A double-masked, randomized controlled clinical trial of the maturation of infant visual acuity as a function of the dietary level of docosahexaenoic acid. American Journal of Clinical Nutrition 91: 848-859.

Blondeau N, Lipsky RH, Bourourou M, Duncan MW, Gorelick PB, Marini AM. 2015. Alpha-linolenic acid: An omega-3 fatty acid with neuroprotective properties - Ready for use in the stroke clinic? Biomed Research International 2015: 1-8.

Bogucka-Kocka A, Janyszek M. 2010. Fatty acids composition of fruits of selected Central European sedges (Carex L. Cyperaceae). Grasas y Aceites 61: 165-170.

Bonaventure G, Salas JJ, Pollard MR, Ohlrogge JB. 2003. Disruption of the FATB gene in Arabidopsis demonstrates an essential role of saturated fatty acids in plant growth. Plant Cell 15: 1020-1033. 
Bonnefield Research. 2016. Canada's forage crop: The overlooked cornerstone of Canadian Agriculture. Ottawa, ON, Canada.

Borges RM. 2009. Phenotypic plasticity and longevity in plants and animals: cause and effect? Journal of Bioscience 34: 605-611.

Boyes DC, Zayed AM, Ascenzi R, McCaskill AJ, Hoffman NE, Davis KR, Gorlach J. 2001. Growth stage-based phenotypic analysis of Arabidopsis: A model for high throughput functional genomics in plants. The Plant Cell 13: 1499-1510.

Brenna JT, Salem N, Sinclair AJ, Cunnane SC. 2009. $\alpha$-Linolenic acid supplementation and conversion to n-3 long-chain polyunsaturated fatty acids in humans. Prostaglandins, Leukotrienes and Essential Fatty Acids 80: 85-91.

Brett MT, Muller-Navarra C. 1997. The role of highly unsaturated fatty acids in aquatic food web processes. Freshwater Biology 38: 483-499.

Brough CL, Coventry JM, Christie WW, Kroon JTM, Brown AP, Barsby TL, Slabas AR. 1996. Towards the genetic engineering of triacylglycerols of defined fatty acid composition: Major changes in erucic acid content at the sn-2 position affected by the introduction of a I-acyl-sn-glycerol-3phosphate acyltransferase from Limnanthes douglasii into oil seed rape. Molecular Breeding 2: $133-142$.

Broun P, Shanklin J, Whittle E, Somerville C. 1998. Catalytic plasticity of fatty acid modification enzymes underlying chemical diversity of plant lipids. Science 282: 1315-1317.

Browse J, Roughan PG, Slack CR. 1981. Light control of fatty acid synthesis and diurnal fluctuations of fatty acid composition in leaves. Biochemical Journal 1: 347-354.

Bunger, M., Staff, R., \& Barickman, G. 2012. Grazing factsheets - species - cool-season grasses | NRCS Illinois. Retrieved from https://www.nrcs.usda.gov/wps/portal/nrcs/detail/i1/technical/landuse/pasture/?cid=nrcs141p2 030 $\underline{606}$

Burdge GC, Calder PC. Dietary $\alpha$-linolenic acid and health-related outcomes: A metabolic perspective. Nutrition Research Reviews 19: 26-52. 
Burr GO, Burr MM. 1929. A new deficiency disease produced by the rigid exclusion of fat from the diet. Journal of Biological Chemistry 82: 345-367.

Burr GO, Burr MM. 1930. On the nature and role of the fatty acids essential in nutrition. Journal of Biological Chemistry 82: 345-367.

Campos ML, Kang J-H, Howe GA. 2014. Jasmonate-triggered plant immunity. Journal of Chemical Ecology 40: 657-675.

Canvin DT. 1964. The effect of temperature on the oil content and fatty acid composition of the oils from several oil seed crops. Canadian Journal of Botany 43: 63-69.

Capella P, Zorzut CM. 1967. Determination of double bond position in monounsaturated fatty acid esters by mass spectrometry of their trimethylsilyloxy derivatives. Analytical Chemistry 1302: 14581463.

Carroll AB, Pallardy SG, Galen C. 2001. American Journal of Botany 88: 438-446.

Chapin FS, Torn MS, Tateno M. 1996. Principles of ecosystem sustainability. The American Naturalist 148: 1016-1037.

Chapman DF, Clark DA, Land CA, Dymock N. 1983. Leaf and tiller growth of Lolium perenne and Agrostis spp . and leaf appearance rates of Trifolium repens in set-stocked and rotationally grazed hill pastures. New Zealand Journal of Agricultural Research. 26: 159-168.

Cheesbrough TM. 1989. Changes in the enzymes for fatty acid synthesis and desaturation during acclimation of developing soybean seeds to altered growth temperature. Plant Physiology 90: 760764.

Chen Y, Chiu H, Su Y, Wu Y, Cheng K. 2017. Does urbanization increase diurnal land surface temperature variation? Evidence and implications. Landscaping and Urban Planning 157: $247-$ 258.

Cherfaoui M, Durand D, Bonnet M, Bernard L, Bauchart D, Ortigues-Marty I, Gruffat D. 2013. A grassbased diet favours muscle n-3 long-chain PUFA deposition without modifying gene expression of proteins involved in their synthesis or uptake in Charolais steers. Animal 7: 1833-1840. 
Chilliard Y, Glasser F, Ferlay A, Bernard L, Rouel J, Doreau M. 2007. Diet, rumen biohydrogenation and nutritional quality of cow and goat milk fat. European Journal of Lipid Science and Technology 109: 828-855.

Clapham WM, Foster JG, Neel JPS, Fedders JM. 2005. Fatty acid composition of traditional and novel forages. Agricultural and Food Chemistry 53: 10068-10073.

Cleland EE, Chiariello NR, Loarie SR, Mooney HA, Field CB. 2006. Diverse responses of phenology to global changes in a grassland ecosystem. Proceedings of the National Academy of Sciences of the United States of America 103: 13740-13744.

Conant RT, Paustian K, Elliott ET. 2001. Grassland management and conversion into grassland: Effects on soil carbon. Ecological Applications 11: 343-355.

Correa SM, Athehortua L. 2012. Lipid profile of in vitro oil produced through cell culture of Jatropha curcas. Journal of AOAC International 94: 1161-1169.

Cross HR, Berry BW, Wells LH. 1980. Effects of fat level and source on the chemical, sensory and cooking properties of ground beef patties. Journal of Food Science 45: 791-793.

Daley CA, Abbott A, Doyle PS, Nader GA, Larson S. 2010. A review of fatty acid profiles and antioxidant content in grass-fed and grain-fed beef. Nutrition Journal 9: 1-12.

Davies PJ. 2004. Plant hormones: Biosynthesis, signal transduction, action! Kluwer Academic Publishers. Norwell, MA, USA.

Deineka VI, Gabruk NG, Deineka LA, Manokhina LA. 2002. Triglyceride composition of oil from stones of nine Rosaceae plants. Chemistry of Natural Compounds 38: 410-412.

Dembitsky VM, Rezanka T. 1995. Distribution of diacylglycerylhomoserines, phospholipids and fatty acids in thirteen moss species from Southwestern Siberia. Biochemical Systematics and Ecology 23: 71-78.

Dickinson Research Extension Center. 2000. Manske LL. Defoliation applied at some phenological growth stages negatively affects grass plants. Dickinson, ND, USA. 
Dolde D, Vlahakis C, Hazebroek J. 1999. Tocopherols in breeding lines and effects of planting location, fatty acid composition, and temperature during development. Journal of the American Oil Chemistry Society 76: 349-355.

Domenichiello AF, Kitson AP, Bazinet RP. 2015. Is docosahexaenoic acid synthesis from $\alpha$-linolenic acid sufficient to supply the adult brain? Progress in Lipid Research 59: 54-66.

Duncan DA, Woodmansee RG. 1975. Forecasting forage yield from precipitation in California's annual rangeland. Journal of Range Management 1: 327-329.

Dutta PC, Appelqvist L. 1991. Lipids and fatty acid patterns in developing seed, leaf, root, and in tissue culture initiated from embryos of Daucus carota L. Plant Science 75: 177-183.

Eagles CF. 1983. Relationship between competitive ability and yielding ability in mixtures and monocultures of populations of Dactylis glomerata L. Grass and Forage Science 38: 21-24.

Elgersma A, Ellen G, van der Horst H, Muuse BG, Boer H, Tamminga S. 2003. Influence of cultivar and cutting date on the fatty acid composition of perennial ryegrass (Lolium perenne L.). Grass and Forage Science 58: 323-331.

Elgersma A, Maudet P, Witkowska IM, Wever AC. 2005. Effects of nitrogen fertilisation and regrowth period on fatty acid concentrations in perennial ryegrass (Lolium perenne L.). 147: 145-152.

Elser JJ, Fagan WF, Denno RF, Dobberfuhl DR, Folarin A, Huberty A, Interland S, Killham SS, McCauley E, Schulz KL et al. 2000. Nutritional constraints in terrestrial and freshwater food webs. Nature 408: 578-580.

Endo J, Arita M. 2016. Cardioprotective mechanism of omega-3 polyunsaturated fatty acids. Journal of Cardiology 67: 22-27.

Enser M, Hallett KG, Hewett B, Fursey GAJ, Wood JD, Harrington G. 1998. Fatty acid content and composition of UK beef and lamb muscle in relation to production system and implications for human nutrition. Meat Science 49: 329-341.

Environment and Climate Change Canada. 2016. Climate Data and Scenarios for Canada: Synthesis of Recent Observation and Modelling Results. Gatineau, QC, Canada. Retrieved from http://climatescenarios.canada.ca/files/Climate\%20data\%20and\%20scenarios\%20for\%20Canada_EN_2016.pdf 
Environment and Natural Resources Canada. 2018. Weather, climate and hazards - Canada.ca. Retrieved from https://www.canada.ca/en/services/environment/weather.html

Ernst R, Ejsing CS, Antonny B. 2016. Homeoviscous adaptation and the regulation of membrane lipids. Journal of Molecular Biology 428: 4776-4791.

Falcone DL, Ogas JP, Somerville C.R. 2004. Regulation of membrane fatty acid composition by temperature in composition. BMC Plant Biology 15: 1-15.

Feller SE, Gawrisch K, Mackerell AD. 2002. Polyunsaturated fatty acids in lipid bilayers: Intrinsic and environmental contributions to their unique physical properties. Journal of the American Chemical Society 124: 318-326.

Ferguson A, Mallory FB, Davis M, Conner L, Landrey R. 1975. Effect of sterol replacement in vivo on the fatty acid composition of Tetrahymena. The Journal of Biological Chemistry 250: 6998-7005.

Flagella Z, Rotunno T, Tarantino E, Caterina R, Caro A. 2002. Changes in seed yield and oil fatty acid composition of high oleic sunflower (Helianthus annuus L.) hybrids in relation to the sowing date and the water regime. European Journal of Agronomy 17: 221-230.

Floris R, Dekker R, Slangen C, Ellen G. 2006. Influence of pasture feeding and stall feeding on CLA and other fatty acids in bovine milkfat. Australian Journal of Dairy Technology 61: 13-20.

Folch J, Lees, M, Stanley GHS. 1957. A simple method for the isolation and purification of total lipids from animal tissues. Journal of Biology and Chemistry 226: 497-509.

Franks SJ, Weber JJ, Aitken SN. 2013. Evolutionary and plastic responses to climate change in terrestrial plant populations. Evolutionary Applications 7: 123-139.

Freije A, Alkhuzai J, Al-Laith AA. 2013. Fatty acid composition of three medicinal plants from Bahrain: New potential sources of $\gamma$-linolenic acid and dihomo- $\gamma$-linolenic. Industrial Crops and Products 43: 218-224.

Garces R, Sarmiento C, Mancha M. 1992. Temperature regulation of oleate desaturase in sunflower (Helianthus annuus L.) seeds. Planta 186: 461-465. 
Glasser F, Ferlay A, Doreau M, Schmidely P, Sauvant D, Chilliard Y. 2008. Long-chain fatty acid metabolism in dairy cows: A meta-analysis of milk fatty acid yield in relation to duodenal flows and de novo synthesis. Journal of Dairy Science 91: 2771-2785.

Goossen CP, Kraft J, Bosworth SC. 2018. Fatty acids decrease in pearl millet forage from relative increases of pseudostem. Agricultural and Environmental Letters 1-4.

Gül MK, Egesel CÖ, Turhan H. 2008. The effects of planting time on fatty acids and tocopherols in chickpea. European Food Research and Technology 226: 517-522.

Gustavsson AM. 2011. A developmental scale for perennial forage grasses based on the decimal code framework. Grass Forage Science 66: 93-108.

Gwin L. 2009. Scaling-up sustainable livestock production: Innovation and challenges for grass-fed beef in the U.S. Journal of Sustainable Agriculture 33: 189-209.

Hall JM, Parrish CC, Thompson RJ. 2002. Eicosapentaenoic acid regulates scallop (Placopecten magellanicus) membrane fluidity in response to cold. Biological Bulletin 202: 201-203.

Harris BP, James AT. 1969a. The effect of low temperatures on fatty acid biosynthesis in Plants Biochemical Journal 112: 325-330.

Harris BP, James AT. 1969b. Effect in seeds of low temperature on fatty acid. Biochimica et Biophysica Acta 187: 13-18.

Hassan FU, Kaleem S, Ahmad M. 2011. Oil and fatty acid distribution in different circles of sunflower head. Food Chemistry 128: 590-595.

Hatfield JL, Prueger JH. 2015. Temperature extremes: Effect on plant growth and development. Weather and Climate Extremes 10: 4-10.

Heppard EP, Kinney AJ, Stecca KL, Miao GH. 1996. Developmental and growth temperature regulation of two different microsomal n-6 desaturase genes in soybeans. 110: 311-319.

Hellgren LI, Sandelius AS. 2001. Age-dependent variation in membrane lipid synthesis in leaves of garden pea (Pisum sativum L.). Journal of Experimental Botany 52: 2275-2282. 
Hendrickson M, Heffernan W. 2004. Lessons for public breeding from structural changes in the agricultural marketplace. Proceedings from the Summit on Seeds and Breeds in the 21st Century, Washington DC, USA.

Herbert D, Alban C, Cole DJ, Pallett KE, Harwood JL. 1994. Characteristics of two forms of acetyl-CoA carboxylase from maize leaves. Biochemical Society Transactions 22: 261S.

Hibbard KA, Meehl GA, Cox PM, Friedlingstein P. 2007. A strategy for climate change stabilization experiments. Earth and Space Science 88: 1-3.

Hixson SM, Arts MT. 2016. Climate warming is predicted to reduce omega-3, long-chain, polyunsaturated fatty acid production in phytoplankton. Global Change Biology 22: 2744-2755.

Hoffman DR, Theuer RC, Castaneda YS, Wheaton DH, Bosworth RG, O'Connor AR, Morale SE, Wiedermann LE, Birch EE. 2004. Human nutrition and metabolism maturation of visual acuity is accelerated in breast-fed term infants fed baby food containing DHA-enriched egg yolk. American Society for Nutritional Sciences 134: 2307-2313.

Holman RT. 1971. Essential fatty acid deficiency. Progress in the Chemistry of Fats and other Lipids 9: 275-348.

Holtby LB, Newcombe CP. 1982. A preliminary analysis of logging related temperature changes in Carnation. Pacific Biological Station, Nanaimo, B.C.

Honfo FG, Akissoe N, Linnemann AR, Soumanou M, Van Boekel MAJS. 2014. Nutritional composition of shea products and chemical properties of shea butter: A review. Critical Reviews of Food Science Nutrition 54: 673-686.

Howes NL, Bekhit AEDA, Burritt DJ, Campbell AW. 2015. Opportunities and implications of pasturebased lamb fattening to enhance the long-chain fatty acid composition in meat. Comprehensive Reviews in Food Science and Food Safety 14: 22-36.

Hugly S, Somerville C. 1992. A role for membrane lipid polyunsaturation in chloroplast biogenesis at low temperature. Plant Physiology 99: 197-202.

Iba K. 2002. Acclimative response to temperature stress in higher plants: Approaches of gene engineering for temperature tolerance. Annual Reviews in Plant Biology 53: 225-245. 
Idso SB, Kimball BA, Anderson MG, Mauney JR. 1987. Effects of atmospheric $\mathrm{CO}_{2}$ enrichment on plant growth: The interactive role of air temperature. Agriculture, Ecosystems and Environment 20: 110.

IPCC. 2014. Core Writing Team, Pachauri RK, Meyer LA. Climate Change 2014: Synthesis Report. Contribution of Working Groups I, II and III to the Fifth Assessment Report of the Intergovernmental Panel on Climate Change. IPCC, Geneva, Switzerland.

Iverson SJ. 2009. Tracing Aquatic Food Webs Using Fatty Acids: From Qualitative Indicators to Quantitative Determination. In: Kainz M., Brett M., Arts M. (eds) Lipids in Aquatic Ecosystems. Springer, New York, NY, 237-255.

Jafari A, Naseri H. 2007. Genetic variation and correlation among yield and quality traits in cocksfoot (Dactylis glomerata L.). Journal of Agricultural Science 145: 599-610.

Janben HJ, Steinbüchel A. 2014. Fatty acid synthesis in Escherichia coli and its applications towards the production of fatty acid based biofuels. Biotechnology for Biofuels 7: 7.

Jasuja N, Jain S, Joshi SC. 2010. Microbial production of docosahexaenoic acid (n-3 PUFA) and their role in human health. Asian Journal of Pharmaceutical and Clinical Research 3: 83-87.

Jiang Y, Huang B. 2014. Drought and heat stress injury to two cool-season turfgrasses in relation to antioxidant metabolism and lipid peroxidation. Crop Science 41: 436-442.

Johansson A, Laine T, Linna MM, Kallio H. 2000. Variability in oil content and fatty acid composition in wild northern currants. European Food Research and Technology 211: 277-283.

Jouhet J, Maréchal E, Block MA. 2007. Glycerolipid transfer for the building of membranes in plant cells. Progressive Lipid Research 46: 37-55.

Julier B, Huyghe C. 1997. Effect of growth and cultivar on alfalfa digestibility in a multi-site trial. Agronomie 17: 481-489.

Jung HG, Vogel KP. 1986. Influence of lignin on digestibility of forage cell wall material. Journal of Animal Science 62: 1703-1712. 
Junttila O, Svenning MM, Solheim B. 1990. Effects of temperature and photoperiod on vegetative growth of white clover (Trifolium repens) ecotypes. Physiologia Plantarum 79: 427-434.

Kabeya N, Fonseca MM, Ferrier DE, Navarro JC, Bay LK, Francis DS, Tocher DR, Castro LF, Monroig Ó. 2018. Genes for de novo biosynthesis of omega-3 polyunsaturated fatty acids are widespread in animals. Science advances 4: 1-8.

Kainz M, Telmer K, Mazumder A. 2006. Bioaccumulation patterns of methyl mercury and essential fatty acids in lacustrine planktonic food webs and fish. Science of the Total Environment 368: 271-282.

Karl TR, Knight RW, Plummer N. 1995. Trends in high-frequency climate variability in the twentieth century. Letters to Nature 377: 217-220.

Khan NA, Cone JW, Fievez V, Hendriks WH. 2012. Causes of variation in fatty acid content and composition in grass and maize silages. Animal Feed Science and Technology 174: 36-45.

Kilcher MR, Troelsen JE. 1973. Contribution and nutritive value of the major plant components of oats through progressive stages of development. Canadian Journal of Plant Science 53: 251-256.

Kilcher MR. 1981. Plant development, stage of maturity and nutrient composition. Journal of Range Management 34: 363-364.

Krauss RM, Eckel RH, Howard B, Appel LJ, Daniels SR, Deckelbaum RJ, Erdman JW, Kris-Etherton P, Goldberg IJ, Kotchen TA et al. 2000. AHA dietary guidelines. Circulation 120: 2284-2299.

Kris-Etherton PM, Taylor DS, Yu-Poth S, Huth P, Moriarty K, Fishell V, Hargrove RL, Zhao G, Etherton TD. 2000. Polyunsaturated fatty acids in the food chain in the United States. American Journal of Clinical Nutrition 71, 179S-188S.

Król B, Paszko T. 2017. Harvest date as a factor affecting crop yield, oil content and fatty acid composition of the seeds of calendula (Calendula officinalis L.) cultivars. Industrial Crops and Products 97: 242-251.

Ledgard SF, Steele KW. 1992. Biological nitrogen fixation in mixed legume/grass pastures. Plant and Soil 141: 137-153. 
Lee BK, Kim KY, Jung WJ, Avice JC, Ourry A, Kim TH. 2007. Peroxidases and lignification in relation to the intensity of water-deficit stress in white clover (Trifolium repens L .). Journal of Experimental Botany 58: 1271-1279.

Li Y, Kang JX, Leaf A. 1997. Differential effects of various eicosanoids on the production or prevention of arrhythmias in cultured neonatal rat cardiac myocytes. Prostaglandins 54: 511-530.

Li Q, Shen W, Zheng Q, Fowler D B, Zou J. 2016. Adjustments of lipid pathways in plant adaptation to temperature stress. Plant Signalling and Behaviour 11: e1058461.

Lindeman RL. 1942. The trophic-dynamic aspect of ecology. Ecology 23: 399-417.

Liu K. 1994. Preparation of fatty acid methyl esters for gas-chromatographic analysis of lipids in biological materials. Journal of the American Oil Chemists' Society 71: 1179-1187.

Liu X, Huang B. 2003. Root physiological factors involved in cool-season grass response to high soil temperature. Environmental and Experimental Botany 53: 233-245.

Liu X, Huang, B. 2004. Changes in fatty acid composition and saturation in leaves and roots of creeping bentgrass exposed to high soil temperature. Journal of the American Society of Horticultural Science 129: 795-801.

Liu YF, Li QT, Lu X, Song QX, Lam SM, Zhang WK, Ma B, Lin Q, Man WQ, Du WG et al. 2014. Soybean GmMYB73 promotes lipid accumulation in transgenic plants. BMC Plant Biology 14: 73.

Lock AL, Bauman DE. 2004. Modifying milk fat composition of dairy cows to enhance fatty acids beneficial to human health. Lipids 39: 1197-1206.

Los DA, Murata N. 1998. Structure and expression of fatty acid desaturases. Biochimica et Biophysica Acta 1394: 3-15.

Los DA, Mironov KS, Allakhverdiev SI. 2013. Regulatory role of membrane fluidity in gene expression and physiological functions. Photosynthesis Research 116: 489-509.

Lough JM. 1995. Temperature variations in a tropical-subtropical environment: Queensland, Australia, 1910-1987. International Journal of Climatology 15: 77-95 
Lourenco M, Van Ranst G, Vlaeminck B, De Smet S, Fievez V. 2008. Influence of different dietary forages on the fatty acid composition of rumen digesta as well as ruminant meat and milk. Animal Feed Science and Technology 145: 418-437.

Loveys BR, Scheurwater I, Pons TL, Fitter AH, Atkin OK. 2002. Growth temperature influences the underlying components of relative growth rate: An investigation using inherently FAt- and slowgrowing plant species. Plant, Cell and Environment 25: 975-987.

Luginbuehl LH, Menard GN, Kurup S, Van Erp H, Radhakrishnan GV, Breakspear A, Oldroyd GD, Eastmond PJ. 2017. Science aan-0081.

Lung SC, Weselake RJ. 2006. Diacylglycerol acyltransferase: A key mediator of plant triacylglycerol synthesis. Lipids 41: 1073-1088.

Lyons J, Thimble SW. 2001. Grass versus trees: Managing riparian areas to benefit streams of Central North America. Journal of the American Water Resources Association 36: 919-930.

Majak W, Hall JW, McCaughey WP. 1994. Pasture management strategies for reducing the risk legume bloat in cattle. Journal of Animal Science 73: 1493-1498.

Makarenko SP, Konstantinov YM, Khotimchenko SV, Konenkina TA, Arziev AS. 2003. Fatty acid composition of mitochondrial membrane lipids in cultivated (Zea mays) and wild (Elymus sibiricus) grasses. Russian Journal of Plant Physiology 50: 487-491.

Malainey ME, Przybylski R, Sherriff BL. 1999. The fatty acid composition of native food plants and animals of western Canada. Journal of Archaeological Science 26: 83-94.

Manning R. 2006. Fatty acid composition of pollen and the effect of two dominant fatty acids (linoleic and oleic) in pollen and flour diets on longevity and nutritional composition of honey bees (Apis mellifera). $\mathrm{PhD}$ thesis, Murdoch University.

Marchand L, Pelosi C, Gonzalez-Centeno MR, Maillard A, Ourry A, Galland W, Teissedre PL, Bessoule JJ, Mongrand S, Morvan-Bertrand A et al. 2016. Trace element bioavailability, yield and seed quality of rapeseed (Brassica napus L.) modulated by biochar incorporation into a contaminated technosol. Chemosphere 156: 150-162. 
Marcum Kentucky bluegrass. 1998. Cell membrane thermostability and whole-plant heat tolerance of Kentucky bluegrass. Crop Science 38:1214+.

Marzetz V, Koussoroplis A, Martin-Creuzburg D, Striebel M, Wacker A. 2017. Linking primary producer diversity and food quality effects on herbivores: A biochemical perspective. Scientific Reports 7: $1-9$.

Martin CE, Hiramitsu K, Kitajima Y, Nozawa Y, Skriver L, Thompson GA. 2008. Molecular control of membrane properties during temperature acclimation. Fatty acid desaturase regulation of membrane fluidity in acclimating Tetrahymena cells. Biochemistry 15: 5218-5227.

Mattson FH, Volpenhein RA. 1963. The specific distribution of unsaturated fatty acids in the triglycerides of plants. Journal of Lipid Research 4: 392-396.

McCartney D, Horton PR. 1997. Canada's forage resources. International Grasslands Conference 1-10.

McConn M, Browse J. 1996. The critical requirement for linolenic acid is pollen development, not photosynthesis, in an Arabidopsis mutant. The Plant Cell 8: 403-416.

Mei C, Michaud M, Cussac M, Albrieux C, Gros V, Marechal E, Block MA, Jouhet J, Rebeille F. 2015. Levels of polyunsaturated fatty acids correlate with growth rate in plant cell cultures. Scientific Reports 5: 1-9.

Meluchova B, Blasko J, Kubinec R, Gorova R, Dubravska J, Margetin M, Sojak L. 2008. Seasonal variations in fatty acid composition of pasture forage plants and CLA content in ewe milk fat. Small Ruminant Research 78: 56-65.

Menard CR, Goodman KJ, Corso TN, Brenna JT, Cunnane SC. 1998. Recycling of carbon into lipids synthesized de novo is a quantitatively important pathway of alpha-[U-13C] linolenate utilization in the developing rat brain. Journal of Neurochemistry 71: 2151-2158.

Menard GN, Moreno JM, Bryant FM, Munoz-Azcarate O, Kelly AA, Hassani-Pak K, Kurup S, Eastmond PJ. 2017. Genome wide analysis of fatty acid desaturation and its response to temperature. Plant Physiology 173: 1594-1605.

Merila J, Hendry AP. 2013. Climate change, adaptation, and phenotypic plasticity: The problem and the evidence. Evolutionary Applications 7: 1-14. 
Millar AA, Smith MA, Kunst L. 2000. All fatty acids are not equal: Discrimination in plant membrane lipids. Trends in Plant Science 5: 95-101.

Milligan LA, Bazinet RP. 2008. Evolutionary modifications of human milk composition: Evidence from long-chain polyunsaturated fatty acid composition of anthropoid milks. Journal of Human Evolution 55: 1086-1095.

Mir PS, Bittman S, Hunt D, Entz T, Yip B. 2006. Lipid content and fatty acid composition of grasses sampled on different dates through the early part of the growing season. Canadian Journal of Animal Science 86: 279-290.

Mishra S, Tyagi A, Singh IV, Sangwan RS. 2006. Changes in lipid profile during growth and senescence of Catharanthus roseus leaf. Brazilian Journal of Plant Physiology 18: 447-454.

Mitchell KJ, Lucanus R. 2012. Growth of pasture species under controlled environment. New Zealand of Agricultural Research 5: 135-144.

Moore KJ, Moser LE, Vogel KP, Waller SS, Johnson BE, Pedersen JF. 1991. Describing and quantifying growth stages of perennial forage grasses. Agronomy Journal 83: 1073-1077.

Morgan CA, Noble RC, Cocchi M, McCartney R. 1992. Manipulation of the fatty acid composition of pig meat lipids by dietary means. Science of Food and Agriculture 58: 357-368.

Moss RH, Edmonds JA, Hibbard KA, Manning MR, Rose SK, Van Vurren DP, Carter TR, Emori S, Kainuma M, Kram T et al. 2010. The next generation of scenarios for climate change research and assessment. Nature 463: 747-756.

Moyo B, Masika PJ, Hugo A, Muchenje V. 2011. Nutritional characterization of Moringa (Moringa oleifera Lam.) leaves. African Journal of Biotechnology 10: 12925-12933.

Mozaffarian D, Wu JHY. 2011. Omega-3 fatty acids and cardiovascular disease: Effects on risk factors, molecular pathways, and clinical events. Journal of the American College of Cardiology 58: 2047-2067.

Muhly TB, Hebblewhite M, Paton D, Pitt JA, Boyce MS, Musiani M. 2013. Humans strengthen bottomup effects and weaken trophic cascades in a terrestrial food web. PLoS One 8: e64311. 
Muller-Navarra DC, Brett MT, Liston AM, Goldman CR. 2000. A highly unsaturated fatty acid predicts carbon transfer between primary producers and consumers. Nature 403: 4-7.

Murakami Y, Tsuyama M, Kobayashi Y, Kodama H, Iba K. 2000. Trienoic fatty acids and plant tolerance of high temperature. Science 287: 476-479.

Murata N, Los DA. 1997. Membrane fluidity and temperature perception. Plant Physiology 2: 875-879.

Murphy AH. 1970. Predicted forage yield based on fall precipitation in California annual grasslands. Journal of Range Management 1:363-5.

Murphy DJ, Harwood JL, Lee KA, Roberto F, Stumpf PK, St. John JB. 1985. Differential responses of a range of photosynthetic tissues to a substituted pyridazinone, Sandoz 9785. Specific effects on fatty acid desaturation. Phytochemistry 24: 1923-1929.

Murthy M, Hamilton J, Greiner RS, Moriguchi T, Salem N, Kim HY. 2002. Differential effects of n-3 fatty acid deficiency on phospholipid molecular species composition in the rat hippocampus. Journal of Lipid Science 43: 611-617.

Narayanan S, Tamura PJ, Roth MR, Vara Prasad PV, Welti R. 2016. Wheat leaf lipids during heat stress: I. High day and night temperatures result in major lipid alterations. Plant Cell Environment 39: 787-803.

Nelson DR, Schuler MA, Paquette SM, Werck-Reichhart D, Bak S. 2004. Comparative genomics of rice and Arabidopsis. Analysis of 727 cytochrome P450 genes and pseudogenes from a monocot and a dicot. Genome Analysis 135: 756-772.

Neuringer M, Connor WE, Lin DONS, Barstad L, Luck S. 1986. Biochemical and functional effects of prenatal and postnatal w3 fatty acid deficiency on retina and brain in rhesus monkeys. Proceedings of the National Academy of Sciences of the United States of America 83: 4021-4025.

Nguyen T, Aparicio M, Saleh MA, McPhee DJ. 2015. Accurate mass GC/LC-quadrupole time of flight mass spectrometry analysis of fatty acids and triacylglycerols of spicy fruits from the Apiaceae family. Molecules 20: 21421-21432. 
Nichols PD, Guckert JB, White DC. 1986. Determination of monounsaturated fatty acid double-bond position and geometry for microbial monocultures and complex consortia by capillary GC-MS of their dimethyl disulphide adducts. Journal of Microbiological Methods 5: 49-55.

Nousiainen J, Rinne M, Hellämäki M, Huhtanen P. 2003. Prediction of the digestibility of the primary growth of grass silages harvested at different stages of maturity from chemical composition and pepsin-cellulase solubility. Animal Feed Science and Technology 103: 97-111.

Nozawa Y. 2011. Adaptive regulation of membrane lipids and fluidity during thermal acclimation in Tetrahymena. Proceedings of the Japan Academy 87, 450-462.

Ohlrogge J, Browse J. 1995. Lipid biosynthesis. Plant Cell 7: 957-70.

Ohlrogge JB, Jaworski JG. 1997. Regulation of fatty acid synthesis. Annual Reviews of Plant Physiology and Plant Molecular Biology 48: 109-136.

Oliveira M, Jarcilene B, Antonio S, Morais F. 2014. Seed oil content and fatty acid composition from different populations of Calotropis procera (Aiton) W. T. Aiton (Apocynaceae). Jounrla of the American Oil Chemical Society 91: 1433-1441.

Onemli F. 2012. Impact of climate change on oil fatty acid composition of peanut (Arachis hypogaea 1.) in three market classes. Chilean Journal of Agricultural Research. 72: 483-489.

Ördög V, Stirk WA, Balint P, Aremu AO, Okem A, Lovasz C, Molnar Z, Staden J. 2016. Effect of temperature and nitrogen concentration on lipid productivity and fatty acid composition in three Chlorella strains. Algal Research 16: 141-149.

Orhan I, Deliorman-Orhan D, Özçelik B. 2009. Antiviral activity and cytotoxicity of the lipophilic extracts of various edible plants and their fatty acids. Food Chemistry 115: 701-705.

Ouellet M, Emond V, Chen CT, Julien C, Bourasset F, Oddo S, LaFerla F, Bazinet RP, Calon F. 2009. Diffusion of docosahexaenoic and eicosapentaenoic acids through the blood-brain barrier: An in situ cerebral perfusion study. Neurochemistry International 55: 476-482.

Owens FN, Secrist DS, Hill WJ, Gill DR. 1998. Acidosis in cattle: A review. Journal of Animal Science 76: $275-286$. 
Özcan T. 2008. Analysis of the total oil and fatty acid composition of seeds of some Boraginaceae taxa from Turkey. Plant Systems Evolution 274: 143-153.

Page RA, Okada S, Harwood JL. 1994. Acetyl-CoA carboxylase exerts strong flux control over lipid synthesis in plants. Biochimica et Biophysica Acta 1210: 369-372.

Pagell M, Krumwiede DW, Sheu C. 2007. Efficacy of environmental and supplier relationship investments - moderating effects of external environment. International Journal of Production Research 45: 2005-2028.

Parton WJ, Logan JA. 1981. A model for diurnal variation in soil and air temperature. Agricultural Meteorology 23: 205-216.

Pascual-Villalobos MJ, Alburquerque N. 1995. Genetic variation of a safflower germplasm collection grown as a winter crop in southern Spain. Euphytica 92: 327-332.

Pastenes C, Horton P. 1996. Effect of high temperature on photosynthesis in beans. Plant Physiology 112: $1245-1251$.

Peacock JM. 1975. Temperature and leaf growth in Lolium Perenne. Journal of Applied Ecology 12: 115123.

Pearcy RW. 1978. Effect of growth temperature on the fatty acid composition of the leaf lipids in Atriplex lentiformis (Torr.) Wats. Plant Physiology 61: 484-486.

Pernet F, Tremblay R, Comeau L, Guderley H. 2007. Temperature adaptation in two bivalve species from different thermal habitats: Energetics and remodelling of membrane lipids. Journal of Experimental Biology 210: 2999-3014.

Piironen V, Lindsay DG, Miettinen TA, Toivo J. Lampi A. 2000. Plant sterols: Biosynthesis, biological function and their importance to human nutrition. Journal of the Science of Food and Agriculture 80: 939-966.

Pike CS. 1982. Membrane lipid physical properties in annuals grown under contrasting thermal regimes. Plant Physiology 70: 1764-1766. 
Poire R, Wiese-klinkenberg A, Parent B, Mielewczik M, Schurr U, Tardieu F, Walter A. 2010. Diel timecourses of leaf growth in monocot and dicot species: Endogenous rhythms and temperature effects. Journal of Experimental Botany 61, 1751-1759.

Ponnampalam EN, Mann NJ, Sinclair AJ. 2006. Effect of feeding systems on omega-3 fatty acids, conjugated linoleic acid and trans fatty acids in Australian beef cuts: Potential impact on human health. Asia Pacific Journal of Clinical Nutrition 15: 21-29.

Post-Beittenmiller D, Roughan G, Ohlrogge JB. 1992. Regulation of plant fatty acid biosynthesis. Plant Physiology 100: 923-930.

Power ME. 1992. Top-down and bottom-up forces in food webs: Do plants have primacy? Ecology 73: 733-746.

Prada F, Ayala-Diaz M, Delgado W, Ruiz-Romero R, Romero M. 2011. Effect of fruit ripening on content and chemical composition of oil from three oil palm cultivars (Elaeis guineensis Jacq.) grown in Colombia. Agricultural and Food Chemistry 59: 10136-10142.

Quinn PJ, Williams WP. 1983. The structural role of lipids in photosynthetic membranes. Biochimica et Biophysica Acta 737: 223-266.

Ramezanzadeh FM, Rao RM, Prinyawiwatkul W, Marshall WE, Windhauser M. 2000. Effects of microwave heat, packaging, and storage temperature on fatty acid and proximate compositions in rice bran. Journal of Agricultural Food Chemistry 48: 464-467.

Rao JS, Ertley RN, DeMar JC, Rapoport SI, Bazinet RP, Lee HJ. 2007. Dietary n-3 PUFA deprivation alters expression of enzymes of the arachidonic and docosahexaenoic acid cascades in rat frontal cortex. Molecular Psychiatry 12: 151-157.

Rice KJ, Blackt RA, Radamakert G, Evans RD. 1992. Photosynthesis, growth, and biomass allocation in habitat ecotypes of cheatgrass (Bromus tectorum). Functional Ecology 6: 32-40.

Richards CL, Bossdorf O, Muth NZ, Gurevitch J, Pigliucci M. 2006. Jack of all trades, master of some? On the role of phenotypic plasticity in plant invasions. Ecology Letters 9: 981-993.

Robinson J. 2002. Pasture perfect. Mother Earth News 191: 46-51. 
Roessler PG. 1990. Environmental control of glycerolipid metabolism in microalgae: Commercial implications and future research directions. Journal of Phycology 26: 93-399.

Rozema J, Bjorn LO, Bornman JF, Gaberscik A, Hader DP, Trost T, Germ M, Klisch M, Groniger A, Sinha RP et al. 2002. The role of UV-B radiation in aquatic and terrestrial ecosystems - an experimental and functional analysis of the evolution of UV-absorbing compounds. Journal of Photochemistry and Photobiology 66: 2-12.

Russelle MP, Entz MH, Franzluebbers AJ. 2007. Reconsidering integrated crop-livestock systems in North America. Agronomy Journal 99: 325-334.

Saleem AM, Mirza N. 2009. Effect of diverse ecological conditions on biomass production of Themeda triandra [Kangaroo grass] at various growth stages. African Journal of Biotechnology 8: 12331237.

Sanders TAB. 2000. Polyunsaturated fatty acids in the food chain in Europe. American Journal of Clinical Nutrition 71: 176-178.

Sanders TAB. 2014. Protective effects of dietary PUFA against chronic disease: Evidence from epidemiological studies and intervention trials. Proceedings of the Nutrition Society 73: 73-79.

Santos MFG, Marmesat S, Brito ES, Alves RE, Dobarganes MC. 2013. Major components in oils obtained from Amazonian palm fruits. Grasas y Aceites 64: 328-334.

Santos JEP, Bilby TR, Thatcher WW, Staples CR, Silvestre FT. 2008. Long chain fatty acids of diet as factors influencing reproduction in cattle. Reproduction in Domestic Animals 43: 23-30.

Sanyal A, Decocq G. 2016. Adaptive evolution of seed oil content in angiosperms: Accounting for the global patterns of seed oils. BMC Evolutionary Biology 16: 187.

Sargent J, Bell G, McEvoy L, Tocher D, Estevez A. 1999. Recent developments in the essential fatty acid nutrition of fish. Aquaculture 177: 191-199.

Saunders LP, Sen S, Wilkinson BJ, Gatto C. 2016. Insights into the mechanism of homeoviscous adaptation to low temperature in branched-chain fatty acid-containing bacteria through modeling FabH kinetics from the foodborne pathogen listeria monocytogenes. Frontiers in Microbiology 7: $1-8$. 
Scollan N, Nuernberg K, Dannenberger D, Richardson I, Moloney A. 2006. Innovations in beef production systems that enhance the nutritional and health value of beef lipids and their relationship with meat quality. Meat Science 74: 17-33.

Shaw MR, Zavaleta ES, Chiariello NR, Cleland EE, Mooney HA, Field CB. 2002. Grassland responses to global environmental changes suppressed by elevated CO2. Science 298: 1987-1990.

Sheppard AJ, Iverson JL. 1975. Esterification of fatty acids for gas-liquid chromatographic analysis. Journal of Chromatographic Science 13: 448-452.

Shimojima M, Ohta H. 2011. Critical regulation of galactolipid synthesis controls membrane differentiation and remodeling in distinct plant organs and following environmental changes. Progressive Lipid Research 50: 258-266.

Silva SI, Oliveira AFM, Negri G, Salatino A. 2014. Seed oils of Euphorbiaceae from the Caatinga, a Brazilian tropical dry forest. Biomass and Bioenergy 69: 124-134.

Simopoulos A. 1991. Omega-3 fatty acids in health and disease and in growth and development. American Journal of Clinical Nutrition 54: 438-63.

Sinensky M. 1974. Homeoviscous adaptation - A homeostatic process that regulates the viscosity of membrane lipids in Escherichia coli. Proceedings of the National Academy of Sciences of the United States of America 71: 522-525 (1974).

Singer P, Theilla M, Fisher H, Gibstein L, Grozovski E, Cohen J. 2006. Benefit of an enteral diet enriched with eicosapentaenoic acid and gamma-linolenic acid in ventilated patients with acute lung injury. Critical Care Medicine 34: 1033-1038.

Smith M, Lawrence J. 2008. Organic, natural and grass-fed beef: Profitability and constraints to production in the Midwestern United States. Competitive Grant Report M2005-30. Leopold Center Progress Report. 17: 57-59.

Smolenska GA, Kuiper PJC. 1977. Effect of low temperature upon lipid and fatty acid composition of roots and leaves of winter rape plants. Physiologia Plantarum 41: 29-35.

Sreenivasulu N, Wobus U. 2013. Seed-development programs: A systems biology - based comparison between dicots and monocots. Annual Reviews in Plant Biology 64: 189-217. 
Stark AH, Crawford MA, Reifen R. 2008. Update on alpha-linolenic acid. Nutrition Reviews 66: 326332.

Steeneveld GJ, Koopmans S, Heusinkveld BG, Theeuwes NE. 2014. Landscape and urban planning refreshing the role of open water surfaces on mitigating the maximum urban heat island effect. Landscaping and Urban Planning 121: 92-96.

Sulc RM, Tracy BF. 2007. Integrated crop-livestock systems in the U.S. corn belt. Agronomy Journal 99: $335-345$.

Susanto E, Fahmi AS, Abe M, Hosokawa M, Miyashita K. 2016. Lipids, fatty acids, and fucoxanthin content from temperate and tropical brown seaweeds. Aquatic Procedia 7: 66-75.

Sultan SE. 1995. Phentypic plasticity and plant adaptation. Acta Botanica Neerlandica 44: 363-383.

Sun CX, Gao XX, Li MQ, Fu JQ, Zhang YL. 2016. Plastic responses in the metabolome and functional traits of maize plants to temperature variations. Plant Biology 18: 249-261.

Surette ME. 2013. Dietary omega-3 PUFA and health: Stearidonic acid-containing seed oils as effective and sustainable alternatives to traditional marine oils. Molecular Nutrition and Food Research 00: $1-12$.

Szymanski J, Brotman Y, Willmitzer L, Cuadros-Inostroza A. 2014. Linking gene expression and membrane lipid composition of Arabidopsis. Plant Cell 26: 915-928.

Teixeira RS, Rocha perennial ryegrass, Polnini HC, Brandao MAF, Chaves MGAM, Raposo NRB. 2012. Mushroom tyrosinase inhibitory activity and major fatty acid constituents of Amazonian native flora oils. Brazilian Journal of Pharmaceutical Sciences 48: 399-404.

Terry RA, Tilley JMA. 1964. The digestibility of the leaves and stems of perennial ryegrass, cocksfoot, timothy, tall fescue, lucerne and sainfoin, as measured by an in vitro procedure. Grass and Forage Science 19: 363-373.

Terzaghi WB. 1989. Manipulating membrane fatty acid compositions of whole plants with tween-fatty acid esters. Plant Physiology 91: 203-212. 
Thelen JJ, Ohlrogge JB. 2002. Metabolic engineering of fatty acid biosynthesis in plants. Metabolic Engineering 4: 12-21.

Thomas, H. 1984. Effects of drought on growth and competitive ability of perennial ryegrass and white clover. Journal of Applied Ecology 21:591-602.

Thomas MC, Mitchell TW, Harman DG, Deeley JM, Murphy RC, Blanksby SJ. 2007. Elucidation of double bond position in unsaturated lipids by ozone electrospray ionization mass spectrometry. Analytical Chemistry 79: 5013-5022.

Tremolieres A, Dubacq JP, Drapier D. 1982. Unsaturated fatty acids in maturing seeds of sunflower and rape: Regulation by temperature and light intensity. Phytochemistry 21: 41-45.

Tubiello FN, Soussana J, Howden SM. 2007. Crop and pasture response to climate change. Proceedings of the National Academy of Sciences of the United States of America 104: 19686-19690.

Upchurch RG. 2008. Fatty acid unsaturation, mobilization, and regulation in the response of plants to stress. Biotechnology Letters 30: 967-977.

Urquiaga SK, Cruz HS, Boddey RM. 1992. Contribution of nitrogen fixation to sugar cane: Nitrogen-15 and nitrogen-balance estimates. Soil Science Society of America Journal 56: 105-114.

Vásquez-Ocmín PG, Freitas Alvarado L, Sotero Solís V, Paván Torres R, Mancini-Filho J. 2010.

Chemical characterization and oxidative stability of the oils from three morphotypes of Mauritia flexuosa L.f, from the Peruvian Amazon. Grasas y Aceites 61: 390-397.

Vioque J, Pastor JE, Vioque E. 1994. Estudio de la composicion en acidos grasos del aceite de las semillas en algunas plantas silverstres espanolas. Grasas y Aceites 45: 161-163.

Vos J, van der Putten PEL, Birch CJ. 2005. Effect of nitrogen supply on leaf appearance, leaf growth, leaf nitrogen economy and photosynthetic capacity in maize (Zea mays L.). Field Crops Research 93: 64-73.

Wand SJE, Midgley GF, Jones MH, Curtis PS. 1999. Responses of wild C4 and C3 grass (Poaceae) species to elevated atmospheric $\mathrm{CO}_{2}$ concentration: A meta-analytic test of current theories and perceptions. Global Change Biology 5: 723-741. 
Wang W, Vinocur B, Altman A. 2003. Plant responses to drought, salinity and extreme temperatures: Towards genetic engineering for stress tolerance. Planta 218: 1-14.

Wang Z, Huang B. 2004. Physiological recovery of Kentucky bluegrass from simultaneous drought and heat stress. Crop Science 41: 1729-1736.

Wardle DA, Barker GM, Bonner KI, Nicholson KS. 1998. Can comparative approached based on plant ecophysiological traits predict the nature of biotic interactions and individual plant species effects in ecosystems? Journal of Ecology 86: 405-420.

Wardle DA, Bardgett RD, Klironomos JN, Setala H, van der Putten WH, Wall DH. 2004. Ecological linkages between aboveground and belowground biota. Science 304, 1629-1633.

Warren FJ, Lemmen DS. 2014. Canada in a Changing Climate: Sector Perspectives on Impacts and Adaptation. Government of Canada, Ottawa, ON, Canada.

Wataru Y, Hikosaka K, Way DA. 2014. Temperature response of photosynthesis in $\mathrm{C}_{3}, \mathrm{C}_{4}$, and CAM plants: Temperature acclimation and temperature adaptation. Photosyntheis Research 119: 101117.

Weather Spark. 2018. The Typical Weather Anywhere on Earth - Weather Spark. Retrieved from https://weatherspark.com/

Wilson JM, Crawford RMM. 1974. The acclimatization of plants to chilling temperatures in relation to the fatty acid composition of leaf polar lipids. New Phytologist 73: 805-820.

Woledge J, Jewess OR. 1969. The Effect of temperature during growth on the subsequent rate of photosynthesis in leaves of tall fescue (Festuca arundinacea Schreb.). Annals of Botany 33: 897913.

Wood JD, Enser M, Fisher AV, Nute GR, Sheard perennial ryegrass, Richardson RI, Hughes SI, Whittington FM. 2008. Fat deposition, fatty acid composition and meat quality: A review. Meat Science 78: 343-358.

Wu J, Hwang IT, Hatzios KK. 2000. Effects of chloroacetanilide herbicides on membrane fatty acid desaturation and lipid composition in rice, maize, and sorghum. Pesticide Biochemistry and Physiology 66: 161-169. 
Xu S, Li J, Zhang X, Wei H, Cui L. 2006. Effects of heat acclimation pre-treatment on changes of membrane lipid peroxidation, antioxidant metabolites, and ultrastructure of chloroplasts in two cool-season turfgrass species under heat stress. Environmental and Experimental Botany 56: 274285.

Yang Y, Jin Z, Jin Q, Dong M. 2015. Isolation and fatty acid analysis of lipid producing endophytic fungi from wild Chinese Torreya Grandis. Microbiology 84, 710-716.

Yoshida S, Uemura M. 1984. Protein and lipid compositions of isolated plasma membranes from orchard grass (Dactylis glomerata L.) and changes during cold acclimation. Plant Physiology 75: 31-37.

Yoshida K, Hashimoto M, Hori R, Adachi T, Okuyama H, Orikasa Y, Nagamine T, Shimizu S, Ueno A, Morita N. 2016. Bacterial long-chain polyunsaturated fatty acids: their biosynthetic genes, functions, and practical use. Marine Drugs 14: 94.

Yu GS, Steinkirchner TM, Rao GA, Larkin EC. 1986. Effect of prenatal iron deficiency on myelination in rat pups. American Journal of Pathology 125: 620-624.

Yurchenko O, Shockey JM, Gidda SK, Silver MI, Chapman KD, Mullen RT, Dyer JM. 2017. Engineering the production of conjugated fatty acids in Arabidopsis thaliana leaves. Plant Biotechnology Journal 15: 1010-1023.

Zahran HH. 1999. Rhizobium-legume symbiosis and nitrogen fixation under severe conditions and in an arid climate. Microbiology and Molecular Biology Reviews 63: 968-989.

Zhang M, Lee X, Yu G, Han S, Wang H, Yan J, Zhang Y, Li Y, Ohta T, Hirano T et al. 2014. Response of surface air temperature to small-scale land clearing across latitudes. Environmental Research Letters 9: 1-7.

Zheng H, Rowland O, Kunst L. 2005. Disruptions of the Arabidopsis enoyl-CoA reductase gene reveal an essential role for very-long-chain fatty acid synthesis in cell expansion during plant morphogenesis. The Plant Cell 17: 1467-1481

Zheng G, Tian B, Zhang F, Tao F, Li W. 2011. Plant adaptation to frequent alterations between high and low temperatures: remodelling of membrane lipids and maintenance of unsaturation levels. Plant, Cell and Environment 34: 1431-1442. 